\title{
Western Africa
}

\section{Container Terminals Concessions - Making the Most of Ports in West Africa}

June $16^{\text {th }}, 2017$

GTI08

AFRICA

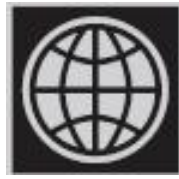

Standard Disclaimer:

This volume is a product of the staff of the International Bank for Reconstruction and Development/ The World Bank. The findings, interpretations, and conclusions expressed in this paper do not necessarily reflect the views of the Executive Directors of The World Bank or the governments they represent. The World Bank does not guarantee the accuracy of the data included in this work. The boundaries, colors, denominations, and other information shown on any map in this work do not imply any judgment on the part of The World Bank concerning the legal status of any territory or the endorsement or acceptance of such boundaries. 
Copyright Statement:

The material in this publication is copyrighted. Copying and/or transmitting portions or all of this work without permission may be a violation of applicable law. The International Bank for Reconstruction and Development/ The World Bank encourages dissemination of its work and will normally grant permission to reproduce portions of the work promptly.

For permission to photocopy or reprint any part of this work, please send a request with complete information to the Copyright Clearance Center, Inc., 222 Rosewood Drive, Danvers, MA 01923, USA, telephone 978-750-8400, fax 978-750-4470, http://www.copyright.com/.

All other queries on rights and licenses, including subsidiary rights, should be addressed to the Office of the Publisher, The World Bank, 1818 H Street NW, Washington, DC 20433, USA, fax 202-522-2422, e-mail pubrights@worldbank.org. 


\section{Acknowledgments}

This report is a collaborative effort of the Transport \& ICT and Trade \& Competitiveness Global Practices of the World Bank Group. Part of the work is based on a background report prepared by ECORYS (led by Marten van der Bossche, Khalid Bichou, Ibrahima Diong, Sophie Leeuwenburgh, Guillaume Remy, Wim De Rycke and Simme Veldman).

The report benefited tremendously from comments and inputs by Yann Alix (Foundation SEFACIL), Rachid Benmessaoud (Country Director, AFCW2), Bruno Bonansea (Cartographer), Colin Bruce (Senior Adviser, EXC), Charles Kunaka (Senior Trade Specialist, GTCTC), Martin Humphreys (Lead Transport Specialist, GTI01), Henry Des Longchamps (Senior Railways Specialist, GTI01), Gylfi Palsson (Lead Transport Specialist, GTI04), Pierre Pozzo di Borgo (Chief Industry Specialist, IFC) and Christophe Ian Twinn (Manager, CNGTR). Excellent comments were also received from Georgiana Pop (Senior Economist, GTCTC) and Martha Martinez Licetti (Lead Specialist, GTCTC).

Key findings of the report were disseminated at the $37^{\text {th }}$ Council Meeting organized by the Ports Management Association of West and Central Africa (PMAWCA) in Abidjan, in June 2015, as well as at a workshop jointly organized by the Africa Transport Policy Program (SSATP) and the Regional Economic Committees' Transport Coordination Committee (TCC) in December 2015 in Nairobi. The preliminary results were also presented at a World Bank Transport Forum session on May 28, 2015. The authors thank the participants and organizers of these fora, and in particular, the PMAWCA Secretary General Michael Luguje for the opportunity to share the findings of the Report.

Funding from the United Kingdom's Department for International Development under the Support to West Africa Regional Integration Program (SWARIP) window of the Multi-Donor Trust Fund for Trade and Development 2 supported by the governments of the Netherlands, Norway, Sweden, Switzerland, and the United Kingdom is gratefully acknowledged.

The main authors of the final report are Kavita Sethi (Senior Transport Economist, GTI04) and Olivier Hartmann (Senior Trade Facilitation Specialist, GTCTC), with contributions from a World Bank team comprising Antoine Coste (Economist, GTC07), Gözde Isik (Trade Economist, GTC13), Anne-Cecile Souhaid (Sr. Transport Specialist, GTI08) and Michel Audige (Consultant, GTI08). Gael Raballand, Senior Public Sector Specialist, Marc Juhel, Ports Advisor, Consultant, and Jan Hoffman (UNCTAD) peer reviewed the report. The entire team would like to express its gratitude to the peer reviewers all of whom provided invaluable comments and guidance in-between meetings and through the process. The team benefited as well from the support and guidance of JeanChristophe Maur (Senior Economist, GTC07), and Supee Teravaninthorn (Practice Manager, GTI01). Desta Woldeargey (Program Assistant, GTI01) provided excellent team support throughout the preparation and finalization of the report and William Shaw, Consultant, provided invaluable support in editing the report. 


\section{Abbreviations and acronyms}

$\begin{array}{ll}\text { AfDB } & \text { African Development Bank } \\ \text { APMT } & \text { A.P. Moller Terminals } \\ \text { BAL } & \text { Bolloré Logistics Limited } \\ \text { BOT } & \text { Build-operate-transfer } \\ \text { CMHI } & \text { China Merchant Holding International } \\ \text { CMA-CGM } & \text { Compagnie Maritime d'Affrètement - Compagnie Générale Maritime } \\ \text { DEA } & \text { Data Envelopment Analysis } \\ \text { EBITDA } & \text { Earnings Before Interest, Tax, Depreciation and Authorization } \\ \text { ECOWAS } & \text { Economic Community of West African States } \\ \text { ETE } & \text { End-to-End } \\ \text { GDP } & \text { Gross domestic product } \\ \text { GPHA } & \text { Ghana Ports and Harbors Authority } \\ \text { IFC } & \text { International Finance Cooperation } \\ \text { LCT } & \text { Lome Container Terminal } \\ \text { LPLE } & \text { Lekki Port LFTZ Enterprise } \\ \text { LSCI } & \text { Liner Shipping Connectivity Index } \\ \text { ICTSI } & \text { International Container Terminal Services } \\ \text { IMF } & \text { International Monetary Fund } \\ \text { MHC } & \text { Mobile Harbor Cranes } \\ \text { MPI } & \text { Malmquist Productivity Index } \\ \text { MPS } & \text { Meridian Port Services } \\ \text { MSC } & \text { Mediterranean Shipping Company } \\ \text { NPA } & \text { Nigeria Port Authority } \\ \end{array}$




\begin{tabular}{|c|c|}
\hline PCHS & Ports and Cargo Handling Services \\
\hline PMAWCA & Ports Management Association of West and Central Africa \\
\hline PPIAF & Public-Private Infrastructure Advisory Facility \\
\hline PEC & Pure efficiency change \\
\hline PPP & Public-Private Partnerships \\
\hline REC & Rregional Economic Communities \\
\hline RTG & Rubber-Tyred Gantry \\
\hline SEC & Scale Efficiency Change \\
\hline SETV & (Société d'Exploitation du Terminal de Vridi) \\
\hline SFA & Stochastic Frontier Analysis \\
\hline SSA & Sub-Saharan Africa \\
\hline STS & Ship to Shore Crane \\
\hline TEU & Twenty-foot Equivalent Units \\
\hline TICT & Tincan Island Container Terminal \\
\hline TIL & Terminal Investment Limited \\
\hline TOC & Terminal Operating Companies \\
\hline UEMOA & $\begin{array}{l}\text { West African Economic and Monetary Union (Union Economique et Monétaire } \\
\text { Ouest Africaine) }\end{array}$ \\
\hline UNCTAD & United Nations on Trade and Development \\
\hline USAID & United States Agency for International Development \\
\hline WBG & World Bank Group \\
\hline
\end{tabular}




\section{Table of Contents}

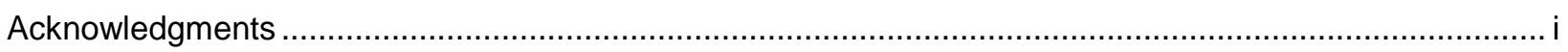

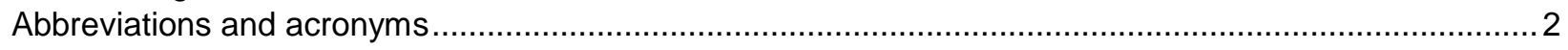

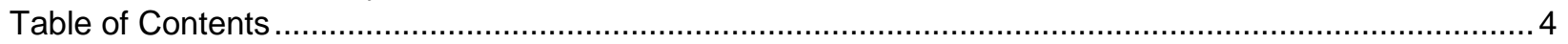

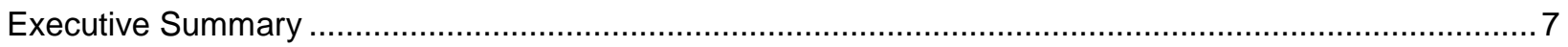

1. The West African Ports Landscape and Containerized Trade...................................................... 15

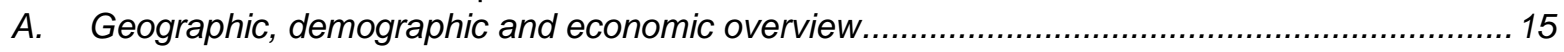

B. The development of the West African port sector ......................................................... 16

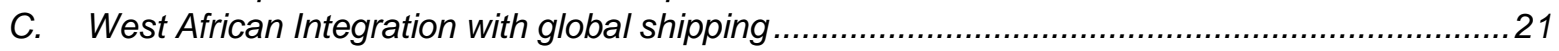

2. The Economics of the Port Sector and Implications for West Africa ...............................................25

A. Features and Economics of Natural Monopolies..........................................................25

B. Organization of the Port and Shipping Industry: Globally and in West Africa ...........................26

C. The "Naturally Monopolistic" Container Terminal Market of West Africa and competition for the

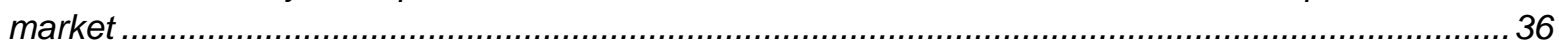

3. Institutional Reforms and the Governance of Container Terminal Concessions ...............................40

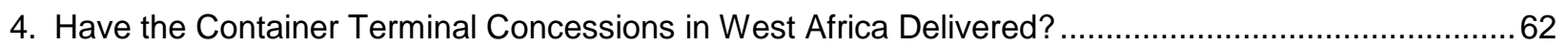

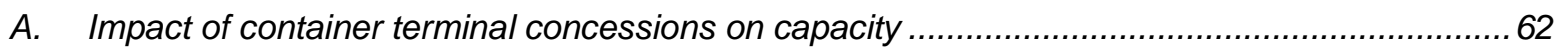

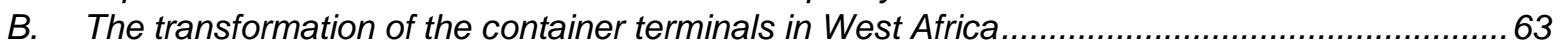

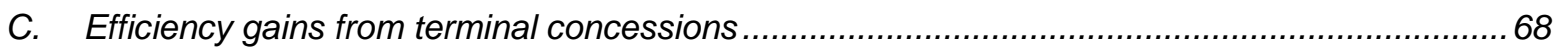

D. Impact of Concessions on container terminal prices and costs ........................................ 70

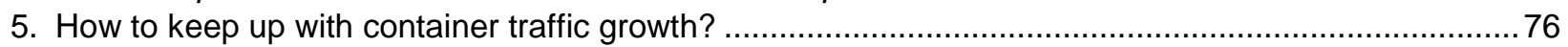

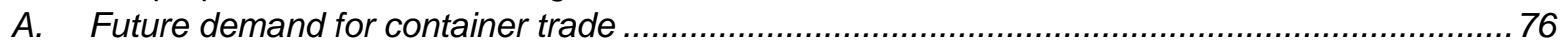

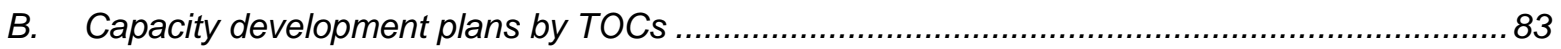

C. Long term adequacy between planned capacity and forecast demand ................................. 86

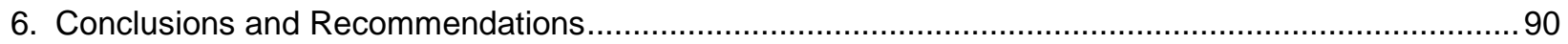

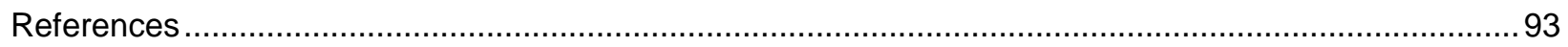

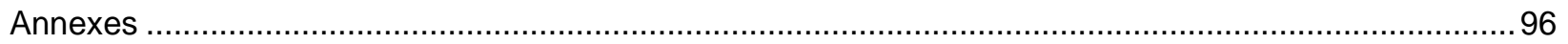

Annex 1: Main ports and container terminals in West Africa ..................................................... 96

Annex 2: How to measure efficiency gains from terminal concessions? ...................................... 102

Annex 3: The growing role of Asia in West African maritime trade .............................................. 108

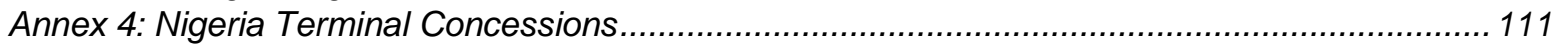

Annex 5: Characteristics of the main West African container terminals ..................................... 113

Annex 6: Tables for container traffic forecast ....................................................................... 115

\section{Tables:}

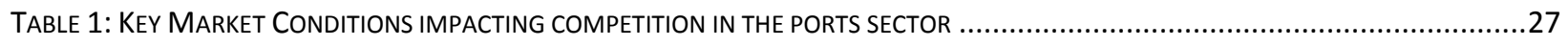

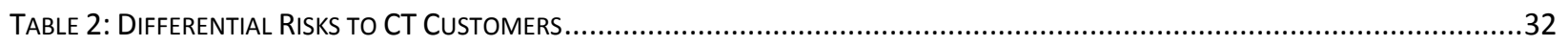

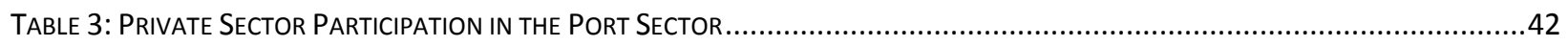

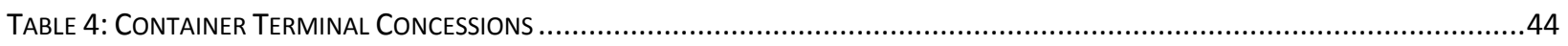

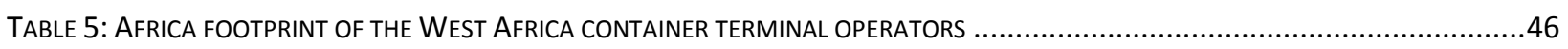

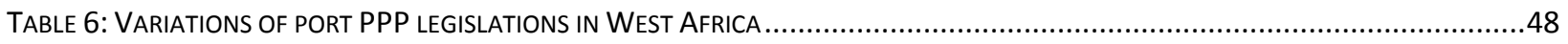

TABLE 7: NATIONAL MINISTRIES AND AGENCIES IN CHARGE OF PORT REGULATION IN WEST AFRICA ..........................................49

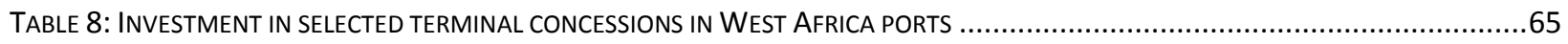

TABLE 9: REGIONAL AVERAGE FOR SHIP PRODUCTIVITY ACCORDING TO VESSEL SIZE ..............................................................6

TABLE 10: COMPARISON 2010 - 2015 OF THE CONTAINER HANDLING TARIFFS IN COTONOU ..................................................71 


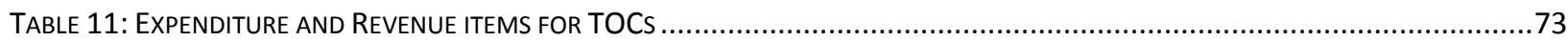

TABle 12: TeNTATIVE ESTIMATE OF THE REVENUE FOR AbIDJAN TERMINAL FOR THE YEAR 2013 (USD) ......................................74

TABLE 13: ESTIMATED CONCESSION FEE (VARIABLE) FOR ABIDJAN TERMINAL ...................................................................

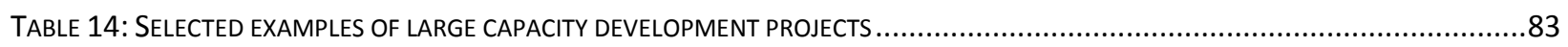

TABLE 15: PORT CAPACITY IN WEST AFRICAN PORTS BASED ON ANNOUNCED DEVELOPMENT PLANS ...............................................87

TABLE 16: CONCESSION SIGNATURE AND TAKEOVER OF OPERATIONS FOR CONTAINER TERMINALS IN WEST AFRICA .........................104

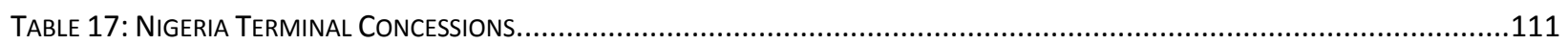

TABLE 18: CHARACTERISTICS OF THE MAIN WEST AFRICAN CONTAINER TERMINALS ..........................................................113

TABLE 19: EVOLUTION OF TRAFFIC AT THE MAIN WEST AFRICAN PORTS $(1996-2006-2011)$ IN 000S TEUs............................115

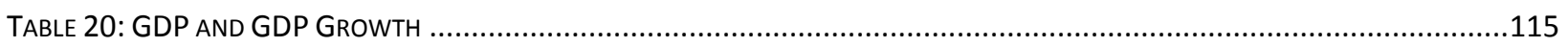

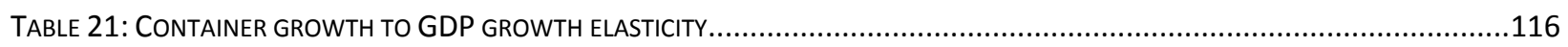

\section{Figures:}

FIGURE 1: TOTAL AND CONTAINERIZED TRAFFIC AT WEST AFRICAN PORTS (2012) ...........................................................20

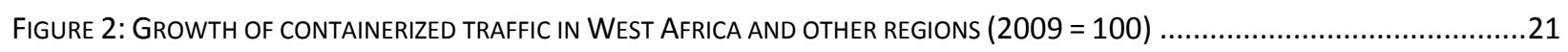

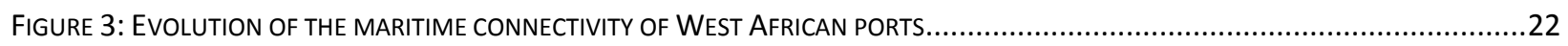

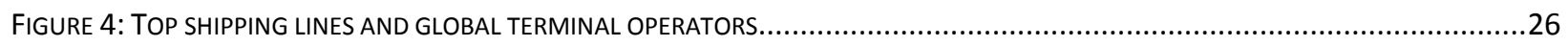

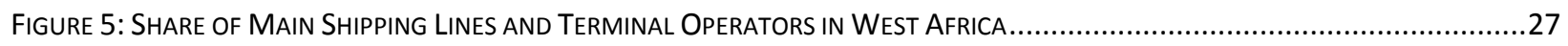

FIGURE 6: COST OF BORDER COMPLIANCE, DOING BUSINESS 2016 INDICATORS, WORLD BANK ….............................................30

FigURE 7: COST OF BORDER COMPLIANCE FOR COASTAL WEST AFRICA, DOING BUSINESS INDICATORS 2016, WoRLD BANK .................31

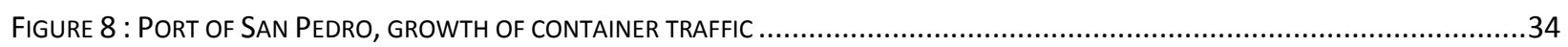

FIGURE 9: EVOLUTION OF THE MARKET SHARE OF TOCS IN WEST AFRICA (2004-2013) .......................................................45

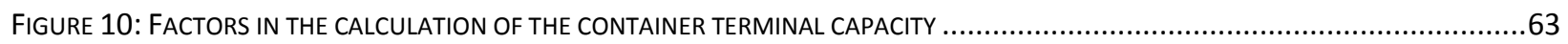

FIGURE 11: SHIP PRODUCTIVITY IN ABIDJAN AND TEMA (SOURCE: BAL) ….................................................................64

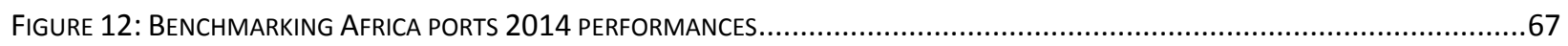

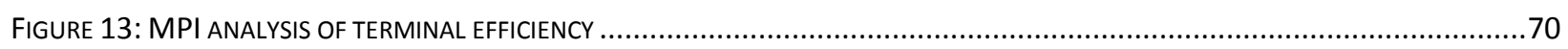

FIGURE 14: EVOLUTION OF STEVEDORING (SHIP HANDLING ONLY) RATES IN TEMA..........................................................

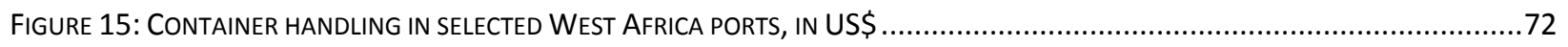

FIGURE 16: RATIO FOR CONTAINER HANDLING CONCESSIONAL RATES IN SELECTED WEST AFRICA PORTS ......................................73

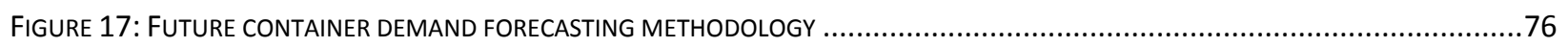

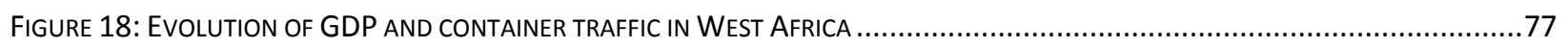

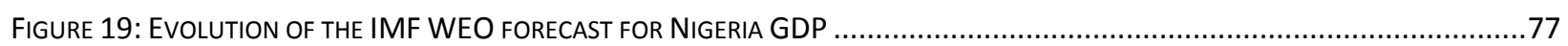

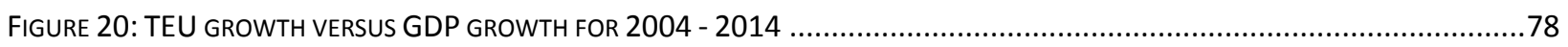

FIGURE 21: RELATION BETWEEN GDP AND CONTAINER TRAFFIC IN WEST AFRICA ...........................................................79

FIGURE 22: ACTUAL AND FORECAST TRADE RELATED CONTAINER TRAFFIC FOR COASTAL COUNTRIES (EXCLUDING TRANSIT) (MILLION TEUS),

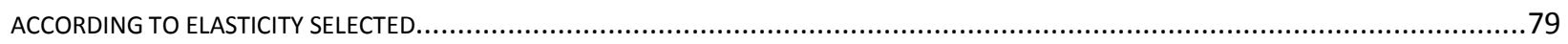

FIGURE 23: EVOLUTION OF THE ROUTING OF THE BURKINA FASO MARITIME TRANSIT TRADE ….................................................8

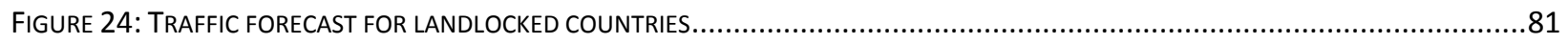

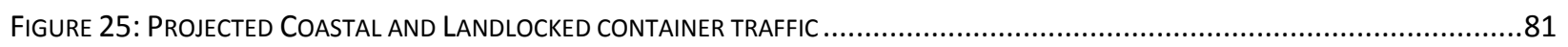

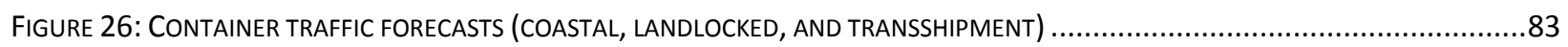

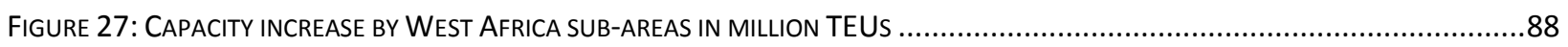

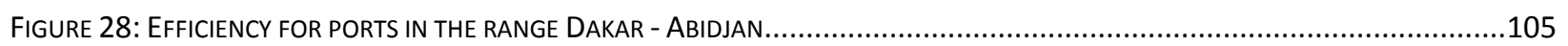

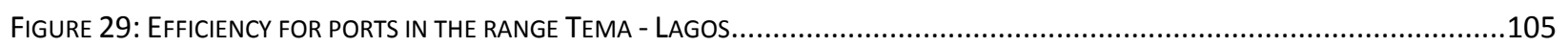

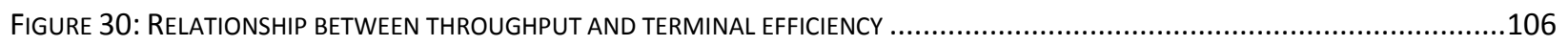

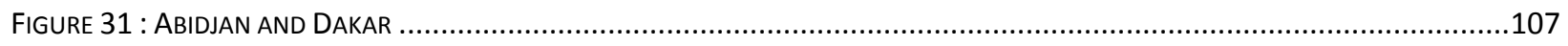

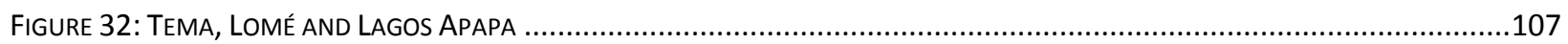


FIGURE 33: CONAKRY AND COTONOU

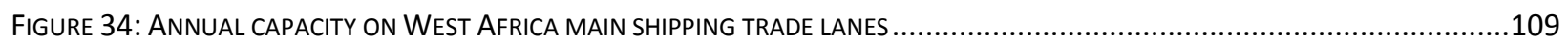

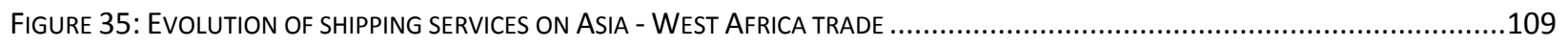

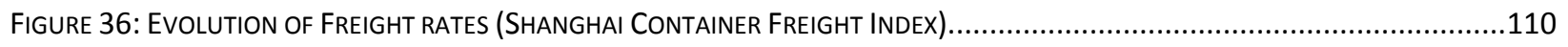

\section{Boxes:}

BOX 1: A QUESTION OF VOCABULARY - TRANSSHIPMENT HUBS, LOGISTICS HUBS AND MARITIME GATEWAYS ...............................23

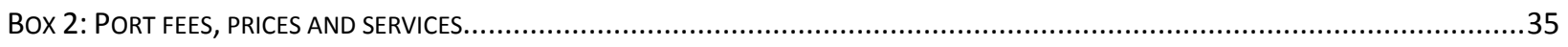

BOX 3: THE CONCESSION CONTRACT FOR THE ABIDJAN SECOND CONTAINER TERMINAL ......................................................60

Box 4: Benchmarking Container Terminal ANd Port Productivity .................................................................6

\section{Maps:}

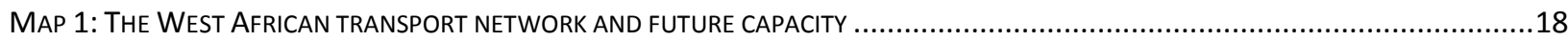

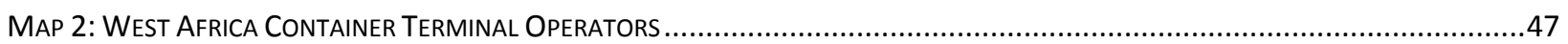




\section{Executive Summary}

\section{A - Objective of the Study}

1. This report is an assessment of the current private sector engagement (concessions) in container terminals and West Africa ports market, followed by the key lessons learned from this experience and recommendations for the way forward. As is observed worldwide, ports constitute key critical nodes of logistic chains in West Africa where overall logistics cost are among the highest in the world; ports and road transport services being the main contributors in terms of time and cost components. While inland logistics is critical in the performance of the whole transportation chain, the present report focuses on the port side of the chain. Ports' positive impact on economic growth is generally significant and mostly relies on high value-added and employment level generated by the ports activities. While ports generally have a positive impact on economic growth, they also generate negative externalities such as greenhouse gas emissions, pollution and traffic congestion. The Report offers recommendations on how to address identified weaknesses of ongoing concession contracts and improve the outcomes of the next "second generation" wave of container terminal concessions.

\section{B - Key Findings}

2. The West African port landscape has evolved rapidly since the turn of the century despite a slow start in adjusting to the requirements of modern liner shipping and containerized trade. Ports have always played an essential role in this highly trade-dependent region and have long suffered from decrepit infrastructure and poorly performing public management. While there are still wide disparities in terms of throughput volumes and capacity, port traffic has been growing rapidly in most countries over the last decade. Overall, total throughput in West Africa has grown from around 105 million tons in 2006 to 165 million tons in 2012. Likewise, containerized traffic remains comparatively limited in West Africa but has grown faster than in any other region in the world over the last five years. The combined throughput of container terminals in the region reached almost 5 million twenty-foot equivalent units (TEUs) in 2013, twice as much as a decade ago. The latest macroeconomic forecast for the region from both the World Bank and the IMF (World Economic Outlook dataset October 2016), especially for Nigeria which is highly dependent of oil and gas international market prices, shows a break in this growth path, with a contraction of the ECOWAS countries GDP of $11.9 \%$ in 2015, and a return to growth for the period 2017-2020, but at a weaker rate of $6.3 \%$ (comparing to $13.2 \%$ for the period 2006-2011). Container traffic, which follows closely GDP growth, is therefore expected to resume its growth after a small contraction in 2015 , but at an equally reduced rate.

3. The spread of container terminal concessions over the last decade has arguably been a major transformative change for West African ports. By the early 2000s, containerization of the West Africa trade was well advanced on the shipping side but ports, mostly public, were unable to keep up with investments needed to accompany the advances in containerization. It reached a point where the discrepancy between ship and port operations became a binding constraint to 
trade competitiveness and growth. Despite comparatively low container traffic, ports could not cope because of low handling productivity caused by inadequate facilities, and most ports were heavily congested prompting shipping lines to levy penalties in the form of congestion surcharges. In the absence of sufficient public resources to invest in container terminal upgrades and improve productivity, concessions to specialized Terminal Operating Companies (TOCs) were seen as "silver bullets" to modernize West African ports, notably through better equipment and management. This followed a global trend started in the 1990s towards increased private sector participation in port operations and investment, and the transition from the public service port to a landlord port model. Between 2003 and 2010, concessions transferring mostly container terminals operations were signed for all major West African ports. This has been followed in recent years by a new wave of concessions for large green field port projects in several countries in the region.

4. Concessions have brought about major positive changes. The West African port landscape has changed substantially since the first concessions came into effect in 2003, and modern container terminals now exist in most West African ports. TOCs have invested in modern handling equipment and revamped facilities. As of 2015, the concessions of the ports of Freetown, Monrovia, Cotonou, Lagos and Abidjan had resulted in respectively \$37 million, \$85 million, \$150 million, \$220 million, and \$176 million of effective additional investments. These investments resulted in productivity gains and reducing congestion: In Lagos Apapa terminal, productivity has increased from 6 moves per hour prior to the concession to 24 moves per hours at the end of 2012, reducing congestion and pre-berthing delays. In Conakry, productivity increased from 19 container movements per hour in 2011 to 35 in 2014 . Concessions have also provided Governments with millions of dollars in revenue through entry tickets, annual fees and royalty payments on traffic handled by concessionaires. Greenfield projects, which are now being contracted, are expected to further increase capacity at the regional level to meet future demand, albeit the recent slowdown in container traffic growth has led to some of these projects to be put on hold and/or facing headwinds in raising private financing, e.g., Lekki port in Nigeria.

5. Concessions, similar to public ports in Kenya and South Africa, have also allowed for opening up and adjusting to the requirements of modern liner shipping and containerized trade. With the use of increasingly larger vessels (from 1,500-3,000 TEUs in the early 2000's to 4,000-5,000 TEUs container vessels today), West Africa liner trades are less a niche market than they used to be, with new services from major shipping lines on the Asia - West Africa trade route.

6. At the same time, positive impacts of port concessions are diluted by a combination of factors. Former public monopolies at the national level have to a large extent been replaced by a region-wide, dominant position of two TOCs, which compete or cooperate in different ports and together control around 80 percent of West African container throughput. While new international TOCs are starting to enter the West African Coast market, e.g., Dubai Port World in Dakar (2007) and Terminal Investment Limited (the TIL Group) in Lomé (2011), the current market structure raises fundamental questions in terms of intra- and inter-port competition and market power, especially given the weak governance framework and regulatory capacity observed across the region. Productivity gains realized by the TOCs could likely be further improved when 
compared with the results achieved by concessionaires in, for example, Latin American countries. The latter concessions have also been accompanied by contractually agreed tariff reductions, which ensure that benefits from private participation are shared with end users of port services. Unfortunately, no such benefit sharing regime is currently implemented in West Africa's concessions.

7. The natural monopoly features of the port industry are exacerbated by the market conditions prevailing in West Africa. Ports are "naturally" monopolistic industries where large sunk investments in infrastructure facilities or unique locational advantages constitute a barrier to the entry of competitors. The thin markets of the individual countries in this region further challenge profitable operation by more than one firm in the provision of container terminal services. The monopoly position of service providers, whether public or private, can lead to a variety of economic performance issues such as excessive prices, production inefficiencies, and poor service quality. Creating competition for the market (of container terminals), via a fair and open competitive process, could address the need for regulation and government intervention. While a significant number of governments have awarded concessions on a competitive basis, the selection criteria retained to select TOC, i.e., maximization of entry and concession fees, has considerably weakened the outcome on port competitiveness. The continuance of the preexisting cargo handling high tariffs practice observed in several ports -- prior to the advent of the concession processes -- cause further doubts on the capacity of competitive tendering process to secure positive outcomes which can benefit even more the end-users of the ports.

8. Competition alone cannot be relied on for effective regulation of container terminal services, although the two types of port users - shipping lines and shippers - are not exposed to risks to the same degree. Without effective public policies and regulation, port authorities and terminal operating companies (TOCS) may not have adequate incentives to provide high quality of service, adequate facilities, or guarantee the lowest possible price that would still make private sector investment possible. While global terminal operators and major shipping lines have more or less equal market power, leading to negotiated outcomes (when TOCs are not part of the same group as the shipping lines they serve), shippers have far less service options and far less bargaining power. It is therefore the role of governments to safeguard shippers' interests (prevent monopoly rent extraction), providing them with competitive port services.

9. The experience to date suggests that West Africa countries could have further optimized their port concessions deals. For brownfield terminals, about two thirds of concessions have been attributed on a competitive rather than negotiated basis, however often to the advantage of operators who were already present as licensed stevedores prior to the concessions. Likewise, recent greenfield projects were for the most part negotiated directly with the TOCs that originated the projects, e.g., Badagry in Nigeria. Concerns about the transparency of the process and legitimacy of the outcome have been raised for a number of ports, sometimes in court. Bids have tended to be assessed, explicitly or implicitly, on the basis of their promise to maximize the direct financial benefits for Governments, rather than the economic benefits for the countries. Nevertheless, it is worth reminding that at the time of the first wave of brownfield concessions, West African countries were still categorized as niche market, with the end result of limiting the number of interested private parties in the process to the operators already 
familiar with the prevailing operating conditions. This has somewhat changed nowadays where new private operators have shown interest in this market.

10. The unfinished transformation of the ports sector can be traced to the West African institutional and governance framework as well as the economic characteristics of the CT industry. There is a double asymmetry between: (i) the countries of West Africa which lack deep experience, tools and frameworks for managing and regulating private sector firms and international TOCs, and (ii) atomistic shippers and TOCs in an industry which tends to be naturally monopolistic. The weak governance frameworks and inadequate regulation exacerbate the concentration of market power and help explain - to a certain extent -- the situation prevailing in West Africa. Notwithstanding the above, promising progress has been observed in the capacity of countries to get better deals from their port concession and on the transparency of the process. An interesting example is the evolution in the concessions for Abidjan TC1 and TC2, with the latter concession agreement made publicly available in the Cote d'Ivoire Official Gazette.

11. Despite clear benefits, the transformation of the West African ports has still some way to go. Operators have realized the bulk of the benefits essentially through technical modifications while governments have skirted the structural reforms necessary for deeper and longer lasting change. As a result, the negotiated concessions have resulted in mixed outcomes in terms of prices and quality of services. Regarding productivity, the available data suggests that the undeniable gains realized under concessions were primarily linked to the investments in modern container handling equipment and to increasing returns to scale rather than improvements in operational efficiency. In general, productivity has not improved as much as could have been expected. Given the high capital intensity and level of fixed costs in the terminal operating business, efficiency gains and continuously growing traffic volumes would have been expected to create margins for tariff reductions. However, prices for end users have not gone down and have increased significantly in some cases, generating substantial profits for TOCs. In the absence of strong competition in and for the market, regulatory and oversight mechanisms that could trigger an increased sharing of profits through automatic tariff adjustment triggers have been insufficiently developed to mitigate this risk to date.

12. In spite of the recent dampening of economic growth in the region, projected growth of container throughput in West Africa indicates that activity at port terminals could reach almost 6.2 million TEUs in 2020 and 9.0 million TEUs in 2025, or a little more than two times its 2011 level (in the worst case scenario). In the base scenario, West Africa container traffic could reach 7.5 million TEUs by 2020 and 11.2 million TEUs by 2025; in the optimistic scenario, the corresponding figures could reach 11.2 million TEUs in 2020 and 18.6 million TEUs in 2025. Even though lower than during the past decade, such growth in container trade is expected to strain existing capacities and though productivity is low by international standards, capacity reserves that could be unlocked by improved performances would be insufficient to accommodate growth of this magnitude. Meeting the challenge of this future demand will not only require expanding terminal capacity in existing ports but also building new ports, thus justifying the pipeline of port projects already announced by port authorities and terminal operating companies. 
13. The major capacity development projects will require complementary investment in the nautical infrastructure, which is traditionally the responsibility of the public sector. Even for ports which have sufficient land and marine reserves to accommodate new terminals, such as Abidjan or Lomé, the development of new terminals will require extension of the protection infrastructure facing the sea, deepening of the access channel, and extension of the turning basin. For the ports developed in greenfield sites, such as Lekki and Badagry, a completely new nautical infrastructure needs to be created. Although West Africa, following the trend everywhere else in the world, has given TOCs a greater role in the management and financing of the container terminals, the provision of nautical infrastructure remains the responsibility of national or regional public entities. Consequently, in addition to terminal operator investments, a significant amount of public investment, either funded by the port authority or the national or local governments, will be required for the concomitant upgrade or creation of the nautical infrastructure

\section{C - Way Forward and Recommendations}

14. Three categories of recommendations are proposed, with a particular focus on: (a) increasing the efficiency of port operations; (b) improving the regulatory environment; and (c) optimizing port development with a regional perspective.

\section{A - Increasing the efficiency of port operations}

15. Improved Concessions Performance Indicators Monitoring. Currently productivity measures included in contract documents are ad hoc and ill-defined and can often be misleading in their ranking of ports. Explicit and standardized measures of efficiency such as productivity (output versus time) and cost effectiveness (output versus cost) are recommended. Collecting and publicizing data on these indicators over a period of time will permit benchmarking the relative and absolute performance of each concessionaire and further competition.

Recommendation 01: Include both productivity and cost-effectiveness performance indicators in concession agreements, together with adequate incentives, based on best practices in the industry.

16. Transparency and Regional Comparisons. Generalizing the publication of tariffs and key performance indicators is the first step to improve transparency and facilitate policymaking. It would then be possible to formalize customer feedback loops by including specific provisions to this effect in concession agreements, complemented by mandatory disclosure provisions. The data collected through these systematic feedback processes at the local port level could then form the basis for a region-wide database that would allow meaningful comparisons between facilities and also hopefully nurture some emulation between them.

Recommendation 02: Include a disclosure clause in the concession agreements so that tariffs and key performance indicators are periodically published. 


\section{B - Improving the regulatory environment}

17. Policies, which harmonize regulatory oversight of monopolistic activities with fostering competition, will do much to improve the economic outcome of private sector involvement in the port sector. In other parts of the world, the potential market power of TOCs is checked through a combination of inter and intra- port competition as well as independent regulatory/oversight entities. Ex-post, inter-port competition in West Africa is currently hindered by barriers to inland transport and cross-country movement of traffic and goods which impact the availability of contestable hinterlands, while ex-ante, intra-port competition is possible only in a few ports where traffic is high enough to sustain more than one terminal operator.

18. These limitations may be overcome if there is, for example, sufficient competition for the market (by auctioning the right to operate a port or operate within a port) that allows reduction or elimination of monopoly rents through a fair, transparent and public tendering process. Equally, depending on the criteria for the award of the concession, the conceding authority could attempt to seek a reduction in tariffs rather than maximizing revenues, again improving the outcome. Competition for the market occurs at discrete points in time while performance improvements can also be built into, and enforced via, contract documents and management through the life of the concession. To obtain these results, the focus has to be on: (i) improving the concession process; (ii) getting the competition framework right; and (iii) strengthening the concession contract documents. In addition, competitive outcomes can be achieved through an assessment of the relative and absolute operational and financial performance of each port, that is, (iv) yardstick competition.

Recommendation 03: Award port concessions through a fair, transparent and public tendering process, seeking a reduction in tariffs rather than maximizing Government's revenues.

19. Regulation/Oversight of concession agreements. It is important for countries to resolve who is responsible for regulating the concessions. There are alternative options to dedicated competition authorities: at regional and national level several existing institutions have some form of mandate in transport and corridor performance (PMAWCA corridor institutions, industry associations, facilitation committees etc.). Countries and RECs, which established them, could expand their mandate to include port terminal concession oversight and tariff regulation.

Recommendation 04: Clarify the institutional framework for port concession regulation. This could be done for example through a clearer definition of the responsibilities of the Ministry of Transport in its role of Technical Regulator and those of the Ministry of Economy/Trade in terms of Economic Regulator as currently done in Senegal.

20. Strengthening the concession contract documents for future concession, while improving what can be improved in the current ones. When appropriate, either as part of their renewal process, or resulting from a renegotiation clause (if and when it exists), the revision of concession agreements may be advisable to reduce port tariffs, improve competitiveness, and 
allow meaningful monitoring of performance. Such changes should aim at improving the distribution of benefits amongst stakeholders: reduction in tariffs could reduce government revenues but would benefit shippers and generate positive spill -over effects into the local economy. Since there is an inherent asymmetry of power and negotiating capacity between the ultimate clients of the ports and the TOCs, systematically disclosing operational and cost information to the general public provides an opportunity to bring together the virtual constituency of regional port users. A good example is the publication of the concession agreement for the Abidjan TC2 by the Ivorian authorities. This should be done carefully, however, as badly renegotiated contracts might send negative signals in the market to future private investors sought after to develop competitive TOCs.

Recommendation 05: Whenever appropriate, revisit the distribution of benefits from port activities amongst stakeholders through adjusted tariffs with a view to increase returns for end users and the general economy.

\section{C-Optimizing port development with a regional perspective}

21. Redesign of future concession award processes. With the expected continued growth of port traffic and the forthcoming renewal of existing concessions, it is critical to revisit now the concession award process to better manage the next "second generation" wave of concessions. Adequate resources need to be set aside for the public sector to access the necessary expertise to strengthen further public capacity to design and to negotiate concession agreements, to conduct transparent bidding processes which allow fair competition for the market and offer equal opportunities to new entrants, and to recalibrate the criteria for contract award towards economic impact as opposed to financial returns. In exceptional circumstances a negotiated process could be warranted, notably when TOCs and shipping lines join forces to promote a transhipment terminal.

Recommendation 06: PMAWCA to issue relevant recommendations for the redesign of future concession award processes, using the guidelines currently produced under the World Bank SSATP initiative.

22. Regional perspective. In order to avoid costly port overcapacity, their future development should be essentially driven by the market, which - most likely -- implies a few regional port hubs servicing the other smaller ports through short sea shipping services. Both ECOWAS and PMAWCA are interested to provide guidance to their country members with a view to optimize the port network along the West Africa Coast. Actually, two studies have just been commissioned by the ECOWAS for that purpose: (i) The socioeconomic of port concessions study (CPCS Consult of Canada to start in July/August 2017); and (ii) the Development of a maritime and port infrastructure master plan for West Africa (MTBS Consultants, started in May 2017).

Recommendation 07: Both ECOWAS and PMAWCA to continue to provide guidance to their country members with a view to optimize the port network along the West Africa Coast. 
23. Notional Timeframe. Due to their very nature, these seven recommendations cannot be implemented within a single time frame. The table below proposes a notional timeframe for implementing each of the seven recommendations under short, medium and long-term horizons.

\begin{tabular}{|l|c|c|c|}
\hline \multicolumn{1}{|c|}{ Recommendation \# } & Short-Term & Medium-Term & Long Term \\
\hline 1. Define Key Performance Indicators (KPI) & - & & \\
\hline 2. KPI and tariffs periodically disclosed & & $\square$ & \\
\hline 3. Code of conduct for future concessions & & $\square$ & \\
\hline 4. Clarified port concessions regulation & & & $\square$ \\
\hline 5. Tariff Strategy in concession agreements & & $\square$ & \\
\hline 6. Redesign of future concession processes & $\square$ & & \\
\hline 7. Regional Port Master Plan & & & $\square$ \\
\hline
\end{tabular}




\section{The West African Ports Landscape and Containerized Trade}

\section{A. Geographic, demographic and economic overview}

1. West Africa is a relatively large region with a majority of coastal countries ${ }^{1}$. The combined land area of ECOWAS countries is just over 5 million $\mathrm{km}^{2}$, which represents 21 percent of the Sub-Saharan African (SSA) landmass and is a fifth larger than the European Union. While Niger and Mali are over 1.2 million $\mathrm{km}^{2}$ each, six countries are under 100 thousand $\mathrm{km}^{2}$. Of the 15 ECOWAS countries, 11 have a coastline, 3 are landlocked, and one is an island country. The average size of coastal countries is 189 thousand $\mathrm{km}^{2}$ (124 thousand excluding Nigeria). The West African coastline totals just over $4,300 \mathrm{~km}$, with national coastlines ranging from around $850 \mathrm{~km}$ in Nigeria to $56 \mathrm{~km}$ in Togo.

2. The West African population is highly concentrated and will boom in the next decades. The combined population in the region is around 350 million inhabitants (37 percent of SSA and 5 percent of the world). Nigeria accounts for half of this number, but 12 countries in the region have less than 20 million inhabitants. Population density varies greatly, from 191 people per km² in Nigeria to 13 in Mali. West Africa's population is highly concentrated along the coast, although there are also some large cities in the hinterland. Population growth has averaged 2.6 percent per annum since the beginning of this century, in line with the SSA average. Looking forward, the United Nations estimates that West Africa will become the most populous region on the continent, reaching over 800 million people by 2050 and 1.6 billion by 2100 (respectively 9 and 15 percent of the world's total population by then) ${ }^{2}$.

3. The economies of West African countries have been growing rapidly albeit with a slowdown in recent years reflecting the global decline in commodities and oil prices. The combined GDP of ECOWAS countries amounted to US\$720 billion in 2014, less than 1 percent of the world's GDP (42 percent of SSA's GDP). Nigeria accounts for over three quarters of this figure, while nine countries of the sub-region have a GDP of less than US\$10 billion. As per the $\mathrm{IMF}^{3}$, Gross Domestic product (GDP) for West Africa contracted by $11.9 \%$ in 2015 , and by a further $10.3 \%$ in 2016, but is expected to rebound in 2017. Economic activity is expected to resume its growth at an average annual rate of 5.3\% for the period 2016-2021. The realization of the growth prospects for West Africa will continue to be influenced by improvements in its institutions and implementation of policies necessary to sustain growth and promote economic diversification, in addition to global factors.

\footnotetext{
${ }^{1}$ Unless stated otherwise, "West Africa" refers in this report to the region made up of the 15 member countries of the Economic Community of West African States (ECOWAS), namely Benin, Burkina Faso, Cabo Verde, Cote d'Ivoire, the Gambia, Ghana, Guinea, Guinea Bissau, Liberia, Mali, Niger, Nigeria, Senegal, Sierra Leone, and Togo. 2 United Nations, World Population Prospects, 2012 Revision.

${ }^{3}$ IMF World Economic Outlook dataset for October 2016
} 
4. The economic structure of West Africa has not seen much change in recent years and the region remains highly dependent on trade with the rest of the world. Economic activity in the region is highly concentrated: economic density exceeds US\$1 billion per hundred $\mathrm{km}^{2}$ in large urban centers along the coast, but decreases rapidly as one moves inland to below US\$10 million in the Sahel region (Ranganathan and Foster 2011). The economic structures of ECOWAS countries are dominated by the agricultural and services sectors, while the share of manufacturing in GDP has remained below 10 percent on average. West Africa has traditionally exported unprocessed agricultural products, as well as increasing volumes of petroleum and mining products, while importing manufactures produced in other continents. Trade with partners outside the region, which occurs almost exclusively via maritime transport, represented on average 91 percent of ECOWAS countries' imports and 94 percent of their exports between 2010 and 2013. Over the same period, extra-regional trade amounted to around 40 percent of the countries' aggregate GDP. While Europe remains West Africa's first trade partner in value, its share in total trade has steadily declined over the recent decade, while the share of Asian countries has increased.

\section{B. The development of the West African port sector}

5. Ports play a critical role in trade and economic activity in ECOWAS countries. Ports in West Africa, many of which were established during the colonial period, have historically constituted the most developed part of transport networks. The dependence on maritime transport for international trade has ensured the ports a captive clientele and continued traffic despite operational struggles ${ }^{4}$. Most ECOWAS countries are small economies in which port operations represent a vital part. With no land access to distant consumer markets and little production of high value added goods that could justify air transport, ports have a central role to play as the gateway linking West African economies to the rest of the world. And with globalization of the world's economy, the competitiveness of a country's exports of raw materials, intermediate inputs and final goods is increasingly connected to the efficiency and costs of its shipping services.

6. Externalities. Ports' positive impact on economic growth is significant and mostly relies on high value-added and employment level generated by the ports activities. Such features are likely to be prone to high transport density network and innovation, but also to negative externalities such as $\mathrm{CO} 2$ pollution and traffic congestion. While clearly outside the scope of the present study, the three following negative externalities deserve the attention of the governments: (i) climate change and coastal erosion; (ii) sea pollution and loss of biodiversity; and (iii) national security face with piracy and terrorist activities.

\footnotetext{
${ }^{4}$ In comparison, poor infrastructure and services on West African railways have exposed them to intense competition from road transport.
} 
7. West African ports are central nodes of regional trade and transport networks. The regional transport system is made up of two West-East corridors (Dakar-Niamey and AbidjanLagos) and half a dozen North-South axes (e.g. Abidjan-Bamako/Ouagadougou, CotonouNiamey), which link ports with markets mostly centered around capital cities). The landlocked countries rely heavily on transit to transport goods to and from ports in the coastal countries. In fact, one port (Cotonou) plays a more important role as a gateway for the region than for its domestic market.

8. History has shaped the development of ports in West Africa. The structure of the West African port range, and more broadly of transport infrastructure networks in the region, was shaped by colonial powers with the main objective of supporting the exploitation and export of natural resources (e.g. peanuts on the Niger/Dakar route; bananas on the Niger/Conakry route; coffee, cocoa and timber on the Niger/Abidjan route; and cotton, cocoa and mining products on the Gold Coast/Cape Coast routes) (Debrie 2012). This has led to the development of numerous small ports with basic facilities along the coast of the Gulf of Guinea, which are linked by road and railways to inland production centers, but not to each other in order to protect the monopoly of competing colonial powers on specific trade and export routes. This structure was later consolidated by the planning policies of newly independent States in the post-colonial period. In this context, port infrastructure and services, as well as railways, were owned and operated as public monopolies. 
MAP 1: THE WEST AFRICAN TRANSPORT NETWORK AND FUTURE CAPACITY
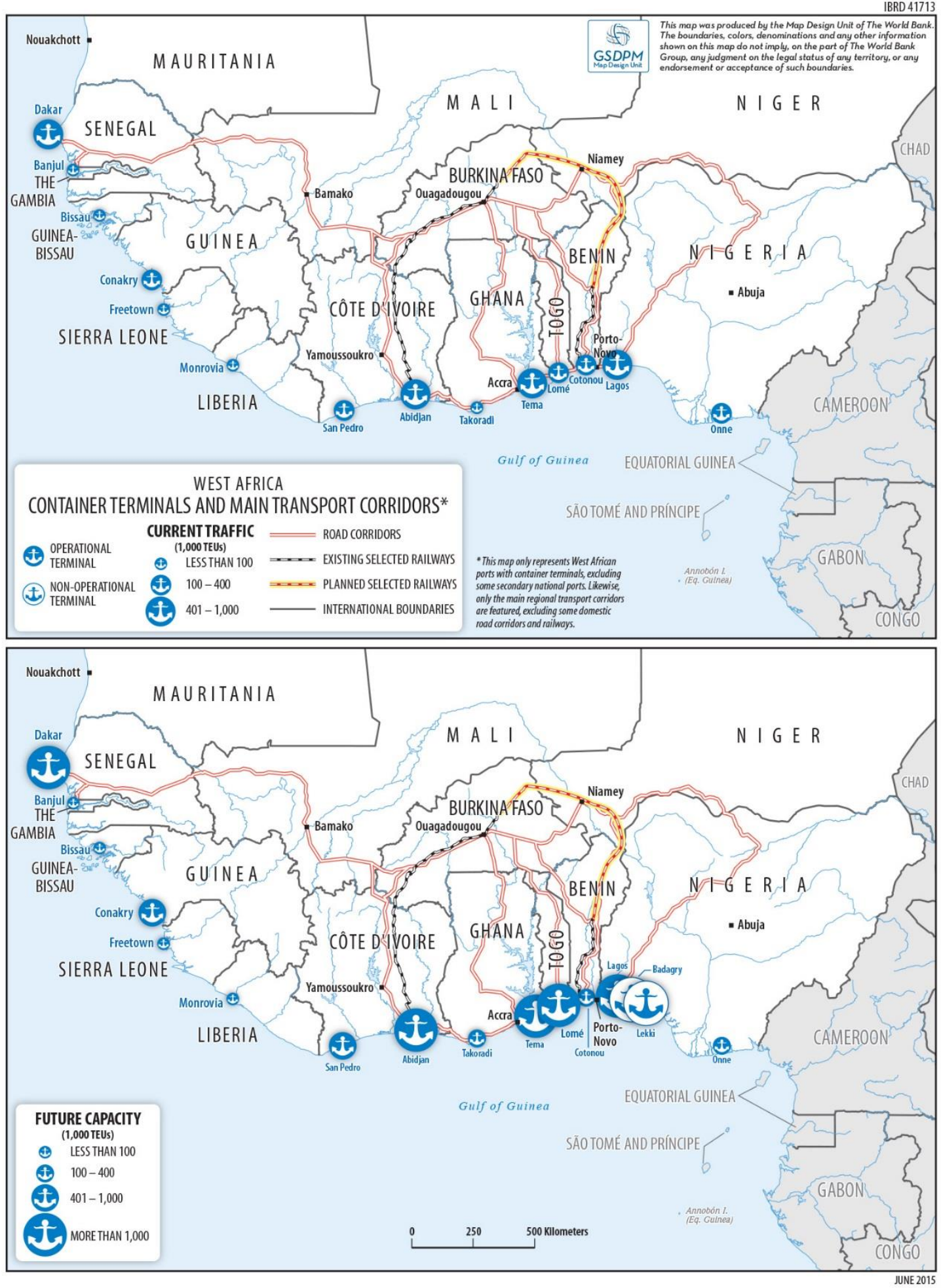
9. Following the global trend with some delay, private sector participation in port management and development gained momentum in West Africa at the turn of the millennium. As discussed in more detail in the third chapter, port authorities gradually involved specialized private companies in cargo handling through licensing, shifting from the public service port model to the tool port model. This was motivated by the need to radically transform the ports which were then characterized by low productivity, low service levels and inadequate investments due to limited public resources. Because ports were critical for integration of the region into international trade, international agencies called for institutional reforms complemented by an increased role for the private sector (UNCTAD 2003, World Bank 2001). Strong growth of world trade put additional pressure on port authorities to respond to the need for improvements in handling efficiency and to expand facilities which would accommodate larger cargo flows. As a result, by the end of 2002, eight ports in SSA, mainly in West Africa Economic and Monetary Union (WAEMU) countries, had experimented with leasing port equipment to the private sector (UNCTAD 2003).

10. Private sector participation in port services increased further during the last decade with the concession of container terminals to specialized terminal operating companies (TOCs). The preferred approach to port management became the landlord port structure, under which the public sector owns basic infrastructure assets and retains regulatory functions, but divests the managerial and financial responsibilities for commercial facilities. This institutional arrangement also allowed for different forms of public-private partnership, which have brought about major positive changes. The gradually increasing private sector involvement in the operations of port facilities in West Africa mirrored the global trend of the 1990s when 104 ports in 24 developing countries reached financial closure on concessions with investment commitments totalling over US\$8 billion (Juhel 2000). The majority of the commercial ports that handle containers and general cargo traffic in the ECOWAS region are today operating under one form of concession or another.

11. There are wide disparities in throughput volumes among ports in West Africa, but traffic has been growing significantly in all countries. There are over 25 commercial ports along the coast between Dakar and Lagos, of which around 20 handle container and general cargo traffic. The coast hosts half a dozen major ports (Dakar, Abidjan, Tema, Lomé, Cotonou, Lagos), which account for the bulk of total throughput (Figure 1$)^{5}$. In addition, a number of secondary ports in smaller countries serve mainly their domestic markets, and specialized ports are used for the export of petroleum products and mineral resources. In terms of volume, inward flows largely dominate port traffic, accounting in 2013 for 78 percent of total throughput at the port of Dakar, 65 percent in Abidjan, 82 percent in Tema and 76 percent in Lomé. Total throughput in West African ports grew from around 105 million tons in 2006 to 165 million tons in 2012 (61 to 87 million without Nigerian ports). During this period, traffic volume increased by more than 5

\footnotetext{
${ }^{5}$ See Annex 1 for a brief presentation of each of the main West African container terminals.
} 
percent per year in the ports of Dakar (5.8\%), Monrovia (9.2\%), San Pedro (21.6\%), Tema (6.1\%), Lomé (7.3\%), Cotonou (5.6\%), Apapa (5.6\%), Tin Can (12.5\%) and Onne (9.3\%).

FIGURE 1: TOtAL AND CONTAINERIZED TRAFFIC AT WEST AFRICAN PORTS (2012)

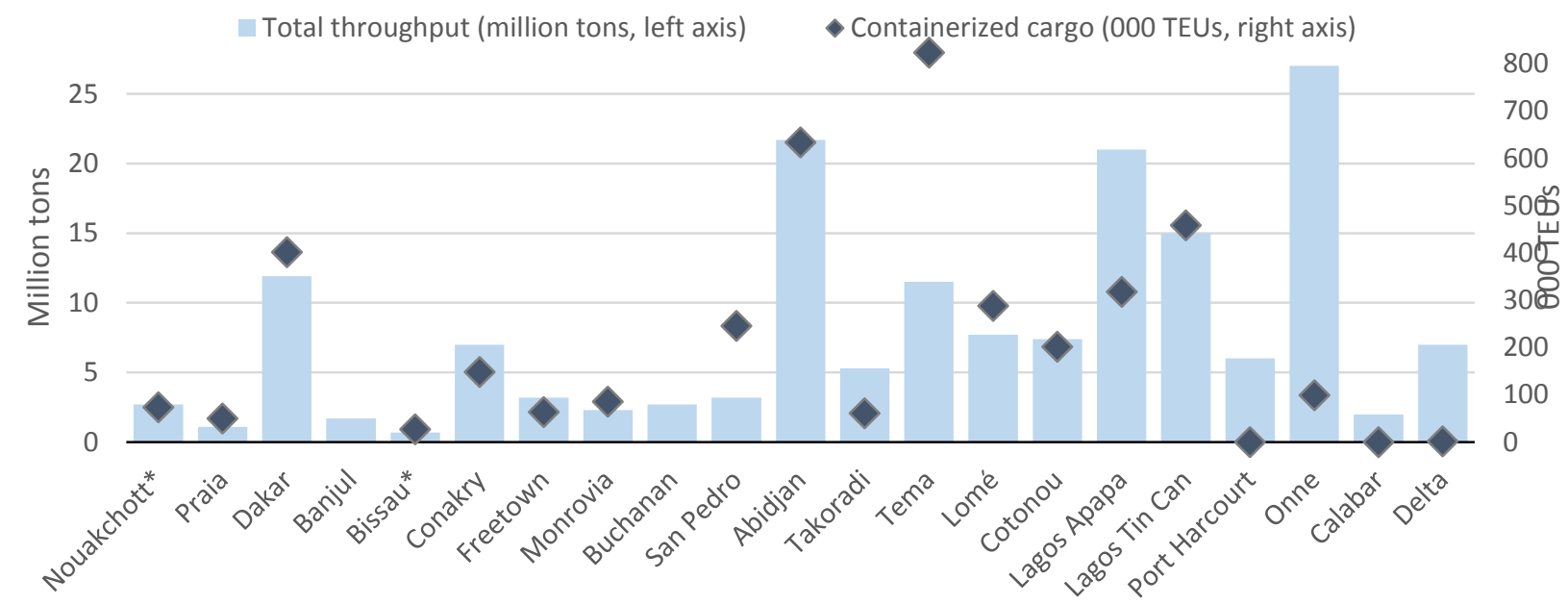

Source: Port authorities. *: 2010 data

12. West African ports differ widely in terms of physical characteristics and equipment. The size and type of vessels that can be serviced varies across ports. In container terminals, linear quay lengths ranging from 190 meters (Takoradi) to 920 meters (Lomé), and drafts ranging from 9 meters (Takoradi) to 15 meters (Lomé), mean that some ports cannot accommodate ships carrying more than 2,000 TEUs, while container vessels of up to 6,000 TEUs can call at a few others (MLTC / CATRAM 2013). Likewise, the quality of container handling equipment varies greatly among terminals, some ports having invested in post-Panamax ship-to-shore (STS) and rubber-tyred gantry (RTG) cranes, while others have no such equipment and therefore rely on geared vessels. While the smallest ports only have a general cargo quay, the larger ones have dedicated terminals (e.g. containers, liquid bulk, RORO ${ }^{6}$ ) and storage facilities (e.g. reefer outlets).

13. Compared to other regions, containerized traffic in West Africa is still limited though it has been growing rapidly. Over the last decade, containerized traffic boomed in some ports, such as San Pedro and Tema. Leading ports in terms of container throughput include (by order of importance) Lagos, Tema, Abidjan and Dakar, but several ports still handle a limited number of containers every year (Figure 1). Although starting from a low base, container volumes handled in West Africa have grown faster than in any other region in the world over the last five years (Figure 2). The combined throughput of container terminals in the region reached almost 5 million TEUs in 2013, twice as much as a decade ago. Generally speaking, West African container terminals nonetheless remain modest in size compared to the large hubs in the Northern and

${ }^{6}$ Roll-on/Roll-off, for ships designed to carry vehicles. 
Southern tips of the continent, such as Algeciras in Spain (4.5 million TEUs in 2013), Tanger Med in Morocco and Durban in South Africa (2.6 million TEUs each) (Containerization International 2014). Compared to South Africa, and to the global average, most West African countries still handle low volumes of containers relative to total port throughput and to the size of their economy and population. This suggests that there is potential for further container traffic growth in West Africa.

FigURE 2: GROWTH OF CONTAINERIZED TRAFFIC IN WEST AFRICA AND OtHER REGIONS $(2009=100)$

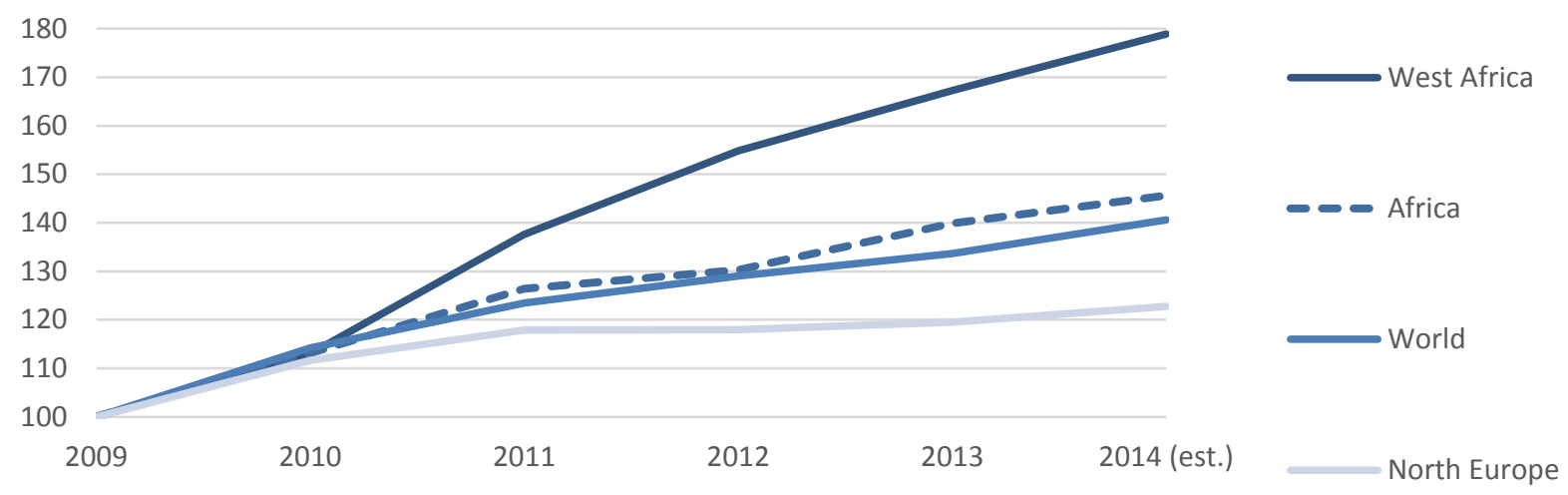

Source: Drewry, as reported in Ecorys (2015)

14. The dominance of imports over exports across West Africa is most pronounced in the container trade. The structure of merchandise trade is geared towards bulk exports and manufactured imports with minerals and agricultural products handled either by specialized or dedicated dry or liquid bulk terminals or general cargo facilities ${ }^{7}$. The value of merchandise imports is almost double that of merchandise exports such that inward traffic is generally two or three times as large as outward traffic in volume terms. For containers, this translates into a large proportion of boxes discharged full being loaded back as empty containers. The ratio of loaded export to import containers is on average $55 \%$ across the region ${ }^{8}$, with variations between $20 \%$ for Dakar and almost a balanced traffic in Abidjan.

\section{West African Integration with global shipping}

15. West Africa is connected to the global liner-shipping network by a combination of endto-end and transshipment services articulated around hub ports outside of the region. The current mix of services comprises end-to-end (ETE) services connecting the coastline directly with the major industrialized regions of Europe, North America and East Asia, and relay services connecting with main line services via hub ports around the Strait of Gibraltar, such as Algeciras and Tangier, and further away, such as Las Palmas in the north, and, to a lesser degree, via hub ports such as Durban, Cape Town and Coega to the south. Europe has historically been West

\footnotetext{
${ }^{7}$ Africa's Infrastructure: A Time for Transformation, edited by Vivien Foster, Cecilia Briceno-Garmendia

${ }^{8}$ Proportion calculated for the ports of Dakar, Abidjan, Tema, Lomé and Cotonou, for which the decomposition of the container traffic between full in and full out were available
} 
Africa's dominant trade partner, but Asia's importance increased rapidly from the second half of the 2000s (see Annex 2).

16. West Africa remains to a large extent an isolated region in the global liner network. Connectivity, as measured by UNCTAD's Liner Shipping Connectivity Index, is low for West African ports. Connectivity has not progressed at the same pace as traffic over the last decade and remains low compared to Morocco and South Africa (Figure 3), where connectivity was boosted by the development of major transshipment hubs and traffic growth. However, some direct routes have emerged between Asia and West Africa's large ports, such as Abidjan and Lagos (Alix 2011), and more recently Lomé, which are linked to smaller countries by sub-regional feeder routes. The level of transshipment within the region is limited but quickly picking up, and this situation is currently changing due to rapid trade growth that is changing the parameters of the cost equation for shipping lines.

FIGURE 3: EVOLUTION OF THE MARITIME CONNECTIVITY OF WEST AFRICAN PORTS

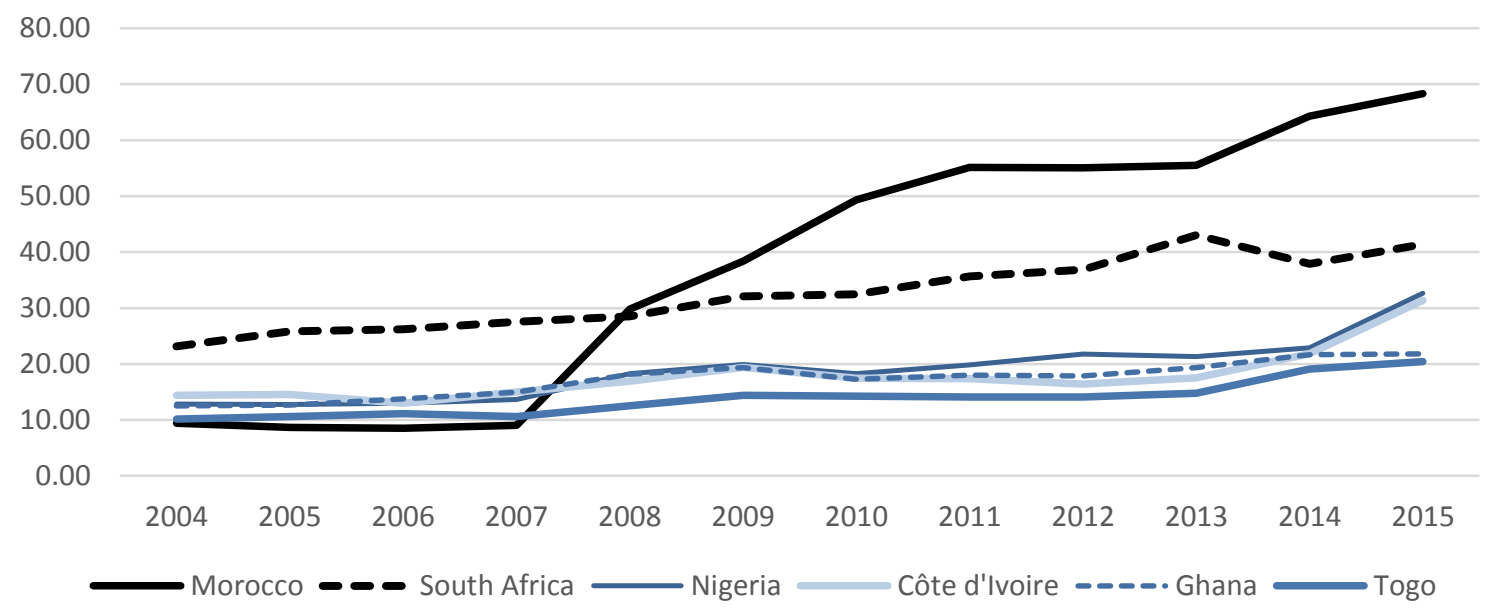

Source: UNCTAD LSCI 2016

The level of transhipment in any region depends on the global strategies of the shipping lines and the organization of their networks. Until recently, most of the transhipment in West Africa was opportunistic as services on the main trade lanes, Europe and Asia, were a combination of direct and regional services articulated from an external hub. Consequently, the share of transhipment in West African ports was below that of other regions in the world. The decline in Europe's dominance of maritime trade over the last decade, with shipping lines relying exclusively on hubs in the Mediterranean (Algeciras for Maersk, Valencia for MSC and tangier Med for CMA-CGM) has permitted consideration of alternative locations, including ports in West Africa, as hub ports. Some governments see the large volumes handled by transshipment ports and believe that converting their port into a transshipment hub will bring economic benefits in the form of high concession fees and royalty payments. But transshipment cargo may not be very good business for either a government or for a private port operator. Transshipment only makes sense for ports located in places with ideal geographical and natural conditions where the ports can succeed with a "supermarket" approach: very high volumes at a low price together with very 
high efficiency, which can generate an attractive return on investment despite low revenues per move9.

BOX 1: A QUESTION OF VOCABULARY - TRANSSHIPMENT HUBS, LOGISTICS HUBS AND MARITIME GATEWAYS

The notion of a logistics hub refers to a node in a network. When applied to ports and shipping, however, it frequently evokes the notion of transshipment, a specific function in a shipping network.

To distinguish between the two notions, a different vocabulary is being used here, consistent with the commonly accepted designation of ports in the specialized literature:

Hub (sometimes transshipment hub) refers to nodal position in a shipping network organized with main lines connecting in selected hub ports with a network of feeder or other intersecting main lines,

Maritime gateway refers to a port serving a large regional hinterland extending beyond the national boundaries

These two functions may coexist in a given port, or a port can perform either one of the functions, or neither for secondary ports. For ports within and close to West Africa, Algeciras at the Strait of Gibraltar is an example of pure transshipment hub, Cotonou an example of pure gateway, and Abidjan or Dakar examples of ports combining the two functions.

17. The idea of a hub and spoke structure along the West African coast has been gaining traction over several years and its implementation appears imminent. The increasing likelihood of one or more hubs being established in West Africa may be attributed to the increasing traffic on the Asia - West Africa trade lane, the evolving strategies of shipping lines and the "cascading effect" of new post-panamax container vessels on East-West routes. The latter evolution has pushed larger ships to North-South routes serving West Africa and created a requirement for ports with sufficient capacity and draught to handle these ships. Identification of a suitable base port in West Africa has been under consideration by both CMA-CGM and MSC, the two main shipping lines serving West Africa, for several years. In 2008, MSC reached agreement with the port of San Pedro confirming its intentions to develop the port as MSC's West Africa hub. However, with the uncertainties of the situation in Cote d'Ivoire and the limited cargo base of San Pedro, MSC continued to explore and in 2011 settled on Lomé as its choice for a hub in West Africa. CMA-CGM had also identified Lomé's potential in the past along with that of Sao Tome and Principe. These on-going quests by shipping lines have long fuelled national desires to be the "chosen" ones. CMA-CGM's hunt for a suitable hub port appears to now be over with the purchase of a stake from ICTSI (International Container Terminal Services) in the port of Lekki, Nigeria, which is likely to become the shipping line's West Africa hub when it opens. Despite the selection of Lomé as a potential hub, Maersk retains flexibility in finalising its selection given its involvement, through its subsidiary APM Terminals, in several major ports: Abidjan, Tema, Lagos Apapa, and soon, Badagry in Nigeria. Once confirmed, the sub-regional hubs are expected to handle cargo between West Africa and large transshipment platforms in North Africa, with other

${ }^{9}$ IFC Handshake Issue No. 6 (July 2012) 
sub-regional ports increasingly served by feeder lines (USAID 2005, AICD 2009, Brooks et al. 2014).

18. Coordinated development of gateway ports could help resolve the problem of an efficient port system in West Africa provided inland infrastructure and bureaucratic facilitation issues are adequately addressed. Container demand can originate from two different sources: inland, for gateway ports, and at sea, for transshipment hubs (see Box 1). Large gateway ports must draw traffic from a large hinterland, which, considering the size of the economies in West Africa, means that this hinterland must extend beyond the confines of the coastal country in which the gateway is located. Facilitating trade and transport on the landside will therefore be essential to support large gateway ports. This would require (i) changing policies, regulations and behaviors to lift obstacles to cross-border trade and investment, as well as (ii) improving land transport networks through investment in road infrastructure, development of railways along major corridors, establishment of inland logistics platforms, etc. (Alix 2015). Transshipment hubs require the long-term commitment of a shipping line to be viable. Usually, that commitment takes the form of large investments sunk into the development of the facility, and the choice of the regional hub normally defines the structure of the liner network for the entire region. 


\section{The Economics of the Port Sector and Implications for West Africa}

\section{A. Features and Economics of Natural Monopolies}

19. The presence of particular features in the demand and production of a good or service can lead to the emergence of a single supplier (monopoly) in that market. Monopolies stemming from the nature of the market rather than barriers to entry imposed by policy are referred to as natural monopolies. Monopolies can be found when there are large internal economies of scale, so that the minimum efficient scale is not reached until the firm has become very large in relation to the total size of the market, ${ }^{10}$ or when certain unique geographical features prevent the emergence of competing facilities. Particular attributes of a technology for producing certain goods and services can also be the cause of a "natural' monopoly. The presence of one or more of these features implies that a single supplier can provide a homogenous good or service more economically than two or more firms, or that one firm can produce many different products at lower cost than two or more firms (referred to as 'economies of scope'). Such natural monopolies are often seen in smaller markets as in the countries of the West Africa region, infrastructure facilities (ports and airports) with large sunk costs and/ or location advantages, and certain network industries. The market for a natural monopoly may encompass a regional market, the entire domestic market or extend beyond a single region.

20. Under certain circumstances, the port industry, or services within it, may display monopolistic tendencies leading to a variety of economic performance problems such as excessive prices, production inefficiencies, costly duplication of facilities, and poor service quality. These inefficiencies have potentially undesirable productive and distributional impacts ${ }^{11}$ with social costs. To achieve productive efficiency, it may be necessary to allow only one firm in the market, because it is the only case when the value of the inputs used to supply the market is minimized. However, the absence of competition could encourage the monopolist to set prices above marginal cost, thereby obstructing the achievement of allocative efficiency which is produced when prices are set as close as possible to production costs (Angeldonis, 2010). High port and shipping costs linked to container terminal monopolies can have a dampening impact on trade similar to general duties ${ }^{12}$. In some instances, neither productive nor allocative efficiency is achieved. It is in such cases when market mechanisms fail that government intervention and regulation of price and service levels is needed. However, regulation is not a panacea, especially in the case of developing countries where institutional frameworks are weak and regulatory decisions may be biased due to interest groups or political considerations (this is

\footnotetext{
${ }^{10}$ Economies of scale cause the long run average unit costs to decrease over most of the market making it uneconomical for other firms to enter the market.

${ }^{11}$ Regulation of Natural Monopolies, Paul L. Joskow, MIT. A. Mitchell Polinsky \& Steven Shavell (eds) Handbook of Law and Economics, 2007

12 Port Reform Toolkit, Second Edition. The World Bank, 2007.
} 
further elaborated in Chapter 3) and may lead to economic costs bigger than those generated by the market failure being corrected.

\section{B. Organization of the Port and Shipping Industry: Globally and in West Africa}

\section{Globally, the port and shipping industry is a capital intensive and highly concentrated} industry (Figure 4), where large sunk investments constitute barriers to entry that limit competition. This concentration is particularly marked for the liner shipping industry, as the top three lines collectively control $37.2 \%$ of the world container fleet, measured in TEUs ${ }^{13}$. That concentration is increasing: 20 years ago, the top five shipping lines had comparable fleets, while in 2015, the third-largest operator, CMA-CGM, operates a fleet twice the size of the fourthlargest, Evergreen Line ${ }^{14}$. The level of concentration is less marked for global TOCs: the top three, measured by equity TEU ${ }^{15}$, controlled $20 \%$ of the world container throughput, and the top five controlled almost $30 \%$.

\section{FIGURE 4: TOP SHIPPING LINES AND GLOBAL TERMINAL OPERATORS}

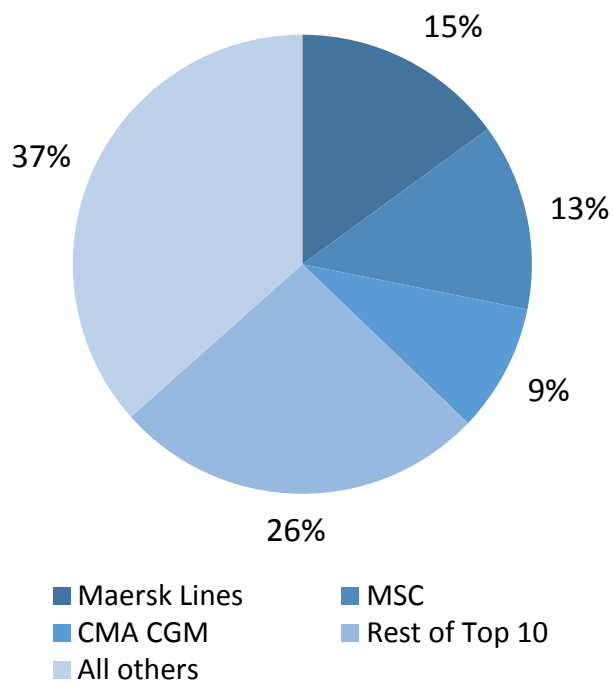

Source: Alphaliner Top 1002015

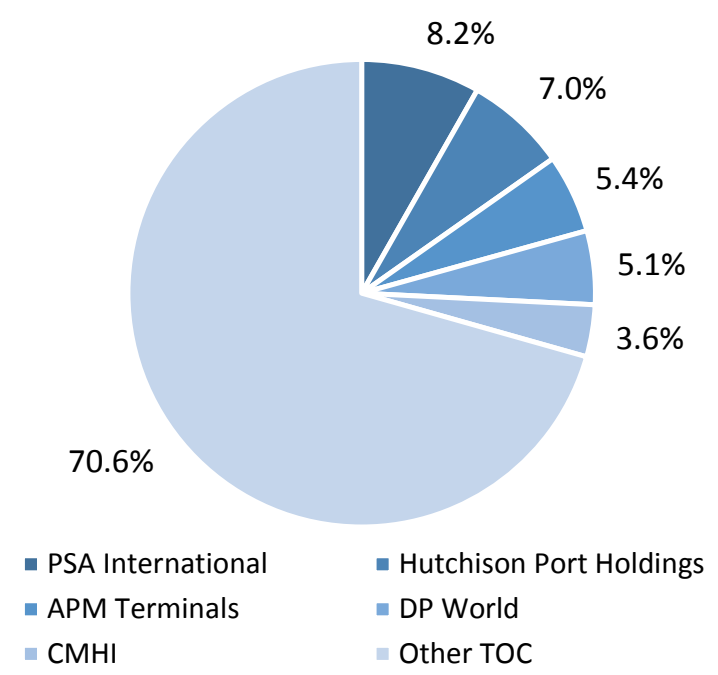

Source: Drewry Shipping, Top TOC 2014

\footnotetext{
${ }^{13}$ Alphaliner Top 100 - operated fleets as of October 142015 http://www.alphaliner.com/top100/

${ }_{14}$ Blog published by Yann Alix https://www.linkedin.com/pulse/analyse-du-top-20-des-compagnies-maritimes-deconteneurs-yann-alix?trk=prof-post

${ }^{15}$ Based on equity shares in the various terminals, i.e. if the equity share in a terminal is $50 \%$, only $50 \%$ of its throughput is counted
} 
22. The main terminal operators and shipping lines active in West Africa are also highly concentrated (Figure 5). Bolloré Logistics Limited (BAL) and APM Terminals control $44 \%$ and $34 \%$ respectively of the container throughput in the West African container market, bringing their joint share to just below $80 \%$. The high level of concentration in West Africa compared to the world may be due to the small size of the market, and the more homogeneous nature of the active operators. Market concentration nevertheless confers significant market power and is a deterrent to potential entrants: this may well underlie the weak inter-and intra-port competition seen in the region and the durably high market shares of these two firms.

23. Table 1 below applies a modified WBG markets and competition policy assessment tool $^{16}$ to the port concessions market: the table lists key criteria affecting competition and outlines a qualitative profile of the West African situation. The tool provides some indication that competition in the port sector in West Africa is limited with significant market power conferred to existing firms and limited ability to attract new entrants. Further analysis is needed to assess how this situation is affecting the efficiency and competitiveness of the sector and to determine what policies could improve competition in the most effective way.

Figure 5: Share of Main Shipping Lines ANd TeRminal Operators in WeSt Africa

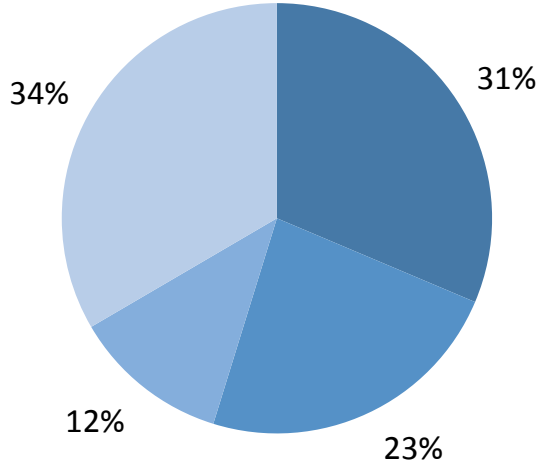

Maersk $\square$ CMA CGM $\square$ MSC $\square$ Other lines

Source: Capacity deployed in 2014, from Drewry data, prepared by ECORYS

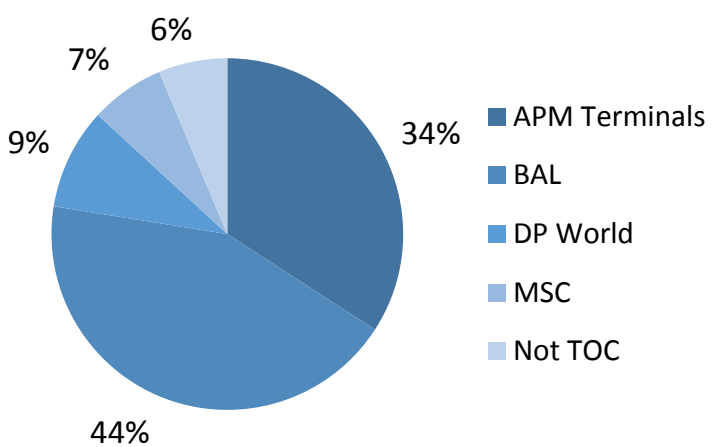

Source: Authors calculation from container throughput in 2013, reported by port authorities

TABLE 1: Key MARKET CONDITIONS IMPACTING COMPETITION IN THE PORTS SECTOR

\begin{tabular}{|l|l|l|l|}
\hline Criteria & Comments & Situation in West Africa & Check \\
\hline
\end{tabular}

\footnotetext{
${ }^{16}$ For more information on how this toolkit is applied, refer notably to: Promoting Faster Growth and Poverty Alleviation through Competition- Competition in South Africa Cartels, The World Bank Group. February 2016. http://wwwwds.worldbank.org/external/default/WDSContentServer/WDSP/IB/2016/02/02/090224b08412c4ae/1 0/Rendere d/PDF/SouthOAfrica0e00through0competition.pdf
} 


\begin{tabular}{|c|c|c|c|}
\hline Concentration levels & $\begin{array}{l}\text { Competition is severely limited } \\
\text { when there are few firms in the } \\
\text { market allowing participating } \\
\text { firms to monitor competitor's } \\
\text { actions }\end{array}$ & $\begin{array}{l}\text { At present, there are two } \\
\text { operators which together } \\
\text { control } 80 \% \text { of the total } \\
\text { container market }\end{array}$ & $\square$ \\
\hline $\begin{array}{l}\text { High barriers to } \\
\text { entry }\end{array}$ & $\begin{array}{l}\text { In the case where there are } \\
\text { collusive prices, these act as an } \\
\text { incentive for new entrants; } \\
\text { high barriers however prevent } \\
\text { entry, making It easier to } \\
\text { sustain limited competition }\end{array}$ & $\begin{array}{l}\text { Though sunk costs in existing } \\
\text { terminals are modest, most } \\
\text { contracts have long durations } \\
\text { providing effective entry } \\
\text { barrier. Political connections of } \\
\text { incumbent firms are also an } \\
\text { advantage. }\end{array}$ & $\square$ \\
\hline $\begin{array}{l}\text { Homogeneous } \\
\text { products }\end{array}$ & $\begin{array}{l}\text { Competition is facilitated and } \\
\text { monitoring is harder with } \\
\text { differentiated products }\end{array}$ & $\begin{array}{l}\text { Container handling is an } \\
\text { homogeneous product } \\
\text { worldwide }\end{array}$ & $\nabla$ \\
\hline Cross ownership & $\begin{array}{l}\text { Having any degree of } \\
\text { participation with a competitor } \\
\text { increases the risk of collusion. } \\
\text { It makes information exchange } \\
\text { and price coordination easier. } \\
\text { It also reduces the incentives to } \\
\text { compete in the marketplace. }\end{array}$ & $\begin{array}{l}\text { In West Africa and Central } \\
\text { Africa, the dominant TOC's are } \\
\text { also jointly operating terminals } \\
\text { (Tema, Abidjan } 1 \text { and } 2 \text {, } \\
\text { Douala, Pointe Noire) } \\
\text { Different forms of integration: } \\
\text { operational, financial and } \\
\text { contractual (as in joint } \\
\text { ventures) are all present in the } \\
\text { port sector in West Africa. }\end{array}$ & $\nabla$ \\
\hline Regular orders & $\begin{array}{l}\text { The high frequency of orders } \\
\text { increases the risk of collusion } \\
\text { because it allows for timely } \\
\text { punishment in case of } \\
\text { deviation, since the infringer } \\
\text { will not risk losing regular } \\
\text { collusive profits }\end{array}$ & $\begin{array}{l}\text { Not applicable: } \\
\text { Contracts between shipping } \\
\text { lines and TOC are generally for } \\
\text { long periods } \\
\text { There are no contractual } \\
\text { arrangements per se between } \\
\text { TOC and shippers }\end{array}$ & \\
\hline Symmetric firms & $\begin{array}{l}\text { Mutually advantageous } \\
\text { agreements are easier to reach } \\
\text { and sustain for firms with equal } \\
\text { bargaining power. }\end{array}$ & $\begin{array}{l}\text { The market is more or less } \\
\text { equally divided between the } \\
\text { main operating companies } \\
\text { conferring equal bargaining } \\
\text { power to each. }\end{array}$ & $\square$ \\
\hline Inelastic demand & $\begin{array}{l}\text { In case of collusive practices, } \\
\text { demand elasticity affects the } \\
\text { level of the maximum collusive } \\
\text { price. }\end{array}$ & $\begin{array}{l}\text { Demand from shippers would } \\
\text { be relatively inelastic as most } \\
\text { countries have a single CT. }\end{array}$ & $\nabla$ \\
\hline $\begin{array}{l}\text { Inventories and } \\
\text { excess capacities }\end{array}$ & $\begin{array}{l}\text { If firms are endowed with large } \\
\text { capacities or excess inventories } \\
\text { they might have incentives to } \\
\text { reduce production }\end{array}$ & $\begin{array}{l}\text { By nature, transport } \\
\text { infrastructure has excess } \\
\text { capacity. }\end{array}$ & $\square$ \\
\hline
\end{tabular}




\begin{tabular}{|l|l|l|c|}
\hline $\begin{array}{l}\text { Multi-market } \\
\text { contracts among } \\
\text { firms }\end{array}$ & $\begin{array}{l}\text { The same firms meeting in } \\
\text { different markets could } \\
\text { facilitate collusion }\end{array}$ & $\begin{array}{l}\text { Shipping lines and TOCs are } \\
\text { vertically integrated, including } \\
\text { provision of inland logistics. }\end{array}$ & \\
\hline
\end{tabular}

24. Buyer power of downstream operators, such as shipping companies, can be a powerful way to compensate for the market power of port services providers, although this is not the case in West Africa due to the high degree of vertical integration of the leading operators and their strategic partnerships with the major shipping lines active in the region (e.g. Maersk and APM Terminals). Joint control over the major container terminals along the coast also reduces the possibility for users to switch to rival services, although the presence of competitors in some ports, such as Dakar, Lomé and San Pedro, may provide some leeway for this. Whether the entry of a small number of new players will result in an intensification of competitive pressures or an alliance with historical operators is still unclear and will require monitoring in the future.

25. Container handling charges generally appear to be quite high in the region. A systematic analysis of the market power of TOCs in West Africa and its consequences is needed to understand the welfare implications of the price and service quality offered by operators. Excessive market power by terminal operating companies creates a risk of abuse of their dominant position. Some broad calculations (presented later) indicate that returns are far higher than indicated to compensate for difficult local conditions and the risk taken by operators. In a parallel situation, which concerns the shipping lines and their respective stevedoring subsidiaries and not the terminal operator per se, the de facto monopoly established by the stevedoring companies for container deliveries in the Abidjan metropolitan area excludes smaller transport companies from the market, and their market power seems to have enabled operators to set excessively high prices for captive customers ${ }^{17}$.

26. Insufficient transparency and the structure of port tariffs make comparison across ports and regions difficult, but the trading across borders of the Doing Business indicators can be used as a proxy for estimating port handling costs. The challenge of collecting tariffs that are frequently not widely published beyond the immediate port community is compounded by the facts that sometimes container handling is charged indirectly to the shippers (for instance through THC -Terminal Handling Charges - or partly included in the sea freight according to the liner terms) and that tariff structures differ in tariff items and in special conditions. Fortunately, the World Bank Doing Business indicators monitor the cost of trading across borders worldwide. The indicators record the time and cost associated with the logistical process of exporting and importing goods. Under the new methodology introduced in 2015, Doing Business measures the

\footnotetext{
${ }^{17}$ A similar monopoly was in place at the port of Dakar, but the port authority took resolute action to introduce competition in the container delivery activity, which resulted in a price reduction. Ivoirian authorities are now also seeking to address the problem in Abidjan.
} 
time and cost (excluding tariffs) associated with three sets of procedures: documentary compliance, border compliance and domestic transport ${ }^{18}$. In the case of coastal countries, the cost of border compliance corresponds to port handling and customs clearance at the port, and for landlocked countries, the cost of border compliance corresponds to handling and inspections at the land border crossing, by nature less costly.

FigURE 6: COST OF BORDER COMPLIANCE, DOING BUSINESS 2016 INDICATORS, WORLD BANK

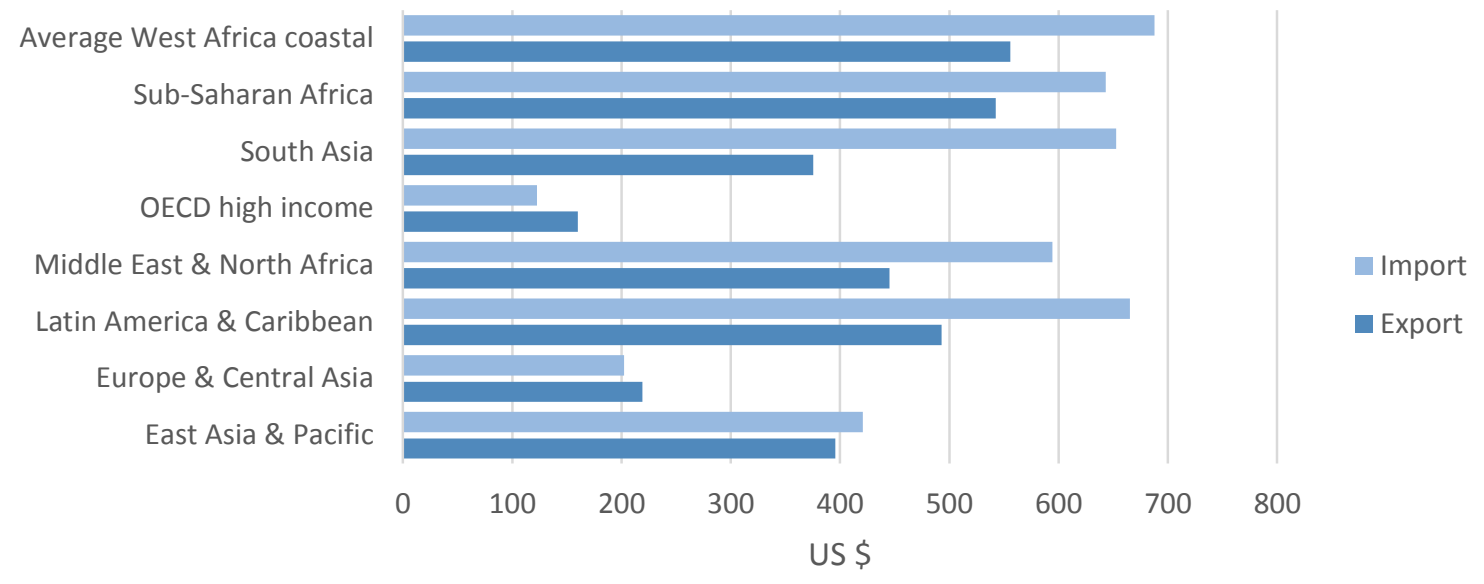

27. At regional level, Sub-Sahara Africa has the highest Border Compliance costs (when combining import and export) among all regions. In Figure 6 the average cost of border compliance has been calculated for West Africa coastal countries in order to compare only port related costs. A regional comparison shows that South Asia and the Latin America \& Caribbean have slightly higher border compliance costs to import, but much lower border compliance costs to export, which confers a competitive advantage to their exports. The cost of border compliance for Coastal West Africa is higher than the Sub-Sahara Africa average, and therefore higher than all other regions, for both imports and exports. The costs of border compliance at ports in the Coastal West African countries are dispersed widely, ranging from \$786 to \$1,077 for a 20' container for imports, and $\$ 163$ to $\$ 786$ for exports. A further breakdown by countries where container terminals are under concession and countries without concessions shows a consistent trend of higher costs for concessioned terminals. In Figure 7, the lowest portion groups the ports managed by TOCs (i.e. Togo to Benin), while the top shows ports without concessions. The cost profiles are quite contrasted: In ports without concessions, the difference between import and export costs is minimal and in three out of four countries, it is more expensive to export than to import. In ports with concessions, handling charges for imports are $32 \%$ higher than for ports without concessions. As indicated earlier, traffic in West Africa is imbalanced, with import flows

\footnotetext{
${ }^{18}$ For further information on the methodology, see http://www.doingbusiness.org/methodology/trading-across-borders
} 
dominating. In ports under concession, TOC are applying differentiated tariffs, and the cost to import is $41 \%$ higher than the cost to export.

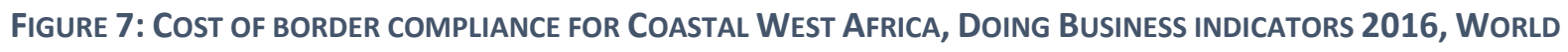
BANK

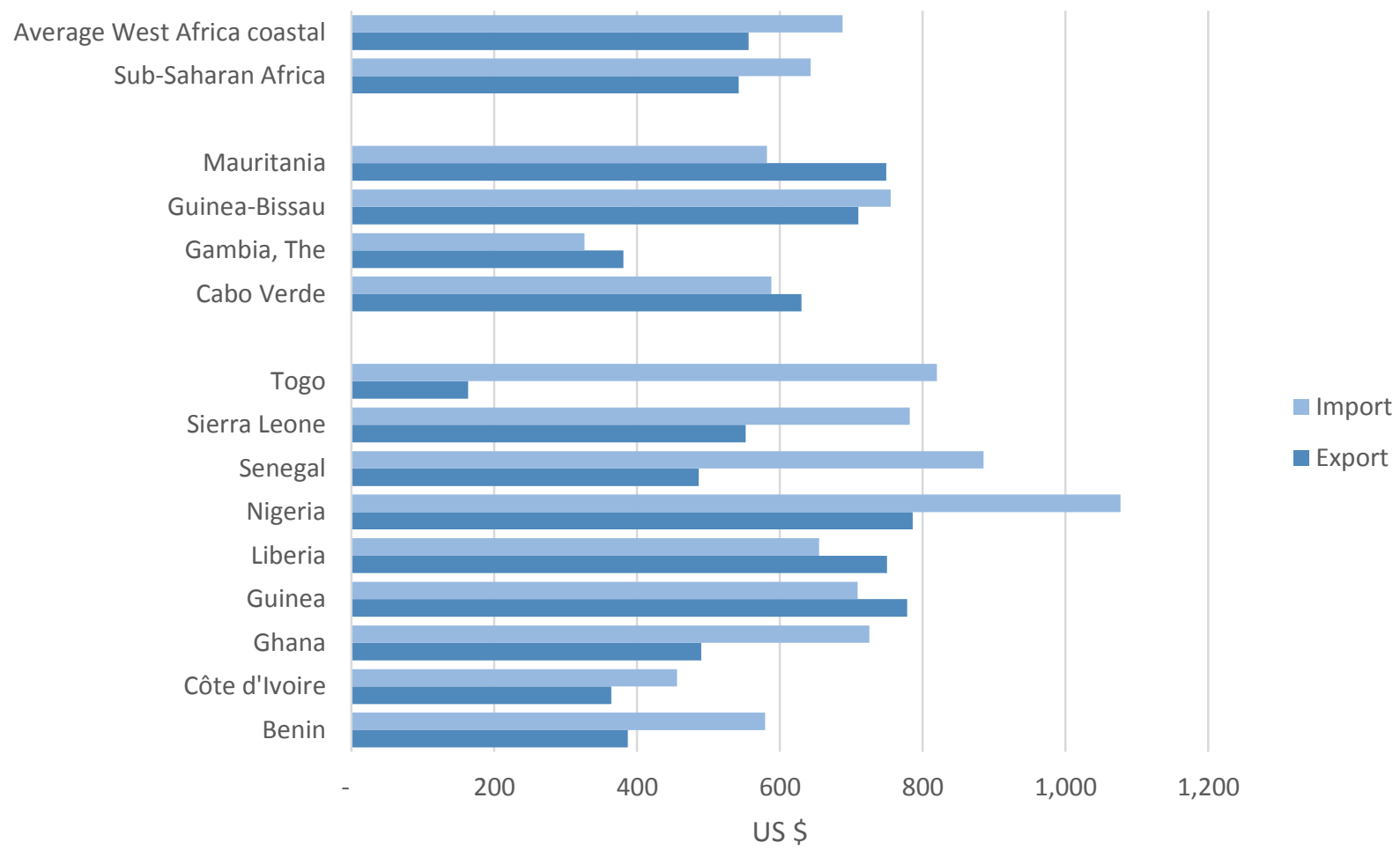

28. Shipping lines and shippers, the main customer groups of container terminals, are concerned with three types of risks in their use of port services. Without effective public policies, port authorities and terminal operators may not have adequate incentives to provide the highest level of service (operational efficiency, notably handling performances), provide adequate facilities, or guarantee the lowest price (Table 2). For container traffic, shipping lines and shippers are not exposed to these risks to the same degree. For shipping lines, operational efficiency is often more important than price, because whether chartered or not, ship delays cost money to the line and endanger schedule reliability, which is an important marketing asset. Shippers are indirectly affected by terminal operational efficiency, as poor performance can lead to congestion at the terminal, delaying shipments and incurring various congestion surcharges. However, shippers are more exposed to price risks, particularly as they often have little say in the selection of the port or terminal which influences the shipper's costs. The port or terminal selected is linked to the selection of the shipping line in the case of multiple terminals in a port, or even more remotely, by the choice of the logistic chain (in which the shipping leg is one component of a more complex succession of nodes and modes) which determines the port. 
TABLE 2: Differential RISKS to CT CUSTOMERS

\begin{tabular}{|lccc|} 
& Performance Risk & Inadequate facilities & Price Risks \\
\hline Shipping lines & Moderate & Moderate to high & Low \\
\hline Shippers & High & Low & High \\
\hline
\end{tabular}

29. Shipping lines are primarily interested in fast access to berths and the fast handling of ships. Maintaining a weekly service on a trade lane with many ports of call means that schedule integrity is critical not only to the customers (the shippers), but also to the lines themselves. To avoid congestion at terminals and pre-berthing delays, many ports have adopted a window berthing system, in which a ship is guaranteed priority access to a berth provided it arrives at the port within a pre-defined period of time (the window), replacing the more traditional first-come, first-served rule. Waiting to access a berth can cause snowballing delays, since the ship may then miss the window in the next port of call. With ships costing in the range of US\$10,000 to US\$12,000 a day depending on the size (for 2,000 TEUs to 3,500 TEUs vessels), shipping lines tend to include as many ports as possible in the loop with the minimal number of vessels, leaving little time to make up for accidental delays. To avoid delays at berth, terminals have upgraded the handling equipment, switching from ship's gear to gantry cranes, in order to improve the number of moves they can deliver per hour of call.

30. In addition to quick turnaround of their vessels, shipping lines also expect ports to accommodate the ever-larger ships required by traffic growth. Larger vessels are more cost efficient than smaller vessels. In practice, however, the total annual volume of trade, the number of competing shipping lines, and the nautical characteristics of the ports included in the loop tend to define the optimal ship size and characteristics to be deployed. The capacity of the container vessels servicing WAC ports ranged between 1,500-3,000 TEUs in the early 2000's has increased steadily over the time to range nowadays between 4,000-5,000TEUs. The largest shipping lines present on the West Africa trades (Maersk Lines, CMA-CGM and MSC) usually operate several weekly services combining different ports into different loops, in an effort to optimize the relationship between vessel characteristics and trade size, under the constraint of nautical and terminal characteristics.

31. Shipping lines have some flexibility to mitigate the negative consequences of inadequate services such as long turnaround times or access limitations. Global terminal operators and major shipping lines have more or less equal power, and negotiations are generally conducted between equal partners. Contractual arrangements include service level agreements that define minimum productivity levels, with possible penalties if performance is below the agreed standards. In the worst case scenario, shipping lines can also reduce their exposure to risks by removing the port / terminal from its mainline schedule and serving it through feeder services, or shifting the port to a less time-sensitive loop (which is only possible when the shipping line offers a range of services). The reorganization of the liner shipping networks on the 'hubs 
and spokes' model divided ports into several classes, with some ports serving as transshipment platforms, on a global or regional scale, and others serving localized hinterland markets through regional/local feeders. Shipping lines can therefore isolate a poorly performing port while still retaining the possibility to serve its market. Such measures are costly, however, and therefore can only be a solution when the threshold of tolerable underperformance has been passed. Nevertheless, the ability of shipping lines to switch their operations between ports does constitute a form of competition between ports.

32. Most ports aspire to the status of global or regional hubs, and are eager to appease the shipping lines. National aspirations continue to be fueled by the perceived advantages of additional traffic generated by the double handling of containers, the competitiveness boost from direct access to trunk liner services and, if the conditions are right, the possibility to convert the connectivity advantage into a catalyst for economic activity, for instance by establishing special economic zones. However, the position of a hub is fragile compared to that of a gateway port due to the fickle nature of transshipment traffic, intense competition and risk of aggressive pricing from rival hubs. There are indeed several examples of carriers rapidly shifting large volumes of cargo from an initial hub to a more competitive one ${ }^{19}$. This risk is higher for specialized ports established as pure transshipment platforms, compared to more diversified hubs with a mix of transshipment and local traffic. Hub strategies pursued by ports need to be predicated on obtaining a long-term commitment from a carrier to use the facility, involving one or several carriers in the equity structure of the new facility, and developing landside connections to secure more hinterland traffic. Even so some studies have encouraged caution about the potential effects of inter-port competition between countries for hub status in a context of limited scope for transshipment. The desire to attain hub status led to a detrimental political race along the pacific coast of South America when countries would have benefited more from greater regional coordination of transport policies and investments in port and land transport infrastructure (Hoffmann 2000). As noted in Chapter one, changes in the shipping industry have created an opening for one or more regional hubs on the West African coast. Shipping lines have been exploring options for some time with Lomé, Lekki, Abidjan, Tema, Douala, Badagary still all in play for the coveted position. It is expected that the shipping lines will determine sooner rather than later which of these will be taken forward as hub locations (i.e. already executed for Lome). Such terminal developments are negotiated concessions, and it is therefore important for Governments and port authorities to negotiate beneficial conditions for the economy of the country at the early stages.

33. Because they can make or break the fortune of the ports, shipping lines tend to have the upper hand in their interaction with ports and terminal operators. The choice by MSC of

\footnotetext{
${ }^{19}$ In 2000, Maersk Lines shifted its operations from Singapore, including its regional transshipment to the newly developed terminal at Port of Tanjung Pelepas (PTP), in which it had acquired a 30\% stake. The volume represented an activity of 2 million TEUs a year for PTP
} 
the Port of San Pedro in Cote d'Ivoire as its West Africa transshipment hub added up to 180,000 TEUs of transshipment traffic at its peak (Figure 8), coupled with some positive impact on the gateway trade; the traffic of the port multiplied by more than four. When MSC shifted its regional hub for the Asia trade to Lomé at the end of 2014, it reorganized its entire Asia - West Africa trade service to concentrate all traffic on Lomé, the only port in West Africa able to accommodate the vessels it deployed on the service. That reduction of the number of calls in West Africa enabled MSC to reduce the fleet required by a weekly service to 10, replacing all other calls by a network of feeder services. Lomé therefore experienced a surge in its activity: statistics for the year $\mathbf{2 0 1 5}$ for the port of Lomé show that gateway (domestic and transit) traffic increased by a mere 2\%, whereas transshipment multiplied by almost 5, compared to the year 2014 . Consequently, transshipment activity in San Pedro dropped.

Figure 8 : Port of SAN PEDRo, GRowth OF CONTAINeR tRAFFiC

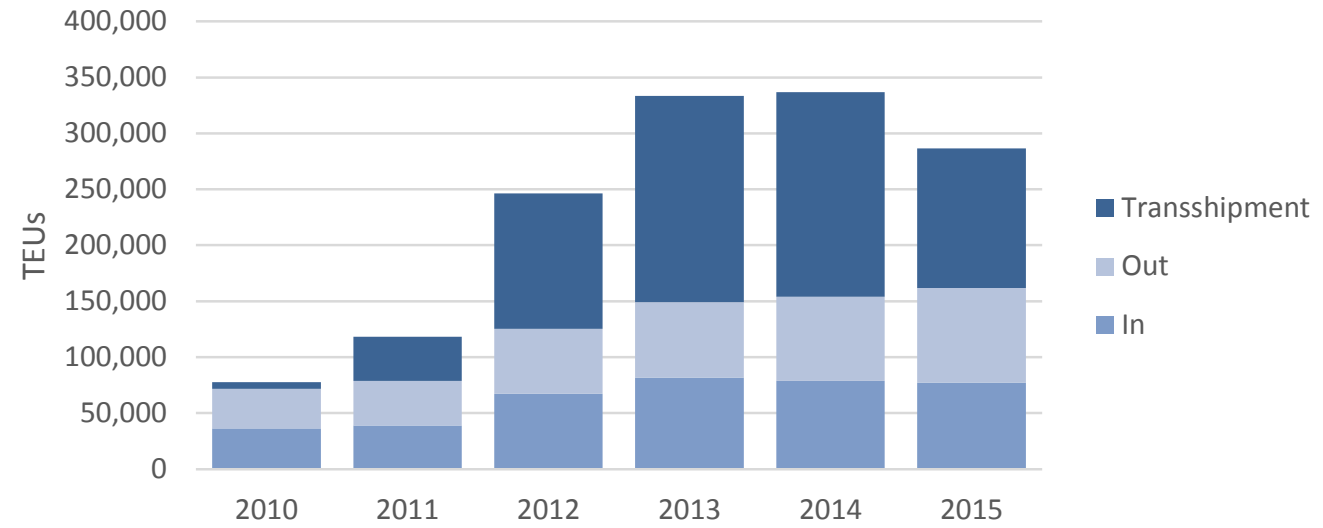

34. The interaction between shipping companies and TOCs is also affected by the fact that some global TOCs are part of the same group as the shipping lines they serve. APM Terminals is the terminal operating arm of Maersk Lines, TIL of MSC, and when Delmas shipping was acquired from the Bolloré group by CMA-CGM in September 2005, the two groups signed an agreement which guaranteed that Delmas services will continue for five years (therefore throughout the first wave of container terminal concessions) to use Bolloré's inland logistics, including stevedoring services. Control of inland logistics appears at present to be the only way for a line to guarantee quality of service and, critically, delivery times, for door-to-door consignments. As such this is an area where integration is helpful and unbundling might be counter-productive. The situation will continue as long as the inefficiencies of the trucking industry persist. As a consequence, shipping lines tend to favor ports in which they control the inland logistics, and this is one of the drivers of the expansion plans for the ports in West Africa.

35. Shippers have far less service options than shipping lines and far less bargaining power, and therefore face greater risks, particularly in terms of arbitrary tariffs. Shippers are largely captive customers of the ports and terminals, and have little or no influence on the prices for 
port services. Most of the port activities have a high fixed cost component, and tariffs are often designed to guarantee that traffic multiplied by tariffs indeed covers all costs (operating and investment). Any traffic increase is therefore generating a proportional increase in revenue, while the corresponding increase of the variable portion of the costs is much less if the increase does not imply a discrete investment in additional handling equipment or infrastructure. This mode of definition of the tariffs offers the possibility to have differentiated tariffs. For instance, it is common to have per TEU prices, when in practice there is no significant difference between handling a 20'-foot container or a 40'-foot container (although storage does require double the space). It is also common to have a lower price for export containers than for import containers. Moreover, even when there are multiple operators, prices tend to be set by professional associations, so that prices are identical irrespective of the provider.

\section{BOX 2: PORT FEES, PRICES AND SERVICES}

The maritime gateway processes are complex, due to the number of agencies and operators involved, the nature of the documentation processes conducted, and the combination of physical and information flows involved. It is important to ascertain which fee is paid by whom in order to avoid double counting (for instance, what is paid by the ship is ultimately built into the freight rate paid by the shipper), and also to separate what is related to transport and logistics from what is related to trade tariffs (Customs duties and VAT, and also PSI / DI certification). Prices for logistics services at the maritime gateway are listed in the table below:

\begin{tabular}{|c|c|c|}
\hline & Paid by ship & $\begin{array}{l}\text { Paid by the shipper } \\
\text { (through C\&F agent) }\end{array}$ \\
\hline Nautical services & $\begin{array}{l}\text { Pilotage, towage, } \\
\text { and mooring }\end{array}$ & \\
\hline Port Authority & Ship dues & Cargo dues \\
\hline $\begin{array}{l}\text { Cargo handling } \\
\text { companies / } \\
\text { Terminals }\end{array}$ & $\begin{array}{l}\text { Shifting / re-stow of } \\
\text { containers to access } \\
\text { containers, } \\
\text { transshipment, and } \\
\text { also loading of } \\
\text { empty containers }\end{array}$ & $\begin{array}{l}\text { Container handling, from ship to yard or } \\
\text { warehouse, then to yard or warehouse to } \\
\text { vehicle, with sometimes additional } \\
\text { intermediate movements, such as positioning } \\
\text { for physical or non-intrusive (scanner) } \\
\text { inspection by border management agencies, } \\
\text { and also, beyond a certain grace period, } \\
\text { storage fees }\end{array}$ \\
\hline $\begin{array}{l}\text { Clearing and } \\
\text { Forwarding } \\
\text { (C\&F) agents }\end{array}$ & & $\begin{array}{l}\text { Documentation processing by the Clearing } \\
\text { and forwarding agents (C\&F agents) } \\
\text { Payments for Customs duties (for destination } \\
\text { clearance) or mobilization of the guarantee / } \\
\text { bond for transit }\end{array}$ \\
\hline Shipping agents & & $\begin{array}{l}\text { Delivery order (DO), B/L fees, deposits for } \\
\text { container removal }\end{array}$ \\
\hline
\end{tabular}

\footnotetext{
${ }^{20}$ There are possible variations from this base scenario, with for instance transfer of the containers into a dry port in the port vicinity, or additional handling for consolidating / stripping containers in port and loading / offloading vehicles
} 

Other agencies
PSI / DI certification, Shippers' councils Cargo
Tracking Notes, etc.

For terminals, the main tariff items are (i) quay handling, (ii) storage, and (iii) loading / offloading of the vehicle.
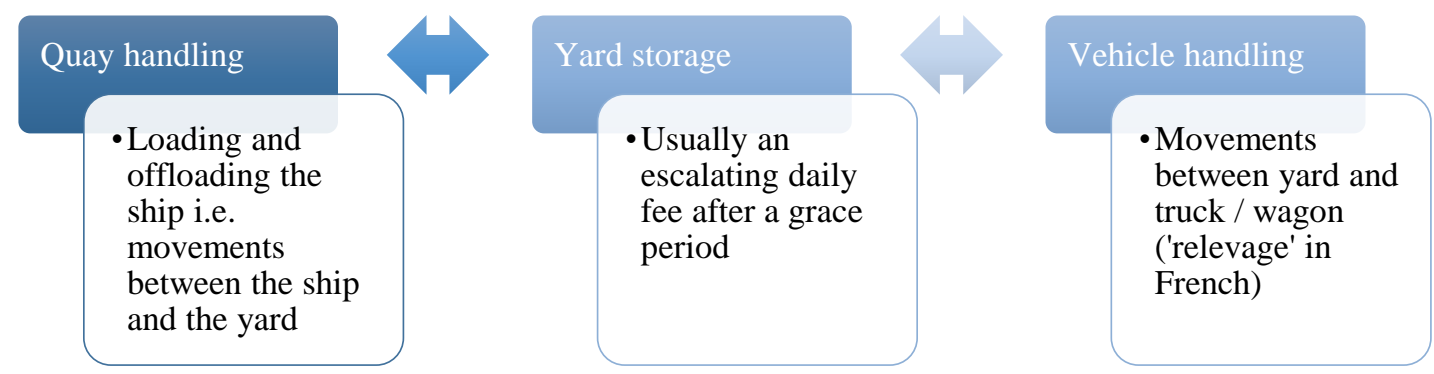

\section{The "Naturally Monopolistic" Container Terminal Market of West Africa and competition for the market}

36. Ensuring adequate competition in port services in the context of high concentration in TOCs and shipping services is a complex task. One approach is to encourage competition 'in the market" by promoting intra-port competition, and if that is difficult to achieve, attention should be focused on inter-port competition. The second alternative is to promote competition 'for the market" (through concessions), with adequate attention to economic regulation, ${ }^{21}$ supplemented with competition in the non-monopolistic services needed for the functioning of the CT and the ports. Competition for the market and regulation are discussed in Chapter 3 while the status of competition in the market is taken up below. ${ }^{22}$

37. Intra-port competition existed, at least on paper, in most of the West Africa ports prior to the creation, and concession, of the container terminals. Prior to the wave of CT concessions, the stevedoring business had been opened to licensed operators. For instance, in Tema, the monopoly on stevedoring held by the Ghana Ports and Harbours Authority (GPHA) was abolished, and licensed stevedores were handling 75 percent of the traffic, with GPHA handling 25 percent. The creation of container terminals and their concessioning replaced several operators by one single terminal operator. To continue with the example of Tema, while MPS, the terminal operator, handled the majority of the container traffic at the port, stevedoring companies still obtained a share of the traffic providing a level of intra-port competition. This was removed when GPHA was granted exclusive rights to handle ships with a call volume over 50 containers. In West African ports with terminal concessions, only a few ports have maintained plurality in container handling: Cotonou, where COMAN (a subsidiary of APM Terminals) handles container vessels,

\footnotetext{
${ }^{21}$ See the OECD Policy Round Table on Competition in ports and port service, December 2011 available at http://www.oecd.org/regreform/sectors/48837794.pdf

${ }^{22}$ See Klein (1996) for a taxonomy of approaches to encouraging competition in natural monopolies.
} 
Lagos, with two container terminals (Apapa and Tin Can Island) and Lomé, also with two container terminals (Togo Terminal and LCT). In all other ports, containers are handled in a single terminal.

38. Only a few ports in West Africa have sufficient throughput to sustain more than one terminal, and even fewer have the facilities that would enable the creation of two terminals. Because of economies of scale, assessing the benefits of one efficient terminal with a monopolistic position versus two (or more) less efficient terminals with the possibility of competition is only useful when traffic volumes reach a minimal threshold. If volume is the primary criteria to determine the viability of multiple container terminals, the layout of the port is also an important parameter to consider. In most ports, only a few berths have physical characteristics suitable for handling container vessels: sufficient draft, backspace to create a container yard, sufficiently strong quay walls to accommodate gantry cranes, etc. It is therefore very likely that only one location in the port is suitable for a container terminal, not more. In the first wave of concessions, only Lagos met the necessary criteria to have two different container terminal concessions.

39. Observed growth in containerized traffic is gradually leading to saturation in some facilities, so that it becomes necessary to consider whether new capacity can be used to promote competition, for example by leasing a new terminal to an operator other than the one responsible for the existing terminal. However, the port authorities in West Africa have not always taken up this opportunity. In Abidjan, for example, the second terminal was ultimately awarded, after a competitive process, to a group comprising the same TOCs as the first terminal; in Tema, the concession of the existing terminal was simply expanded to include the new infrastructure to be developed. Lomé is an exception, with the existing container berths awarded to one operator, while the second terminal, primarily serving MSC vessels and created through a BOT, was awarded to a different operator.

40. If introducing intra-port competition is infeasible, government should promote substitutability between ports and thus create inter-port competition. The issue differs considerably between shipping lines and shippers, as has been discussed in the section above. The major shipping lines have considerable market power, and enjoy significant flexibility in structuring services, so they tend to be less disadvantaged by the market power of TOCs. Shippers, on the other hand, are far more dependent, and it is only for shippers located in the hinterland that alternatives exist. Transit traffic is therefore the only disputed portion of the traffic, and it benefits from a preferential treatment that the captive shippers do not enjoy.

41. In practice, due to the results of the terminal concession awards, there is little interport competition in West Africa. The main maritime gateways for the three West Africa landlocked countries are Dakar, Abidjan, Tema, Lomé, and Cotonou. In addition to the main five ports, Takoradi had played a minor role for transit to Burkina Faso at the height of the crisis in 
Cote d'Ivoire, and San Pedro and Conakry handle small transit volumes for Mali. Out of the five main transit ports, BAL is present in all of them (although only for the Ro-Ro terminal in Dakar), and APM Terminals is present in three (Tema and Abidjan as shareholder in the container terminals, and Cotonou through its stevedoring subsidiary).

42. The rapid progress of containerization and inland logistics have standardized port operations and facilitated intermodal transport, making many ports closer substitutes competing for larger hinterlands and thus considerably shrinking the size of the undisputed hinterland. Ports are just one node in the complex logistics chains for international shipping trade. Nevertheless, the relative costs, times and risks between maritime transport and land transport mean that in practice, ports have an undisputed hinterland of variable extent, and only beyond a certain distance can it become economically viable for shippers to consider an alternative port. In this context, the decision for shippers to use a particular port to reach a given inland destination is a function of a range of criteria identified in the port choice literature, including costs and prices, terminal characteristics and performance, shipping connectivity and access to hinterland, complexity of the documentation process, etc.

43. Most West African ports, however, have retained large undisputed hinterlands, due notably to the persistence of numerous obstacles to trade and transport on the landside. In practice, coastal countries rely almost exclusively on domestic ports for their imports and exports. The two notable exceptions are the large transit to Nigeria passing through the port of Cotonou, but this is mostly due to restrictive trade policies in Nigeria, and the clinker passing through the port of Lomé for Ghana, but this is justified by the location of the cement factory ${ }^{23}$, just on the other side of the border and therefore only a few kilometers from the port. Except for these very specific cases, inland transport inefficiencies very quickly constitute a barrier that keeps the hinterland of the West Africa ports largely disjointed: advanced logistic services are in their infancy, for instance in terms of intermodal transport, warehousing and dry ports; the West Africa trucking industry is mostly comprising informal and non-professional operators with inefficient practices (e.g. container stripping at the port, opaque access to freight through a series of intermediaries, dilapidated truck fleets and no capacity to invest in efficient vehicles); and long border crossing times and frequent roadblocks contribute to increasing the cost of importing through a port located in a neighboring country.

44. Lengthy and complex processes to trade across borders also help maintain a large, undisputed domestic hinterland for ports. Some policies directly aim at discouraging traders from using ports in neighboring countries and thus at restricting inter-port competition: for instance, Ghana has banned the import of rice through land borders, which is officially justified by the prevalent smuggling of rice imported through Cote d'Ivoire, where duties and taxes on

\footnotetext{
${ }^{23}$ The Diamond Cement Ghana Limited factory produces around 35\% of Ghana needs for cement. A $2.5 \mathrm{~km}$ railway line linking the port of Lomé to the factory was opened in February 2014.
} 
rice imports were lower. And Senegal has imposed restrictions on transit from the Gambia due to concerns of smuggling and evasion of customs duty. However, the entry into force of the ECOWAS Common External Tariff (officially on January 1, 2015, although implementation difficulties remain) may reduce this concern.

45. Farther from the ports, shippers from West African hinterland countries benefit from some form of substitutability between transit corridors. Whether located in Mali, Burkina Faso or Niger, equivalent distances normally enable shippers the freedom to choose from among several corridors the one that minimizes the time, cost and risk of land transport and port operations. The degree of substitutability between ports has been illustrated in recent years by the diversion of traffic away from Abidjan due to the disruptions in the corridor caused by the political Ivorian crisis.

46. This substitutability is recognized by the ports, which conforming to classical monopolistic behavior, provide better terms to shippers from disputed hinterlands than to 'captive' shippers. Port authorities, terminal operators and shipping lines compete for transit traffic by charging lower tariffs for transit containers, granting longer grace periods to return containers from hinterland destinations, and offering longer grace period for yard storage in ports. This can be an effective strategy, and the main West Africa ports have all opened liaison offices in the hinterland countries to market their respective advantages.

47. In sum, there is a high level of concentration in the conterminal terminal market with two of the dominant firms, BAL and APMT, controlling about $80 \%$ of the total container throughput in the region. Such high levels of concentration confer significant market power for unregulated terminal services and the dominant positions, when associated with weak tariff regulations, can be strengthened when opportunities to enter the market are restricted via relatively long-lived concession contracts. Due to the small size of the majority of the ports, intraport competition has not been possible in most countries. Even where ports are able to support more than one terminal, often time the same firm has been awarded both terminals, thereby removing the element of competitive pressure on prices and operational performance. Inter-port competition is also impeded when the same two firms control terminals which might otherwise compete with each other for overlapping hinterlands and raise the issue of collusive behavior to keep tariffs near or the maximum level allowed contractually by concession agreements. This phenomenon raises the question as to the role of Governments is setting tariff policies and market regulations that can result in lower end users costs without deterring private investment even in naturally monopolistic markets like that of the TOC. 


\section{Institutional Reforms and the Governance of Container Terminal Concessions}

\section{A. The institutional framework for West African ports}

48. The institutions responsible for port management and the extent of public sector responsibilities have evolved greatly in West Africa over the last decades. While the changes have been fairly uniform at a general level, there are a multiplicity of actors and arrangements between the public authorities and the private sector at the national level. This chapter attempts to identify the potential weaknesses and uncertainties in the tendering process, contract development and management with examples and see how these could benefit from strengthened governance. The changes in West Africa mirror similar changes on the global scale and can be summarized as follows:

- In the mid-1950s, almost all ports were considered ministry departments providing public services. As such, they were under the direct responsibility of their line ministry (e.g. Transport, Infrastructure, or Maritime Affairs) and completely integrated in the central government apparatus.

From the 1970s onwards, reforms were undertaken to reinforce the autonomy and independence of port authorities.

- $\quad$ From the late 1980 s to the 1990 s, many West African ports acquired more financial independence as state-owned corporate entities, governed by private law and supervised by a board of directors. Although governments still influence the appointment of port authorities' managing directors, the board, where port users' professional associations, and frequently staff representatives, are represented in addition to line ministries, became the key decision-making body for strategic and large investment matters, resulting in a greater autonomy and independence.

- From the mid-2000s, the spread of port concessions in West Africa ${ }^{24}$ led most port authorities to depart from the "service port model", in which they are responsible for infrastructure and services, to become "landlord ports" with a focus on core strategic and regulatory functions.

49. Despite the general move towards the landlord port model ${ }^{25}$, the institutional structure for port management in West Africa differs across countries. In Anglophone countries, a

\footnotetext{
${ }^{24}$ Cote d'Ivoire initiated this movement in 2004 and only Cape Verde, the Gambia and Guinea-Bissau have not established port concessions with terminal operators so far, despite discussions for several years. Existing concessions mostly concern container terminals.

${ }^{25}$ See Table 3 for public/private responsibilities under the different port models
} 
national port authority usually has jurisdiction over all the ports in the country, with varying degrees of involvement in the operations, and sometimes a regulatory role. In Nigeria, the Nigeria Port Authority (NPA) assumes both landlord and regulatory functions and provides marine and related services across Nigerian ports. In Ghana, the Ghana Ports and Harbours Authority (GPHA) acts as a landlord port in the port of Tema (with an equity share in the joint venture with private concessionaires operating the container terminal), but as a public service port in the port of Takoradi. The National Port Authority of Liberia is a state-owned corporation which manages all four ports in the country, including the Freeport of Monrovia where container operations are concessioned. In Francophone countries, on the contrary, the norm is a dedicated port authority for each port, under the autonomous port model with a higher degree of devolution of public decision-making ${ }^{26}$. Francophone countries more rarely have several ports, but some countries do, such as Cote d'Ivoire with Abidjan and San Pedro, each a separate port authority, or Guinea, with Conakry and Kamsar (a bulk ports specialized for alumina exports), also established as separate entities. In practice, most ports in West Africa have hybrid structures on the servicelandlord continuum, and there are variations in public attributions both between and within countries.

50. In addition to port authorities and terminal operators, a large number of institutions are involved in port policy and management in West Africa. First, ministerial departments (primarily transport, infrastructure, maritime affairs, and commerce) are responsible for port policy formulation, legislation and planning at the national level. They oversee the activities of port authorities and are represented on their board, which can also include representatives of the Ministry of Finance, Prime Ministry or Presidency for the public sector representatives. Agencies in charge of public procurement regulation and privatizations can also be involved in the awarding and regulation of port concessions. Second, private and public institutions and professional associations represent the interests of port users and logistics service providers and are often represented on the board of ports in several countries (Shippers' Council, professional associations of stevedores, clearing \& forwarding agents, shipping agents). Some ports, such as the Port Authority of Abidjan and the Port Authority of Dakar, have even included on their Board representatives of the landlocked countries they serve. Finally, port users' communities have been established in several ports, with a consultative role. In the case of Abidjan, the port community is a forum comprising the Port Authority, Customs administration, professional associations, and a number of other institutions and representatives of landlocked countries.

51. The reform of the port industry in SSA, as in the rest of the world, has been driven by the growth of world trade and the spread of containerization. The emergence of global value chains and the dramatic growth of the world trade in manufactured goods coincided more or less with the transformation of liner shipping into an industry driven by a quest for efficiency. Ports

\footnotetext{
${ }^{26}$ Even in the case of autonomous ports, central governments usually retain significant control for major decisions, notably for the terminal concession process.
} 
could not remain unaffected by such changes, and had to restructure to face new challenges. In parallel, the port industry responded to a widespread movement towards increasing the role of the private sector in the provision of commercial services traditionally under the public sphere. The two forces resulted in the transformation of ports from pure public entities to an area where the public and private sector cooperate in delivery of infrastructure and services.

52. The degree and manner of private engagement in the port sector varies with local conditions (social, economic, political, cultural, geographic, etc.), and different models of inclusion and administration have proved to be efficient. It is stressed by international agencies such as the World Bank (2007), and borne out by experience, that private sector participation is not a panacea in itself but only one option out of several for port reform. All of these options need to be accompanied by other measures, such as strategic planning, institutional, legal, regulatory, and labor reforms. The new paradigm of port management seeks higher levels of performance from managing ports as business entities rather than as bureaucracies. In this worldview, archetypical port management models may be classified by the degree of private participation (Table 3): public service port, tool port, landlord port and private ports. There are no private ports in SSA, and ownership of assets and regulation of the sector remains entirely with the public sector. The landlord port model dominates the scene, though the approach is far from uniform. "Landlord ports" continue to dabble in some operations, in particular those related to provision of marine services.

Table 3: Private Sector Participation in the Port Sector

\begin{tabular}{|c|c|c|c|c|}
\hline & Infrastructure & $\begin{array}{c}\text { Cargo Handling } \\
\text { Equipment }\end{array}$ & $\begin{array}{l}\text { Stevedoring } \\
\text { services }\end{array}$ & Marine Services \\
\hline $\begin{array}{l}\text { Public Service } \\
\text { Port }\end{array}$ & Public & Public & Public & Public \\
\hline Tool Port & Public & Public & Private & Public \\
\hline Landlord Port & Public & Private & Private & Private \\
\hline Private Port & Private & Private & Private & Private \\
\hline
\end{tabular}

Source: Adapted from World Bank Port Reform Toolkit (2007)

\section{B. Port Concessions in West Africa}

53. It is broadly recognized that concessions can be used to encourage competition in naturally monopolistic markets. Demsetz (1968) suggested that competitive bidding can be used to award monopoly contracts between a government entity and the most efficient supplier, to try to replicate the outcomes that would emerge in a perfectly contestable market. The main idea is that the power of competitive markets can be exploited at the ex-ante contracting stage, even though ex post there is only a single firm in the market. Ex post, regulation effectively takes place via the terms and conditions of the contract which have been agreed following the 
competitive process. The bidding process can always be refined with additional criteria to reflect the context and requirements of the contracting authority.

54. The contracting system must however meet certain conditions to mimic the results of contestable markets. The key conditions are that there be, at the very least, an adequate number of ex ante competitors and that they act independently of each other, that is, there should be no collusion. As firms have differing access to productive resources and information, competition among potential suppliers is likely still to be imperfect. The efficiency and rent distribution outcomes of the competitive process will also depend on the specific rules used to select the winner and the distribution of information about costs and demand among the bidders (Klemperer 2002). It is recognized that the selection criteria used to choose the winner are likely to be influenced by various political economy considerations. Where sunk costs are an important component of total costs, for example in greenfield port investments, longer duration contracts are most likely to support efficient investments in long lived assets and efficient prices for the associated services. But where the sunk costs are relatively small, as in the majority of the first wave concessions for container terminals in West Africa, repeated, short term contracts are likely to produce better results. Contracts under implementation in West African container terminals, on the other hand, tend to be long term, ranging between fifteen to twenty-five years.

55. The first wave of concessions - the brownfield concessions - for container terminals in West Africa spanned the period 2004 to 2010, and greatly modified the port landscape, with almost all container activity exclusively handled in specialized terminals. However, this does not mean there was a dramatic shift from public to private sector operations, as prior to the concessions, licensed private stevedores were already operating in most ports. Rather, these changes represented a rationalization of the container operations with the creation of dedicated container terminals. Indeed, the transformation of public ports into tool ports or landlord ports had started much earlier, and at the time the concessions were launched, most port authorities had already withdrawn from container handling.

56. International firms with historical ties to the West African port industry, and in some cases holding stevedoring licenses, were in an advantageous position when the concessions were announced. Seven (out of 17) of the concessions were granted on a negotiated basis, and two more were ultimately negotiated after a competitive tender failed, while the others were on a competitive basis (see table 4 below). The experience of the comprehensive port reform in Nigeria for all types of terminals (container, liquid bulk, dry bulk, general cargo) was similar, again with about half of the concessions negotiated ${ }^{27}$. Operators already present in the region as licensed stevedores tended to capture these concessions. For example, Maersk lines, of which APM Terminals is the terminal operating arm, had (and still has) a significant market share of the West Africa liner shipping trade, and Delmas Shipping, which had traditionally been the main

${ }^{27} \mathrm{Cf}$. Annex 3 for the detailed list of all terminal concessions in Nigeria. 
shipping line serving West Africa, was still at that time part of the Bolloré Group, until its sale to CMA-CGM in 2005. MSC, the third major shipping line serving the West Africa trades, was at the time of the first wave focusing its terminal operating activities on the main East-West trade lane ports.

57. The two dominant terminal operators in West Africa, APMT and BAL, are simultaneously cooperating and competing with each other for container terminal concessions in West Africa. There are numerous cases where the two firms operate terminal concessions in a joint venture partnership: Abidjan (both the current and the planned terminals) and Tema in West Africa, but also Douala and Pointe-Noire in Central Africa. In practice, over 80 percent of the current terminal capacity in West Africa is controlled by the two, as illustrated in Figure 9. The sub-regional influence of these firms is even greater if we consider non-CT facilities operated by them. For instance, BAL manages the RORO terminal in Dakar, dry ports in Burkina Faso and Chad, and the river port of Bangui (CAR), whereas APM Terminals is handling containers in Cotonou (Benin) but on public general cargo berths. The collaborative situation between APMT and $\mathrm{BAL}$ is also mirrored, to a large extent, in the multiple partnerships in other terminal concessions: China Shipping is a partner of Bolloré Africa Logistics in Lagos Tin Can Island, but of TIL in Lomé; TIL / MSC is a partner of APM Terminals in Badagry; and CMA-CGM is a partner of ICTSI in Lekki.

TABle 4: Container Terminal Concessions

\begin{tabular}{|c|c|c|c|c|c|c|}
\hline Port & Country & Operator & Participation & $\begin{array}{l}\text { Date of } \\
\text { signature }\end{array}$ & Type & Duration \\
\hline Abidjan & $\begin{array}{l}\text { Cote } \\
\text { d'Ivoire }\end{array}$ & SETV & $\begin{array}{l}\text { Bolloré Group then APMT } \\
\text { acquired } 40 \%\end{array}$ & October 2003 & $\begin{array}{l}\text { Competitive } \\
\text { then } \\
\text { negotiated }\end{array}$ & $\begin{array}{l}15 \text {, then } \\
25\end{array}$ \\
\hline Tema & Ghana & MPS & $\begin{array}{l}\text { Bolloré Group (35\%), APMT } \\
(35 \%), \text { GPHA }(30 \%)\end{array}$ & August 2004 & Negotiated & 20 \\
\hline Lagos & Nigeria & $\begin{array}{l}\text { Lagos Tin } \\
\text { Can Island } \\
\text { TICT }\end{array}$ & $\begin{array}{l}\text { Bolloré Group ( } 47.5 \%) \text {, Zim } \\
(47.5 \%) \text {, then } \mathrm{CMHI} \text { acquired } \\
\text { Zim's share and local partners }\end{array}$ & $\begin{array}{l}\text { September } \\
2005\end{array}$ & Competitive & $\begin{array}{l}15, \text { then } \\
20\end{array}$ \\
\hline San Pedro & $\begin{array}{l}\text { Cote } \\
\text { d'Ivoire }\end{array}$ & MSC & MSC & $\begin{array}{l}\text { September } \\
2008\end{array}$ & Competitive & 15 \\
\hline Lomé & Togo & LCT & MSC (50\%), CMHI (50\%) & December 2008 & Negotiated & 35 \\
\hline Cotonou & Benin & $\begin{array}{l}\text { Benin } \\
\text { Terminal }\end{array}$ & $\begin{array}{l}\text { Bolloré Group (75\%), SMTC } \\
\text { (Bolloré local subsidiary, 25\%) }\end{array}$ & $\begin{array}{l}\text { September } \\
2009\end{array}$ & Competitive & 25 \\
\hline Monrovia & Liberia & APMT & APMT & March 2010 & Competitive & 25 \\
\hline
\end{tabular}




\begin{tabular}{|c|c|c|c|c|c|c|}
\hline Lomé & Togo & $\begin{array}{l}\text { Togo } \\
\text { Terminal }\end{array}$ & Bolloré Group & June 2010 & Negotiated & 35 \\
\hline Freetown & $\begin{array}{l}\text { Sierra } \\
\text { Leone }\end{array}$ & BAL & Bolloré Group & November 2010 & Competitive & 25 \\
\hline Lekki & Nigeria & ICTSI & $\begin{array}{l}\text { ICTSI, then CMA-CGM acquired } \\
25 \%\end{array}$ & December 2012 & Negotiated & $?$ \\
\hline Abidjan & $\begin{array}{l}\text { Cote } \\
\text { d'Ivoire }\end{array}$ & $\mathrm{TC} 2$ & Bolloré Group 40\%, APMT 60\% & June 2013 & Competitive & 21 \\
\hline Dakar & Senegal & $\begin{array}{l}\text { Roro } \\
\text { terminal }\end{array}$ & Bolloré Group & November 2013 & Negotiated & 25 \\
\hline Badagry & Nigeria & APMT & APMT and MSC & July 2014 & Negotiated & $?$ \\
\hline Tema & Ghana & MPS & $\begin{array}{l}\text { Bolloré Group (35\%), APMT } \\
(35 \%), \text { GPHA }(30 \%)\end{array}$ & November 2014 & Negotiated & $?$ \\
\hline
\end{tabular}

FigURE 9: EVOlUtion OF THE MARKET SHARE OF TOCS IN WEST AfRICA (2004-2013)

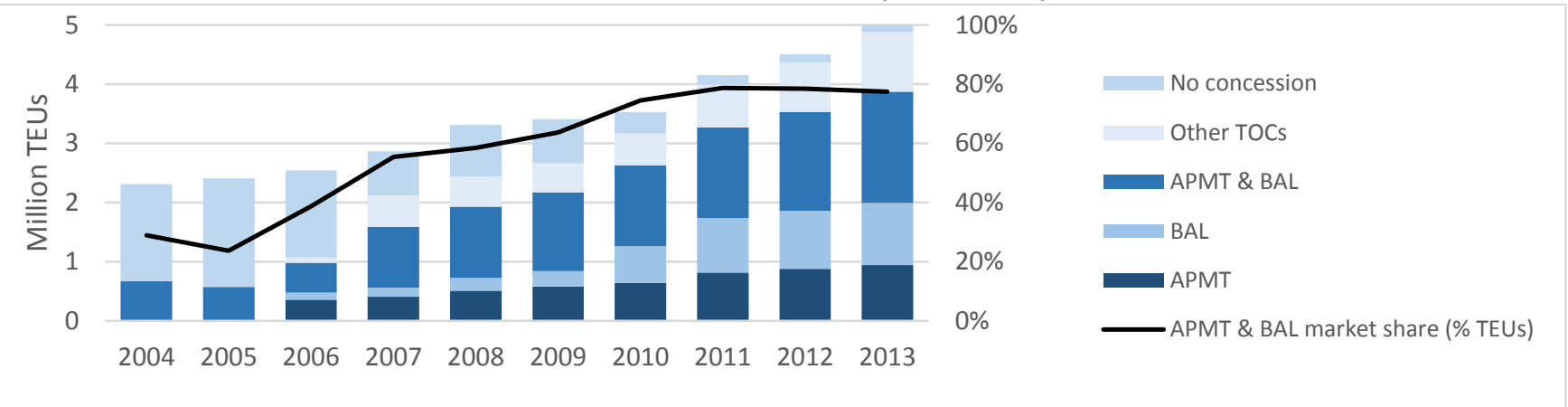

Source: authors' compilation based on port data

58. There are signs of change and some non-traditional players seem to be entering the West African market (Table 5 provides details on the terminal operators present in West Africa). When the first concessions in West Africa were announced, potential new participants were wary of a market which was largely unknown and where gauging the market risk was challenging to say the least. As the number of concessions in West Africa has increased and accumulated a more or less successful history, firms such as China Shipping and ICTSI are more willing to participate in the process. The entrance of new players does not necessarily guarantee a higher level of competition but does increase competition for the market and potentially results in better contracts and outcomes 
TABLE 5: AfRICA FOOTPRINT OF THE WESt AFRICA CONTAINER TERMINAL OPERATORS

\begin{tabular}{|c|c|c|}
\hline Terminal operator & In West Africa & Rest of Sub-Sahara Africa \\
\hline APM Terminals & $\begin{array}{l}\text { Monrovia (Liberia), Abidjan } \\
\text { (Cote d'Ivoire), Tema (Ghana), } \\
\text { Badagry (Nigeria), Lagos Apapa } \\
\text { (Nigeria), Onne (Nigeria) }\end{array}$ & $\begin{array}{l}\text { Douala (Cameroun), Pointe } \\
\text { Noire (Congo), Luanda (Angola), } \\
\text { Namibe (Angola) }\end{array}$ \\
\hline Bolloré Africa Logistics & $\begin{array}{l}\text { Freetown (Sierra Leone), } \\
\text { Conakry (Guinea), Abidjan (Cote } \\
\text { d'Ivoire), Tema (Ghana), Lomé } \\
\text { (Togo), Cotonou (Benin), Lagos } \\
\text { Tin Can Island }\end{array}$ & $\begin{array}{l}\text { Douala (Cameroun), Libreville } \\
\text { (Gabon), Pointe Noire (Congo), } \\
\text { Moroni (Comoros) }\end{array}$ \\
\hline ICTSI & Lekki (Nigeria) & $\begin{array}{l}\text { Matadi (DR Congo), Toamasina } \\
\text { (Madagascar) }\end{array}$ \\
\hline DP World ${ }^{28}$ & Dakar (Senegal) & $\begin{array}{l}\text { Maputo (Mozambique), Berbera } \\
\text { (Somalia) }\end{array}$ \\
\hline CMA-CGM & Lekki (Nigeria) & \\
\hline TIL / MSC & $\begin{array}{l}\text { Lomé (Togo), San Pedro (Cote } \\
\text { d'Ivoire), Badagry (Nigeria) }\end{array}$ & \\
\hline China Merchant Holding & $\begin{array}{l}\text { Lomé (Togo), Lagos Tin Can } \\
\text { Island (Nigeria) }\end{array}$ & Djibouti (Djibouti) \\
\hline
\end{tabular}

59. The second wave of sub-regional concessions differs from the first in that it involves large Greenfield terminal development. Terminal operating companies now manage almost all existing container facilities with the exception mentioned earlier of the Gambia and GuineaBissau $^{29}$. New concessions therefore involve the development of new terminals. The magnitude of the investments is a degree higher, with figures well above a billion dollars regularly quoted in the press. Investments of this magnitude require confidence about future volumes of activity and may explain why such development is being promoted by TOC's with clear linkages with shipping lines. Examples are MSC in Lomé and CMA CGM in Lekki, both of which are expected to be hub ports. Growth prospects are equally important: with the saturation of the Lagos port area, and what was then perceived as the sizable container trade forecast for Nigeria before the recent economic downturn, the prospects for new mega-ports around Lagos were looking bright.

\footnotetext{
${ }^{28}$ DP World used to managed the port of Doraleh in Djibouti until the Government cancelled the concession in July 2014 , and the case is still under arbitration

${ }^{29}$ The concession of the ports in Cape Verde was planned to be completed in February 2016, but the process is still pending.
} 


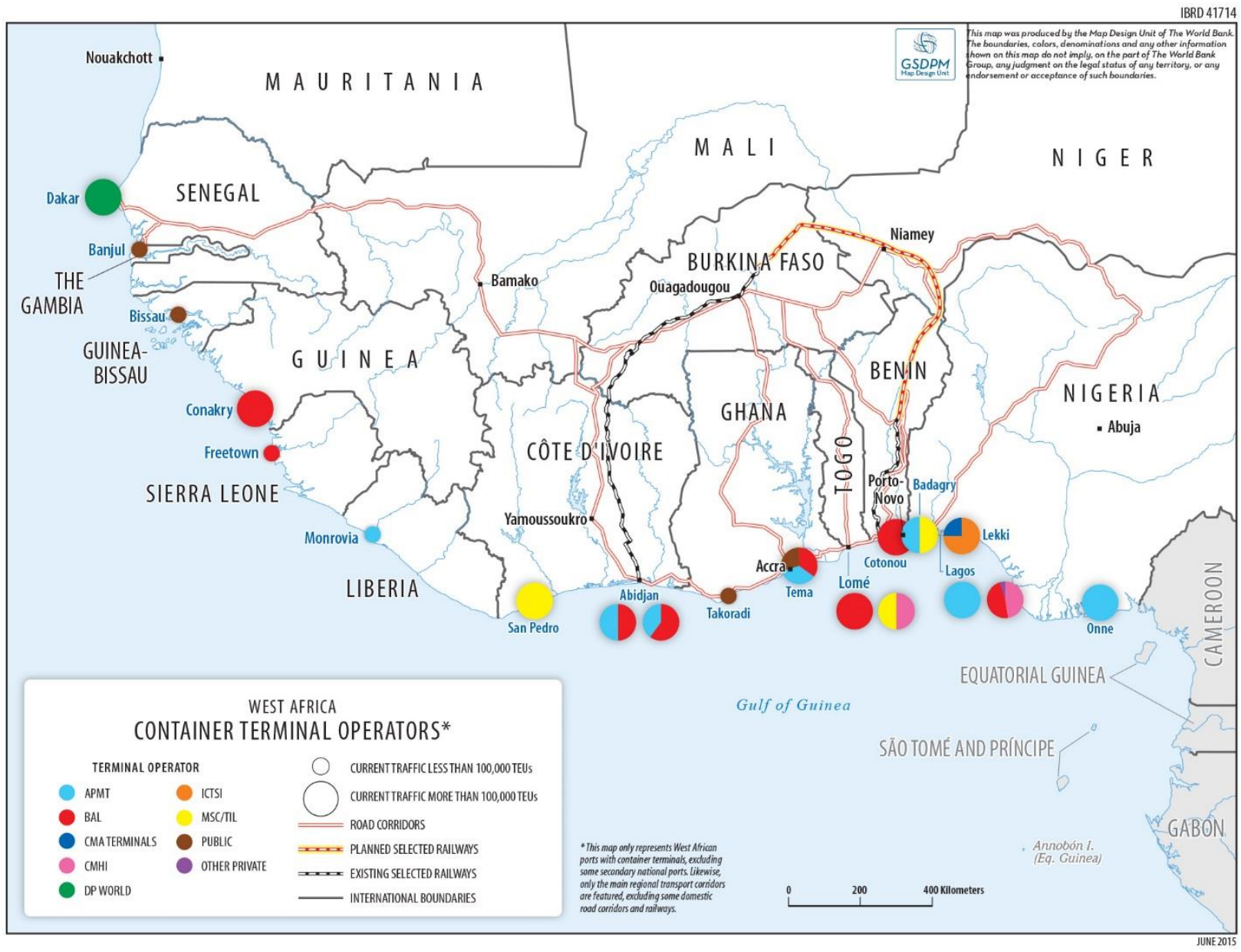

\section{The legal and regulatory framework for ports}

60. The presence of public-private partnership (PPP) legislation is an important signal of government readiness to engage with the private sector, as it provides a predictable legal framework within which businesses and citizens can act, plan and invest. PPP or concession laws may be enacted for a number of reasons, such as to give priority to a process of developing, procuring and reviewing PPP projects that will take priority over sector laws, or to establish a clear institutional framework for developing, procuring and implementing PPPs. PPP laws can also be used to close gaps in the laws of a host country where the modifications are embodied in sector-specific law, procurement or competition law for open and fair procurement processes, or included in a general concession or PPP law. Such changes are often found concurrently with greater financial and human resources being allocated to training and capacity building, which in turn support more PPP transactions. Despite these positive associations, legislation is not a necessary pre-condition for successful port concessions, as demonstrated by the cases of Liberia and Sierra Leone. 
61. Most West African countries, with the exception of Nigeria, lack comprehensive and specific PPP legislation to support private sector participation in infrastructure projects such as ports. The analysis of the policy and legal framework governing PPP in the countries studied presents a contrasting picture: less than half the countries have a PPP law on the books, and an equivalent number have no specific legislation. Among those who have made provisions for PPPs, the Ivory Coast has concession-related provisions in its Public Procurement Code while Sierra Leone approved a specific PPP law in 2010. With the Infrastructure Concession Regulatory Commission (ICRC) Act of 2005 and a number of policy papers and regulations since then, Nigeria has created the most advanced regulatory environment for infrastructure concessions at the national level albeit one that is still to deliver on its promise. Individual states have followed the federal example, with Lagos State the most advanced in this respect. The Parliaments of Benin and Ghana are currently in the process of reviewing specific legislation for private sector participation. On the policy front, Ghana has a National PPP Policy since 2011, while Guinea, Togo, Gambia and Liberia are completing diagnostics on their PPP frameworks, supported variously by PPIAF and the IFC (International Finance Cooperation).

\begin{tabular}{|lll|}
\hline \multicolumn{2}{|l|}{ TABLE 6: VARIATIONS OF PORT PPP LEGISLATIONS IN WEST AFRICA } \\
\hline $\begin{array}{l}\text { Specific PPP } \\
\text { legislation } \\
\text { implemented }\end{array}$ & $\begin{array}{l}\text { Specific PPP } \\
\text { legislation in process }\end{array}$ & $\begin{array}{l}\text { No specific PPP } \\
\text { legislation }\end{array}$ \\
\hline $\begin{array}{l}\text { Côte d'Ivoire } \\
\text { Nigeria }\end{array}$ & Benin & Gambia \\
Sénégal & Ghana & Guinea \\
Sierra Leone (2010) & & Liberia \\
\hline
\end{tabular}

Source: ECORYS, August 2015

62. By and large, national regulatory frameworks have evolved to facilitate a move toward the landlord port model and introduce private sector participation into cargo handling, but have paid scant attention to establishing suitable regulatory institutions. Ports sector organization is considerably influenced by the regulatory framework and is composed of numerous entities with different roles and overlapping responsibilities (Table 7). The ministry of transport or another government agency, such as a national or local port management body, typically undertakes the regulatory function. These institutions fulfill a variety of economic and technical regulatory functions, but none of these bodies offer truly independent regulation. Even Nigeria with its structured regulatory framework is still debating its plans for an independent regulator, which was part of its port reform package. This ad hoc approach to regulation undermines the objective of ensuring an efficient and competitive organization of port activities through technical, economic and financial standards (Grosdidier de Matons, 2012). 
TABle 7: NATIONAL MiNISTRIES AND AgENCIES IN CHARgE OF PORT REgULATION IN WeSt AfRiCA

\begin{tabular}{|ll|}
\hline Country & Ministry / Agency \\
\hline Cote d'Ivoire & Ministry of Maritime Economy, Ministry of Finance, Presidency \\
\hline Ghana & Ministry of Harbours and Railways \\
\hline Nigeria & $\begin{array}{l}\text { Ministry of Transport } \\
\text { Bureau of Public Enterprises } \\
\text { National Council of Privatisation } \\
\text { Infrastructure Concession Regulatory Commission }\end{array}$ \\
\hline Senegal & Ministry of Public Works, Equipment and Surface Transport \\
\hline Togo & Ministry of Transport \\
\hline Guinea & Presidency, Ministry of Transport \\
\hline Liberia & Ministry of Transportation \\
\hline Sierra Leone & Ministry of Transport and Aviation \\
\hline Gambia & Ministry of Works, Transport and Telecommunication \\
\hline
\end{tabular}

63. In the absence of comprehensive legislation and a designated regulatory body, the dayto-day activities of ports in most ECOWAS countries are regulated through national laws and international conventions which are implemented and monitored by the port authorities themselves. In most West African ports, it remains unclear as to where decision-making authority and accountability on issues relating to economic regulation, reform and governance really lies: the port authority, the line Ministry (ies), and/or the various public agencies involved in economic infrastructure and trade development. Port authorities find themselves de facto responsible for regulation but also challenged to effectively manage port operations when several layers of government agencies interfere in the concessioning and regulation process, and in wider port policy. For example, the regulation of tariffs is normally supported by the guidelines of the ministries in charge of trade and competition. In practice, however, there is considerable room for port authorities, which are closer to actual terminal and shipping operations and often have a much better knowledge of port finance and economics than their line ministry, to negotiate and set tariffs for some of the services offered by private operators.

64. There is an inherent conflict in the port authority assuming the functions of, and substituting for, an independent regulator. In most West African ports, harbor tariffs such as harbor, ship and goods dues fall under the general remit of the port authority, acting as a government entity. The port authority is thus able to control its own revenue stream; combined with the low levels of financial reporting to and monitoring by central government, this creates the conditions for the emergence of a powerful "state within the state" which sometimes escapes the authority of its line ministry. Additionally, the port authority may be more effective in enforcing compliance with contract provisions than in limiting abuses from monopoly power, ensuring a fair distribution of privatization gains, or promoting intra- or inter-port competition, as these could adversely affect its own revenue stream. Yet clarifying the roles of and 
responsibilities of government and its various entities is a challenge not only in West Africa but across continents, and has elicited varying responses depending on the local environment.

65. In West Africa, three port authorities are shareholders in the container terminal operating business. Participation ranges from 5\% for the Lomé Port Authority in the Togo Terminal (BAL owns $88.3 \%$ ) to $10 \%$ for the Dakar Port Authority in DP World Dakar, and 30\% for the Ghana Ports and Harbors Authority in MPS. The notion of a port authority being a shareholder in an operating company, even in a minority position, contradicts the landlord principle where the port authority should not be involved in any commercial operations. Furthermore, not only does it create an obvious conflict of interest but to maintain an appearance of level playing field the port authority should then be a shareholder at the same level in all future concessions in the area it manages. This latter quickly becomes untenable. The reason normally invoked for participating directly in commercial operations has to do with control of the concessionaire. A better way to achieve this is to have good, enforceable contracts, competent monitoring of performance and willingness to apply remedies when warranted.

\section{The concession process and governance issues}

66. Institutional and regulatory imperfections notwithstanding, the sub-region had completed 37 PPP transactions in the port sector by 2013. In the case of large-scale projects, given the high strategic and financial stakes, central administrations have tended to take control of the tendering process through a mix of official (line ministry, ministry of finance, PPP units, public procurement regulatory agencies, etc.) and unofficial (direct talks between bidders and highest levels of government) lines of communication. A relatively loose governance structure has thus been created where contradictory messages are sent to the market, exposing port authorities to protests and legal actions from disgruntled bidders. In countries where the practice of tendering large infrastructure projects is not standard yet, deals are generally struck with terminal operators at the presidential level (for example, in Benin, Togo and Guinea). Even where a competitive process was undertaken, the lack of prior experience in the design, negotiation and award of concessions in the infrastructure sector, and specifically in the port industry, has given a clear advantage to private negotiators. The exceptions are the countries such as Liberia, Sierra Leone and Benin who recruited support from international transaction advisors. The unequal capacities of the concession contenders and the conceding authorities are reflected in the uneven quality of tender packages and the nature of the negotiated agreements along various dimensions. As in other countries and regions, the administrative outcomes and substance of the concession contracts have also been shaped by the interaction of political and economic incentives.

67. Even for competitive bids, the concession process has been far from flawless, and the results often questioned or disputed. Port reforms are notoriously sensitive, and generate sometimes heated arguments before, during, and after the reform. Container terminal 
concessions are not different, and very often, press releases and statements from all parties reflect attempts to influence the process. Once the concession results are known, it is quite common for the losing bidders to go public and complain. The difficulty then is to sift between unfounded claims and more established facts. The cases detailed below were selected because facts had been reviewed by independent institutions.

68. Most of the complaints from bidders, all of which have been well publicized in the transport press and mainstream news, fall under two main categories: (i) competition issues, and (ii) corruption and fraud. For the first category, the selected example is the concession of the second container terminal in Abidjan, which was disputed on the basis of competition regulations both in Cote d'Ivoire, with the public procurement agency, and regionally, with the UEMOA Commission. For the second category, we discuss the concessions for Dakar and Conakry where the issue was not the legality of the process but rather accusations of corruption or worse.

69. In Cote d'Ivoire, the concession for the second container terminal of Abidjan was awarded to the same TOC which was already operating the existing terminal. This prompted complaints from the other bidders. After the Port Authority of Abidjan announced the results of the bid assessment in March 2013, declaring the consortium BAL and APMT the winner of the tender, the consortium led by CMA-CGM filed a complaint with the Public Procurement Authority of Cote d'Ivoire ('Autorité Nationale de Régulation des Marchés Publics' - ANRMP). The basis for the complaint was the alleged infringement of the competition regulation and disregard for the technical assessment of the offers. The complaint was dismissed by the ANRMP through a decision made in May 2013. CMA-CGM and the other bidders then turned to the Competition Commission of the West Africa Monetary and Economic Union (UEMOA) whose deliberations are only consultative.

70. In Senegal, after the presidential elections in 2012, the newly elected administration looked into the circumstances surrounding the award of the concession of the container terminal. The 'Inspection Générale de l'Etat' was appointed to conduct an enquiry which notably led to the arrest of the former Managing Director of the Port Authority. He was jailed from November 2013 to November 2014 under suspicion of corruption. The report of the IGE was released in October 2012 under the reference 91/2012, and the following section draws from the extensive quotes of that report in a USAID report on governance in Senegal ${ }^{30}$. DP World proposed to pay an entry ticket of 54 billion CFA Francs for the concession of the container terminal. This ticket was split in two with 30 billion CFA Francs in cash paid at the signing of the concession, and the remaining 24 billion CFA Francs paid through the ownership of $10 \%$ of the shares of DP World Dakar.. However, the IGE review established that all of DP World Dakar shares value was only 1 billion CFA Francs, thus the $10 \%$ awarded to the Port Authority of Dakar were worth only 100

${ }^{30}$ Quarterly / Annual performance report October 2012 - September 2013 available at http://pdf.usaid.gov/pdf docs/PA00KJMM.pdf 
million CFA Francs. To settle the dispute, DP World agreed in June 2013 to pay in cash (?) to the Government of Senegal 24.6 billion CFA Francs, equivalent to $\$ 48$ million $^{31}$, to settle this valuation matter.

71. In Guinea, the concession of the container terminal attributed to GETMA, part of the group NECOTRANS, in 2008 was cancelled in 2011 and attributed to BAL, with GETMA filing court cases to fight the cancellation and obtain compensation. In Conakry, container handling was performed by licensed stevedores, subsidiaries of the NECOTRANS and BAL groups. The international tender for the concession of the Conakry container terminal was launched in May 2008, and awarded to GETMA, with a concession contract signed in September 2008 for a duration of 25 years. However, in March 2011, the newly elected government cancelled the concession, and awarded the terminal to BAL, which was ranked second in the 2008 tender. NECOTRANS filed cases against BAL with the Tribunal of Commerce of Nanterre (France) and against the Government of Guinea with the International Centre for the Settlement of Investment Disputes, case ARB/11/2932 (ICSID) seeking compensation of $€ 100$ million from BAL, accusing the group of having conspired for the cancellation of the concession since its signature in 2008. The Tribunal of Commerce dismissed the accusation due to lack of evidence, only awarding a compensation of $€ 2.1$ million for the investment in the terminal made by NECOTRANS prior to the cancellation of the concession.

72. Private sector participation in ports can take a number of forms: management contracts, partial divestiture to strategic equity partnerships, joint ventures, full divestiture, and concessions of various kinds. Management contracts are generally unattractive to terminal operating companies because of the inability to control factors that influence performance, like staff retention and employment conditions. Strategic equity partnerships are also unattractive to terminal operating companies in the absence of the ability to make investment and operational decisions considered necessary to achieve desired levels of performance. Joint ventures, however, hold considerable attraction as they exploit complementary resources and skills. Concessions (lease contracts or agreements) imply a degree of transfer of responsibility and therefore risk to the private sector. In the case of build-operate-transfer (BOT) concessions, responsibility for building and operating infrastructure is transferred to the private sector, while overall control and ultimate ownership of port infrastructure remain in public hands.

73. Concession contracts for container terminals may involve existing public assets or may require the development of new assets. In the first case the private operator manages publicly owned assets and makes additional investments in them, in exchange for the right to use them

\footnotetext{
31 The payment is recorded in the Revised Budget for the Government of Senegal, available at http://www.finances.gouv.sn/webmef/LFI/LFR 2013 2.pdf

32 Visit

https://icsid.worldbank.org/ICSID/FrontServlet?requestType=CasesRH\&actionVal=showDoc\&docld=DC2912 Fr\&ca seld $=$ C1900
} 
for a specified period of time. Ownership of the public assets remains with the public sector, and authorities have a continuing claim on port assets and revenues; privately-funded fixed assets are usually (but not always) taken into public ownership immediately after construction, while privately-funded mobile assets such as mechanical equipment usually (but not always) remain in private ownership. This is reflected in the 'transfer-back' arrangements at the end of the contract period, when the right to use the assets (now a mixture of public and privately provided) reverts to the public sector, which may then re-assign them to another operator. Various arrangements exist for compensating the private operator for the residual value of any investment made during its period of tenure. For fixed assets, "no compensation" transfers are probably still the most common. Mobile assets paid for by the private operator, in contrast, can usually be withdrawn or sold to the public sector, reflecting assumptions about ownership which are either explicit or implicit in the contract.

74. Most of the PPPs in West Africa are for existing assets and follow the lease-contract model, with Lagos (both Apapa and Tincan) being a typical case. A lease is a rental contract in which the port leases an asset (infrastructure, superstructure, or both), or the right to use it, for an agreed period of time in return for a bulk payment or a series of installments. There are two main types of lease arrangements: lease contracts and leasehold agreements. Lease contracts, which often have a built-in renewal clause, apply when an operator enters into a long-term lease, often 20 to 25 years, on the port land and becomes also responsible for superstructure and equipment. This seems to be the case for APMT Apapa, Tincan Island's TICT and PCHS, Abidjan's Vridi Terminal ${ }^{33}$, Tema's MPS Container Terminal, Cotonou Container Terminal, Dakar Container Terminal (DCT1), San Pedro's Container Terminal, Lomé's SE2M Container Terminal, and Conakry's Container Terminal. Most of those lease contracts have development requirements, often of an obligatory or event-triggered nature, requiring the operator to invest in port infrastructure, superstructure, or both. Leasehold agreements are simple rental agreements with only land or warehouse facilities being leased. Those have been widely used in bulk concessions in West Africa (e.g. Lagos, Monrovia, San Pedro, etc.), but are rarely used for container port concessions.

75. The Build-Operate-Transfer (BOT) model or any of its sub-sets (DBFM, RBOT, etc.) have been less common thus far but are likely to grow rapidly as the stock of existing port assets depletes. In this model, the private investor buys the right to build new port assets and have exclusive use of them for a fixed period of time before transferring them to the public sector. This model has been increasing in popularity in the ports sector as the stock of public assets suitable for private management has dwindled, and was most recently used in West Africa in Lomé's new container terminal and Dakar's Port du Futur. On the other hand, both Freetown and Monrovia seem to have applied a mix between the BOT model and the lease management model.

${ }^{33}$ Although the original concession was for 15 years. The concession was extended with the revision of the handling tariffs in 2013. 
76. Attracting very large investments from the private sector in port infrastructure and equipment does not seem to be an issue for most West African ports. Terminal operators often exceed minimum required investment amounts. As a corollary, there is no example in West Africa so far of a concessionaire's failure to comply with a concession's investment clauses. Obligatory investments, clearly specified, with an agreed time schedule, seem to be the norm in West Africa. Such agreements are most commonly seen in competitively tendered concession projects in countries which struggle with governance challenges, since pre-specifying the investment schedule increases the transparency of the bid evaluation process. It also makes the investment program legally enforceable. Obligatory investment programs are included in concessions where investments are urgently required, and/or there is a single technical solution available. In West African ports, such investment requirements are often captured in a development plan annexed to the concession agreement with pre-specified completion dates which, if unmet, can lead to the forfeiting of performance guarantees, the payment of liquidated damages, and even ultimately to the termination of the concession agreement.

77. Good practice suggests that investment requirements should to the largest extent possible be linked to capacity utilization and operational performance. Only when there is an obvious need, reconstruction or hazard to operate, should they be time bound. Demanding a concessionaire to sign-off on a pre-determined, time bound investment schedule in other circumstances carries at least three risks: (i) that investments are way ahead of time if demand does not follow forecasts (the cost of this will one way or another be charged back to the conceding authority), (ii) that investments are made despite sub-optimal productivity of existing assets which removes much of the incentive to maximize $\backslash$ utilization of existing infrastructure, and (iii) that the concessionaire prefers to litigate than comply, arguing for instance that an unexpected economic depression made all forecasts irrelevant. The best path would be to include triggers in the concession contract, such as reaching 80 percent of optimal capacity in two years in a row, or reaching maximum average acceptable waiting times six months in a row, to launch investment operations.

78. The duration of concession contracts in SSA ranges between $\mathbf{1 5}$ to $\mathbf{3 5}$ years, with the majority of the contracts between 20 to 25 years. In general, the duration of a concession contract is expected to vary with the expected value of fixed investments, the breakeven point and the return required by the private operators to participate. This suggests that brownfield concessions should be shorter than Greenfield ones. Port authorities ${ }^{34}$ prefer relatively short concessions for several reasons, but mainly because the willingness to pay for a concession rises only marginally with duration, particularly in politically and economically fragile countries.

\footnotetext{
${ }^{34}$ Pallis, A.A. , Notteboom, T. and De Langen P.W. Concession Agreements and market entry in the Container Terminal Industry (2010). Maritime Economics and Logistics, vol. 10, no. 3, pp. 209-228.

Essoh, Nome P. Cote d'ivoire Commodities Export and Shipping: Challenges for Port Traffic and Regional market Size. American Jornal of Industrial and business management, 2014, 4, 234-245.
} 
Shorter contracts, assuming they do not reduce private sector interest, are therefore better for maximizing the revenue of the port authority while reducing barriers to entry by offering more frequent opportunities to competitors.

79. These contracts show little correlation between the duration of the concession and the expected level of investment since private sector's investment is guided by the attainment of standard financial bankability ratios which depend, for the most part, on the forward balance/assessment of the project's revenues vs costs (including debt). In Togo, both concessions (Togo Terminal and LCT) have the same duration, whereas LCT (Lome Container Terminal) is Greenfield that relies on a minimum revenue guarantee provided by its shipper/port owner and Togo Terminal is a brownfield where the terminal operator has to take on market/demand risks. In Abidjan, the concession for the second terminal, a Greenfield development, is shorter than the revised concession duration for the first terminal in part because, like in Togo, its financial bankability is linked to differences in private sector perceived market/demand risks. The concession terms for the remaining Greenfield developments (extension of Tema, Badagry and Lekki) are not yet set, but are likely to be at the higher end of the range in terms of total payments to be made to conceding authorities.

80. Experience shows that obligatory investment programs lasting more than five years are rapidly overtaken by technological and market changes, and unless renegotiated can lead to unnecessary investments and excessive costs. Worldwide obligatory investment plans have therefore been largely replaced by indicative investment programs that can be modified by mutual agreement. This creates a less confrontational atmosphere between the concession partners, encourages innovation, and ensures that the majority of investments are commercially sound. In some occasions the development plan is phased or event-triggered so as to reflect the anticipated traffic demand. The first phase is then usually compulsory, while the following phases remain subject to agreement between the parties. However, in none of the contracts reviewed was the level and nature of the investments left purely at the discretion of the concessionaire, and port authorities seem to expect firm commitments from the private parties in that regard. This may be why investment commitments in West Africa have generally been realized.

81. Unbundling activities and contracting on a terminal rather than whole-port basis is expected to encourage efficiency through specialization and increased competition. Intra-port competition in turn can help ensure that private operators' behavior remains compatible with the public interest. Many of the benefits from concessions stem not from private presence per se, but from increased competitive pressures, while limited or absent competition can lead to the creation of rents at the expense of the public interest. Yet there is only one country, Nigeria, that has attempted to increase competition through unbundling. Even where there is sufficient traffic to permit more than one terminal to operate, governments have refrained from imposing restrictions on incumbent concessionaires. Thus in Abidjan and Tema there were no limitations placed on who could participate in the new or expanded concessions, allowing the potential 
emergence of a private monopoly. Dakar seems to be following a similar path with its new project of the "Port du Futur".

82. About half the contracts reviewed include provisions for exclusive rights to handle a specific type of cargo or vessel within the port or over a restricted geographic area, further limiting competition and perhaps undermining the drive towards efficiency. More generally, the provision of monopoly rights over a specified port service was a feature of early port PPPs, when the contracting modalities and confidence in the concession process were still developing. Nowadays, the requirements of small, marginally viable projects can be secured through refinements in clauses of the contract and without resort to exclusive rights over specific types of cargos or vessels. Still, such incentives may have been necessary where the risk valuation of private companies is high and the concessionaire may not enter the market without specific arrangements to assure profitability.

83. Common user clauses are found in all contracts, reflecting the sub-regions preoccupation with the tendering ports' gateway status and their strategic and economic importance to the country. These clauses impose on the concessionaire the requirement to allow access to any shipping line and service all vessels calling at the port. For similar reasons, all contracts reflect a concern for continuity of service -14 consecutive days or 60 non-consecutive days of interruption of services are the commonly accepted thresholds for termination in most contracts. While service continuity is easily monitored, the practical application of common user arrangements (in priority berthing and terminal discriminatory practices) has not been given much thought. Monitoring common user agreements can most effectively be done by setting up formal feedback mechanisms allowing users who believe they have been discriminated against to voice their claims. These claims and the results of their review by the concessioning authority should then be made public; for instance on the authority's website.

84. In general, performance parameters can be useful to measure the success of an operator in managing the terminal and help align the interests of both parties. In practice, detailed metrics require extensive control by the port authority and effective monitoring instruments. The performance indicators may relate to, inter alia: traffic - number of ship calls or containers or tons of cargo passing through the terminal, per time unit (day, week, month and year); crane productivity - number of container movements by crane per time unit; ship productivity - the output achieved per ship working hour; quay productivity - number of container moves per unit of time per meter of quay length; terminal productivity - number of containers handled per square meter or hectare of terminal area per time unit. When required levels are exceeded, a positive financial incentive could be given to the operator because extra traffic and throughput results in extra revenue for the port authority. Conversely, the port authority should be entitled to apply penalties when the minimum targets are not achieved. 
85. Nearly all the contracts reviewed include operational performance obligations expressed in terms of (i) hours of operation, (ii) crane productivity (ranging from 9 to 25 moves per hour), (iii) handling equipment availability (greater than 90 percent), (iv) average truck turnaround time (for instance, less than 45 minutes for a single container transaction), and (v) throughput capacity. In all except one case, failure to achieve the targets does not result in a financial penalty, although the concessionaire may consider prolonged underperformance as a default event. There are, however, several issues related to these indicators: the targets are set too low, the ability and capacity of the authorities to monitor achievements is questionable at best, and tools to leverage these improvements into better performance are missing. Due to these deficiencies, and because the concessionaires' revenues are linked to throughput handled at the terminal creating an intrinsic incentive to improve performance, the indicators, as defined, are not very meaningful.

86. In the majority of the agreements a minimum throughput guarantee is required and expressed as a volume commitment, where the volume goals are calibrated to the size, attractiveness of the terminal and its growth prospects. In the case of new terminal assets, the volumes are expected to double in six to eight years, indicating the rather optimistic outlook on the growth potential of the West African container market. It is only here that failure to meet the agreed traffic targets has a financial consequence for the concessionaire and we see penalties in the form of compensation to the port authority. These throughput or volume guarantees are misleading as they are in reality revenue guarantees and should be expressed accordingly. An independent operator has no way of controlling or guaranteeing traffic, and even operators linked with shipping lines do not have a say on line policies. Such guarantees then translate into an operator commitment to pay a minimum, floor amount to the conceding authority which is on top of the fixed lease value, typically calculated as a royalty per TEU. So the volume guarantee boils down to a floor royalty payment. It would be better for the conceding authority to express it as such and avoid any possible litigation related to lower traffic volumes due to extraordinary circumstances.

87. Despite a mélange of stated objectives, concession contracts in West Africa seem to be awarded essentially on the value of the financial package offered by the bidder. The invitations to tender for a terminal concession nearly always dwell on the government's desire to implement sector reforms and modernize the country's gateway port. In nearly all cases, the conceding authority seeks success through contractually agreed improvements in operational performance and the technical requirements to deliver improved performance are sometimes part of the qualifications for interested bidders. An associated motive for inviting the private sector is to develop the local port as a regional "hub" - throughput targets and agreed investments in capacity enhancements are expected to make the port more attractive to international clients and help fulfill these aspirations. Concerns for the quality of the water and air in the port's vicinity, and targets for the employment and training of locals are also occasionally mentioned in the contract documents. Irrespective of the specific combination of criteria stipulated in the bid documents, 
nearly all concessions reviewed have been awarded purely on the value of the financial package offered by the bidders. The main concern of the authorities appears to be maximization of the dedicated revenue stream from the concession contract to help meet financial gaps in port and government budgets.

88. While financial terms for concession contracts are not public documents, information available publicly supports the observation that maximizing Government revenues is the primary criteria for contract award. In Guinea, four TOCs submitted proposals for the Conakry container terminal: BAL, APMT, GETMA and TCB (Ternimal de contenidors de Barcelona)/ Afrimarine. On the technical criteria, the ranking was GETMA, BAL, TCB / Afrimarine and APMT, in that order. On the financial criteria, the ranking was GETMA, APMT, BAL and TCB Afrimarine. GETMA offered the highest entry ticket at $€ 15$ million, while APMT, ranked next, proposed $€ 10$ million $^{35}$. In Abidjan ${ }^{36}$, the BAL APMT consortium proposed an entry ticket of $€ 120$ million, and a fixed annual fee of $€ 22$ million, higher than, for instance, the MSC-led consortium with respectively $€ 80$ million and $€ 8$ million (the financial terms for the CMA-CGM led consortium were not reported in the decision of the Public Procurement Authority, but reported in the shipping press ${ }^{37}$ at respectively $€ 76$ million and $€ 7.5$ million). In Lagos, the concession of the Apapa container terminal granted to APMT was valued at $\$ 1.06$ billion, far higher than the second bid, at \$202 million, by ICTSI. In all cases, the award went to the highest bidder. The governments' emphasis on the financial terms rather than tariffs to end users or operational parameters feeds into the continuance of high tariffs which considering that a very large proportion of the container traffic is captive, shippers have little choice but to pay.

89. The relative proportion of fixed fees and royalty payments varies by contract and makes allowances for the level of perceived risks. Most of the contracts reviewed include payments composed of (i) an entry fee, ranging from US\$1 million to US\$150 million; (ii) a relatively high fixed fee, between US\$1 million to US\$25 million, payable monthly, quarterly, semi-annually or annually to compensate the conceding authority for the use of the concession area, with the charge bearing no relationship to the actual throughput; (iii) a variable, comparatively modest royalty, ranging from US\$16 to US\$44 per TEU; and (iv) revenue sharing based on an agreed percentage of the income generated by the terminal (ranging from $19 \%$ to 23\%). Both fixed and variable fees are typically contractually increased with increases in a pre-specified inflation index. In most cases, the initial fee rates are included as bidding criteria in the financial offer, though in some instances one of the fees is spelled out in the bid documents. Some connection is observed

\footnotetext{
${ }^{35} \mathrm{http}$ ://www.guineeconakry.info/article/detail/affaire-terminal-conteneurs-mais-quelle-est-la-version-officielle/

${ }^{36} \mathrm{http}$ ://www.anrmp.ci/contentieux-77111/decisions-26968/file/138-decision-n-009-2013-anrmp-crs-du-08-mai2013-sur-la-denonciation-faite-par-le-groupement-international-container-terminal-services-inc-ictsi-cma-cgmtterminal-link-movis-necotrans-pour-irregularites-commises-dans-la-procedure-de-passation-de-l-appel-doff?start $=80$

${ }^{37}$ http://portfinanceinternational.com/categories/emerging-economies/item/904-bollor\%C3\%A9-and-apmt-signconcession-agreement-for-abidjan\%E2\%80\%99s-second-container-terminal
} 
between the type of terminal and the fee structure: in larger, established container terminals, the emphasis is on maximizing revenues with entry tickets and fixed fees comprising the bulk of the payments. In smaller terminals, in more challenging environments, with higher risks for the operator, variable fees and revenue sharing arrangements dominate.

90. Governments have failed to use concession agreements to reduce the high levels of tariffs in most West African ports, partly because of their expectations on concession fees. At the same time, many of the West African concession agreements include maximum tariff rates for each type of service (indexed for inflation). Arrangements for regulating tariffs vary among countries, with some based on rates specified in concession agreements, some relying on proposals from representatives of private firms, and others mandated by the port authority (or proposed by the operator subject to approval by the port authority). For the most part, tariff rates have remained close to the maximum level allowed, although for some cargoes discounts are provided to attract traffic. In general, port authorities have made little effort to ensure that tariffs are competitive, for example by undertaking periodic reviews of tariff rates in light of global experience. One exception is the case of the second container terminal in Abidjan where tariff reductions were specifically included among the assessment criteria. The winning proposal by BAL and APMT included a commitment to reduce the maximum tariffs by $25 \%$ (essentially reversing the tariff increase allowed by the regulator for the first terminal operated by the same consortium) against the $22 \%$ proposed by the TOC ranked second. Measuring the margins for tariffs reductions would require information on the accounts of the TOC at terminal level that is not available, in order to take into account the balance between operating costs, concession fees and investment versus revenue. However, the decision to reduce tariffs in Abidjan by $20 \%$ taken in 2013 shows that this margin does exist.

91. The characteristics of the port sector and the specificities of the West African context demand adequate public intervention to maximize benefits and minimize risks. The impact of inadequate experience and capacity on the transaction process, the quality of the concession contracts, the level of competitive pressure and finally the allocation of benefits between the concessionaire and other stakeholders has been amply documented. Countries likely undertake one or two port concessions every decade or so, and with the exception of a few countries (Nigeria, Cote d'Ivoire and Ghana) the majority are unlikely to have more than one concessionaire in the port sector (not including the dedicated, private ports). A modest but promising endeavor could be to promote the establishment of lean regulatory outfits, ideally bi-national, on the main regional corridors. These are already functioning to some extent for railway operations on bicountry networks, and it would be possible to extend their mandate to freight operations on a given corridor, including port terminals, and give them power to regulate tariffs. When several of these corridor regulatory bureaus are in place, RECs could collect their data and start monitoring the corridor network on a regional basis. This would not directly address the lack of transparency during the concession award process but is likely to start limiting the prospect of 
abuse. This is an area where IFls could take the lead and provide a forum for discussion, agreement and support for implementation of the agreed outcome.

92. Increasing transparency in the contractual concessioning process is likely to be the most critical starting point to improving outcomes. The growth of container traffic volume projected for the coming decades will make TOCs potentially good partners in adapting supply to demand for port services. In this context, it is critical to strengthen immediately public negotiation and regulation capacity, as well as improve the governance of the port sector, the legal framework and the competition policies, in order to secure economic benefits for West African countries. Steps are required to ensure that future concessions focus on performance and guarantee a fair distribution of benefits, and that active concessions are adequately regulated to maximize economic benefits for the countries.

93. Greater mobilization of the demand side and more systematic public information disclosure on performance and costs would go a long way in rebalancing the relationship between TOCs and African shippers. Since there is an inherent asymmetry of power and negotiating capacity between the ultimate clients of the ports and the TOCs, systematically disclosing operational and cost information to the general public provides an opportunity to bring together the virtual constituency of regional port users. Generalizing the publication of tariffs and key performance indicators is the first step to improve transparency and facilitate policymaking. Then one could think of ways to formalize customer feedback loops by including specific provisions to this effect in concession agreements, complemented by mandatory disclosure provisions. The data collected through these systematic feedback processes at the local port level could then form the basis for a region-wide database that would allow meaningful comparisons between facilities and also hopefully nurture some emulation between them. The Regional Economic Communities would at some point become the logical place to host and manage this concessions operational database.

94. Given the regional dynamics of ports in West Africa, there is also a good case for more cooperation between West African countries on port reform, competition and regulation. Strengthening the capacity and mandate of regional institutions such as the ECOWAS Commission on these issues would complement regulatory efforts at the country level and provide a forum to analyze regional issues related to inter-port competition and private sector participation in port management.

BOX 3: THE CONCESSION CONTRACT FOR THE ABIDJAN SECOND CONTAINER TERMINAL

The concession of the second container terminal of Abidjan is an interesting example of public disclosure, as it is the only public contract for the West Africa concessions: it has been published in the Cote d'Ivoire official gazette (JO No9 dated February 27, 2014).

The contract and its annexes provide some examples of good practices that could be replicated in second generation concession contracts: 
- The respective obligations of the port authority and the concessionaire are clearly spelt out. The port authority commits to the infrastructure developments required for the second container terminal (enlarging and deepening the access channel and turning basin, building the quay wall and reclaiming the yard area) in order to enable access for a 110,000 tons vessel ( 350 meters long, 43 meters wide, 16 meters draft, 65 meters above sea level). The concessionaire commits to finishing the yard area and the quay front for the STS rail, connecting the terminal to the railway network and investing in handling equipment;

- The investment program is defined in two tranches, one fixed corresponding to the minimum equipment of the terminal at its opening (6 over-panamax STS and 13 RTGs) and defines conditions (based on throughput) for additional handling equipment (STS and supporting yard equipment)

- The performance indicators and the targets are defined: crane productivity, equipment availability, and truck turnaround time.

- Customer feedback mechanism and control by the port authority on how the complaints are handled by the concessionaire

IT data exchange with community systems 


\section{Have the Container Terminal Concessions in West Africa Delivered?}

95. The main driver of the concession of container terminals in West Africa was the need to address the capacity constraint resulting from poor performance and outdated terminal characteristics. Few West African ports were equipped with gantry cranes, and handling in most ports relied on ship's gear. Low productivity levels lead to congestion, and penalties for shippers by shipping lines in the form of congestion surcharges. Port authorities did not have the resources to modernize their container facilities, and concessions of container berths to terminal operators were widely seen as the silver bullet to the capacity crisis. The arrival of TOCs in the West Africa port landscape has consequences for both the short term, with a focus on capacity management (or how to increase the output measured in TEUs with constrained input, defined as terminal physical characteristics), and for the long term, when the traffic growth will require developing new container terminal capacity (increased output through expansion of the input). Chapter 4 is focusing on the short-term aspects, the impact of port terminal concessions on capacity, port efficiency, and prices, while the next Chapter focuses on the long term adequacy between container traffic and capacity.

\section{A. Impact of container terminal concessions on capacity}

96. The annual capacity of a container terminal is a function of its physical characteristics. These were first formalized by UNCTAD in its 1985 Port Development Handbook as the minimum throughput of each main terminal function, as illustrated in Figure 10: berth transfer between ship and quay, transfer between quay and yard, yard storage, and gate transfer. Over time, the formula was refined to take into account possible variations in terminal characteristics, so there may be a wide variance in the reported capacity of the container terminal, depending on method and hypothesis used in the calculation.

97. Poor performances exacerbate capacity constraints. Low productivity at berth lengthens the time needed at berth to handle a given volume of containers on board of a ship, and beyond a certain level of berth occupancy, waiting delays escalate. Shipping lines are very sensitive to the time spent in ports, whether outside the port waiting for an available berth, or at berth, delayed by low productivity. From a shipping line perspective, ample capacity reserves are good, but from a port authority or TOC perspective, that means over-investing or over-anticipating the growth of the demand. The challenge is therefore to strike the correct balance between performance, investment and anticipation of growth. 
FIGURE 10: FACTORS IN THE CALCULATION OF THE CONTAINER TERMINAL CAPACITY

\begin{tabular}{|c|c|c|c|}
\hline Ship to quay & Transfer to yard & Yard storage & Gate transfer \\
\hline $\begin{array}{l}\text {-Volume and } \\
\text { characteristics of the call } \\
\text { (empties vs. full, } \\
\text { transhipment, inbound } \\
\text { vs, outbound, etc.) } \\
\text { - Quay handling equipment }\end{array}$ & $\begin{array}{l}\text { - Reach stackers or } \\
\text { tractors+trailers } \\
\text {-Distance quay - yard area }\end{array}$ & $\begin{array}{l}\text {-Stacking configuration } \\
\text { and yard handling } \\
\text { equipment } \\
\text { - Characteristics of the } \\
\text { traffic (empties vs. full, } \\
\text { transhipment, inbound } \\
\text { vs, outbound, etc.) } \\
\text {-Dwell time }\end{array}$ & $\begin{array}{l}\text {-Appointment scheme for } \\
\text { trucks } \\
\text { - Gate lanes } \\
\text { - Rail / road split }\end{array}$ \\
\hline
\end{tabular}

B. The transformation of the container terminals in West Africa

98. Before the first wave of container terminal concessions, only a handful of West Africa ports were equipped with STS cranes for containers, and most shipping lines had to deploy geared vessels on the West Africa trades. Handling productivity with ship's gear is low, generally below 10 moves per crane per hour. Moreover, geared vessels are of limited capacity, a maximum of 2,500 TEUs, with therefore a higher unit cost per TEU than the vessels of 4,000 TEU or more that have become common on West Africa trades. Yard handling equipment was also outdated, as most operations relied on reach stackers and therefore low density yards, which in turn limited the capacity of the terminals.

99. With the transfer of container activities to terminal operators, very often the first investment was to modernize the handling equipment. For instance, in Lagos Apapa, where congestion was acute, the container terminal had only 2 STS cranes and 2 mobile harbor cranes (MHCs). APM Terminal added 4 STS in 2008, 3 MHCs in 2011, and another 3 MHCs in 2012. For the yard equipment, APM Terminals had 8 rubber-tyred gantry (RTG) cranes in operation by 2009. Five more were added in 2011 (one was retired), and 4 more were ordered early in 2015. Once those last four delivered, the total operational fleet will be 12 RTGs (with some older equipment retired). In the Abidjan Container Terminal, the handling equipment taken over by the TOC at the start of the concession included three STS and one crane, and the yard was operated with reach stackers. A fourth STS was added in 2009, followed by two more in 2011, and two again were ordered in 2016. In addition to the initial crane, one was added in 2012, and a third one in 2014. The yard operation was converted to RTG, with an initial batch of 8 at the end of 2007, following by 8 more in 2009, and four in 2015. In Tema, MPS acquired from GPHA three STS and 4 RTG that were delivered in 2005. Two mobile cranes were acquired in 2010, followed by a third one in 2012. In 2013, 9 RTG and 2 STS were added. Those are not isolated case: similar phased investments in handling equipment were made in all West Africa ports after TOC took over the management of the terminals. 
100. In numerous cases, quay length and yard area were also expanded: in Conakry, BAL extended the quay wall by 340 meters, more than doubling its length, and added 6 hectares of yard; in Lomé, BAL extended the quay length in its terminal by 450 meters; in Abidjan, the terminal operator strengthened the existing quay to enable it to accommodate STS cranes; and in Lagos Apapa terminal, APMT dredged all four berths to a draft of 13.5 meters.

101. In Tema and Cotonou, the concession provided the opportunity to create a dedicated container terminal. In Cotonou, as detailed earlier, the creation of the terminal preceded the concession, but in Tema, the terminal operator reconfigured the multipurpose berths into a container terminal. Existing sheds in Tema were demolished to make room for a container yard, and the quays were strengthened. The terminal entered into partial operation in 2007, and full operation in 2008.

102. These investments boosted handling productivity. APMT reported an increase from an average of 6 moves per hour prior to the concession, when ship's gear was predominantly used, to 24 moves per hours at the end of 2012, reducing congestion and pre-berthing delays. BAL reported an increase at its Conakry terminal from 19 container movements per hour in 2011 to 35 in 2014. Data published by MPS in Tema show that crane productivity averaged 20 moves per hour in 2012, and ship productivity fluctuated between 35 and 45 moves per hours. However, it is difficult to compare productivity levels between ports, because frequently the reported performance indicators differ (for instance, some ports report crane productivity while ship productivity is used by other). Moreover, call conditions (such as total call volume to handle, location of the containers on board, etc.) affect productivity and conditions differ from one port to another, and even within a port, from one line to another. However, available data confirms that productivity increased shortly after the TOC took over the operations.

FIGURE 11: SHIP PRODUCTIVITY IN ABIDJAN AND TEMA (SOURCE: BAL)

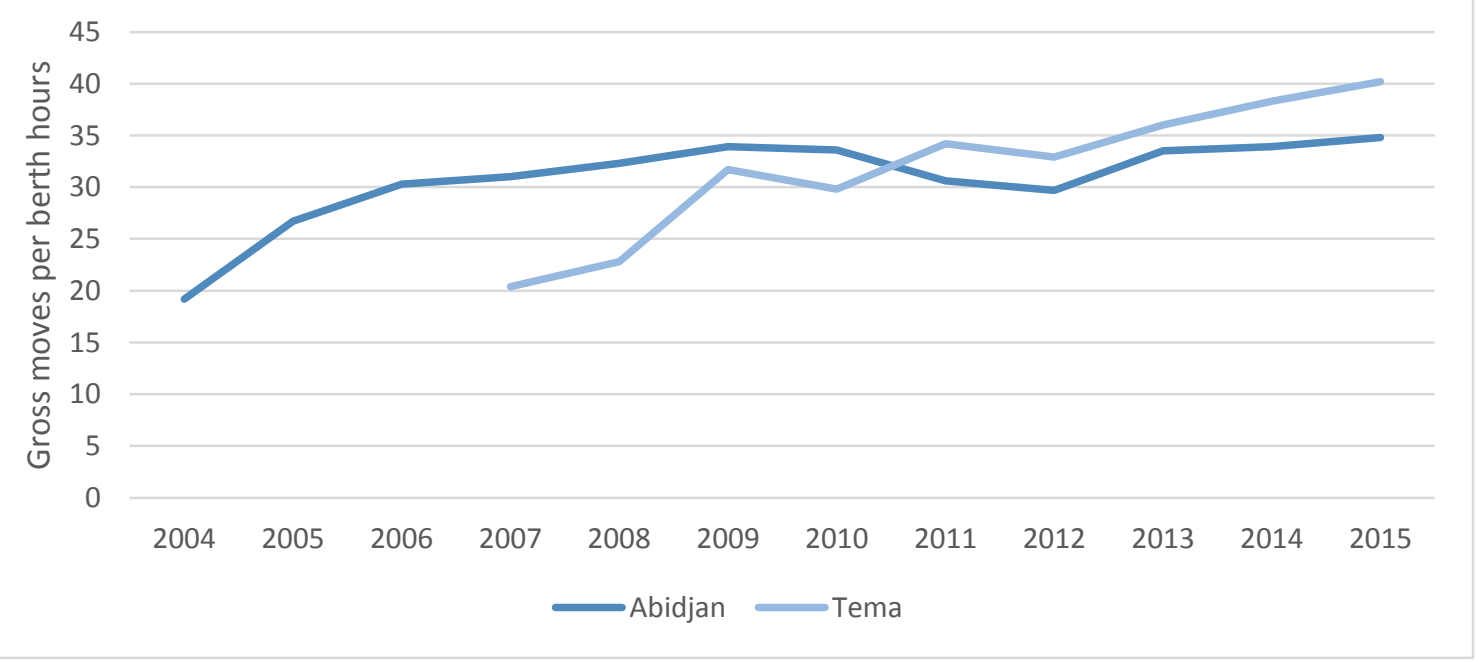


103. Terminal operators have made investments to modernize West African container terminals, and after only a few years of operation many are well advanced in fulfilling the commitments made at the time of the signature of the concession. For instance, APMT in Monrovia committed to a US\$120 million upgrade and modernization program for the port. So far, the firm has completed a US\$50 million, 600 meter quay wall reconstruction, and a further US\$34.5 million has been invested in rehabilitating and upgrading the container yard, offices, terminal gates and IT, after five years in 25 years concession. In Lagos Apapa, APMT has invested US\$220 million in a comprehensive terminal upgrade, and recently initiated a further US\$135 million investment to expand capacity to 1.2 million TEUs. After investing US\$37 million in the rehabilitation of the port in Freetown, compared to an initial commitment of US\$20 million for the first three years, BAL announced the development of a 750,000 TEU terminal (eight times the existing capacity) in October 2015, which will require an investment of US\$120 million. In Cotonou, after investing in handling equipment, BAL has announced a $€ 50$ million extension of the yard area (partly gained on the sea) and connection to the railways ${ }^{38}$. The total will represent over $80 \%$ of the committed investment for the entire duration of the concession. Since the concession in 2004, investment in the Abidjan terminal has been as follows: (i) initial program (defined in the concession contract) for an amount of 27 billion FCFA, for the period 2004-08, (ii) second program, for the period 2009-14 for an amount of 30 billion FCFA, and (iii) the current program, for the period 2015-19, for an amount of 39 billion FCFA. In total, up to end 2016, total invested amounted to $€ 160$ million, beyond the contractual commitment of $€ 147$ million.

TABLE 8: INVESTMENT IN SELECTED TERMINAL CONCESSIONS IN WEST AFRICA PORTS

\begin{tabular}{|c|c|c|c|}
\hline \multirow[t]{2}{*}{ Port } & \multicolumn{3}{|c|}{ Investments } \\
\hline & $\begin{array}{c}\text { Committed over total duration of the } \\
\text { concession }\end{array}$ & $\begin{array}{l}\text { Realized as of } 2015 \\
\text { (\%) }\end{array}$ & $\begin{array}{l}\text { Planned beyond } \\
2015\end{array}$ \\
\hline Freetown & $\$ 20 \mathrm{M}$ in phase 1 & $\$ 37$ M (100\%) & $\$ 120 \mathrm{M}$ \\
\hline Monrovia & \$120M & $\$ 85$ M (70\%) & \\
\hline $\begin{array}{l}\text { Cotonou - Bénin } \\
\text { Terminal }\end{array}$ & $\$ 256 \mathrm{M}$ & $\$ 150 \mathrm{M}(60 \%)$ & $\$ 60 M$ \\
\hline Lagos - Apapa & & $\$ 220 M$ & $\$ 135 \mathrm{M}$ \\
\hline Abidjan & \$181 M & \$176 M (97\%) & $\$ 44 \mathrm{M}$ \\
\hline
\end{tabular}

\section{Reaching the limits of capacity management?}

104. Investment in modern quay and yard handling equipment by the TOCs enabled terminal capacity to keep up with traffic growth, but some terminals are reaching their limits. In Tema for instance, MPS handled 50\% more TEUs in 2015 than at the beginning of its operations in 2008, and two-thirds more in Abidjan in 2015 compared to 2004. Accommodating such growth through handling equipment only has its limits, and there is a point when new infrastructure becomes

\footnotetext{
${ }^{38} \mathrm{BAL}$ has, in a separate development, won the concession for the Benin Niger railway, and is currently extending the railway line from its current end in Parakou (Benin) to Niamey
} 
necessary. It is therefore not surprising that both ports launched major infrastructure developments to further increase container capacity.

105. Despite improvements introduced by TOCs in terms of better handling equipment and terminal management techniques, performance - expressed in moves per hour - in West Africa remains low compared to international benchmarks. The most significant efficiency gain which helped unlock 'frozen' capacity, was achieved through additional or more productive quay handling equipment, and densification of the $\operatorname{yard}^{39}$. To a large extent (as discussed above), the initial investments of the terminal operators focused on rationalizing and upgrading handling equipment, with investment in Ship-to-Shore cranes and yard gantries, rather than expanding infrastructure, in particular, new quays and larger yard areas. Annex 4 presents an overview of the terminal characteristics and equipment as of October 2015 , compiled from various sources (terminal operator websites, press release and articles in specialized shipping press). Although TOCs, port authorities and shipping lines agree that performance has improved, these pale in comparison to international figures: for instance, switching from ships gear to STS cranes boosted the number of container moves per hours from below 10 to above 20, still behind the 30 and plus moves per hours that is considered the norm elsewhere. A more comprehensive development of port performance indicators features in the next section while elements of benchmarking are detailed in Box 4.

\section{Box 4: Benchmarking Container Terminal and Port Productivity}

From a shipping line perspective, time in port is critical. With only one port of call in West Africa Lomé - MSC launched its Asia West Africa weekly service with 10 vessels only, i.e. a loop of 70 days, while in comparison, most of the competing services operated by CMA CGM and Maersk require 12 or 13 vessels, for loops of 84 and 91 days respectively to be able to serve up to 5 or 6 ports in West Africa. The number of moves per port hours is therefore the critical performance indicator that shipping lines take into consideration, as time savings enable expanding the geographic coverage of ports while keeping a loop which is a multiple of seven.

Performances are influenced by the size of vessels and volume of the call: high volume routes allow for higher performances, putting Africa at a disadvantage in international comparisons. On the major East-West trade lanes, large container vessels over 12,000 TEUs are the norm, and their size enable TOCs to use much more gantry cranes along their side than for the smaller vessels $-4,500$ TEUs - that are deployed in West Africa. Comparing performances is therefore not in favor of West Africa ports. The Journal of Commerce published its Port Productivity White Paper in July 2014 and is maintaining a database on port productivity. 2013 regional average reached 90 moves per hour in Asia, hovered just above 60 moves per hour for America and almost reached 70 moves per hour for Europe. The regional difference also translate differences in vessel size and call volumes.

TABLE 9: REGIONAL AVERAGE FOR SHIP PRODUCTIVITY ACCORDING TO VESSEL SIZE

\begin{tabular}{|l|l|l|l|}
\hline Region & Less than 2,500 TEUs & $7,500-10,000$ TEUs & 10,000 TEUs and more \\
\hline
\end{tabular}

\footnotetext{
${ }^{39}$ Switching from reach-stacker to RTG operation allows for a more compact design of the container stacking areas, and higher stacking of containers on the same ground slot.
} 


\begin{tabular}{|l|l|l|l|}
\hline America & Below 40 & Above 80 & \\
\hline Asia - Pacific & 50 & Above 100 & Above 120 \\
\hline Europe and Mid-East & Below 40 & Above 90 & \\
\hline
\end{tabular}

Source: JOC White Paper on Port Productivity, July 2014

FIGURE 12: BENCHMARKING AFRICA PORTS 2014 PERFORMANCES

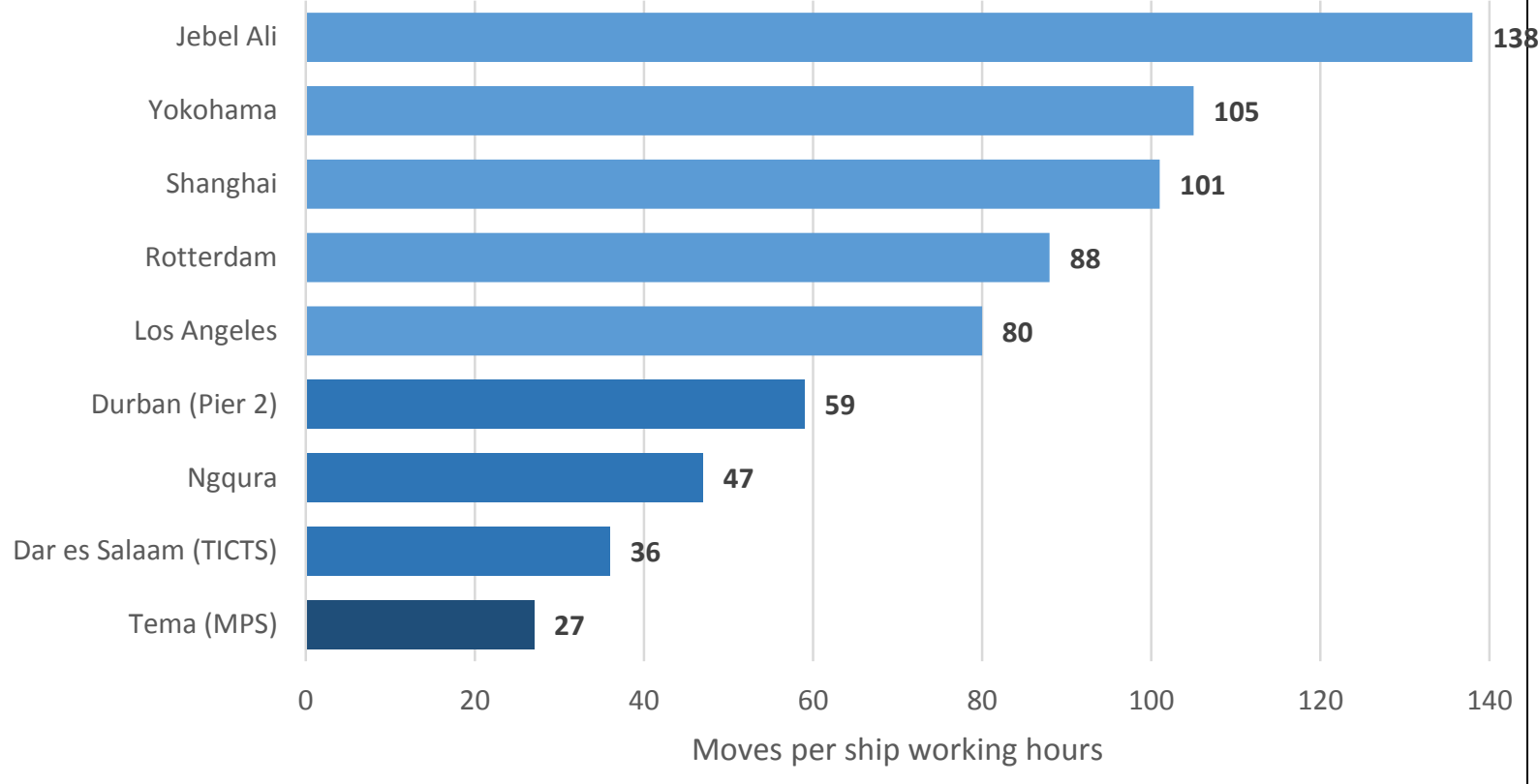

Source: Port Regulator of South Africa, Benchmarking report 2015, using JOC Productivity database quoted by UNCTAD Review of Maritime Transport 2015

The huge differences in port productivity are amplified by differences in vessels size. Crane productivity is typically an average of 20 moves per crane per hours in West Africa, 25 to 30 for South Africa, and 35 to 40 for Asia. Comparing crane productivity with ship productivity shows that in Tema for instance, a ship uses on average one crane and a half, whereas in Durban, that ratio is just above two, is close to three for Los Angeles, and four to five for the top performing terminals in Asia (for instance 180 moves per ship hour for the Yokohama APM Terminal), highlighting the role and importance of vessels size and call volumes.

However, performances should align with international benchmark with the arrival of larger vessels on the West Africa trades. Maersk first with its 4,500 TEUs wafmax vessels introduced in June 2011, then MSC with its 6,000 TEUs and more on its Asia West Africa service vastly increased the average size of container ships on the West Africa trades. Larger vessels handling larger volumes of containers per call should enable TOC to show performances comparable to other regions, now that trade related differences decrease. Monitoring the performances of the TOCs in the coming years will help determine if the performance gap was actually due to the characteristics of the calls or not.

106. However, it is important to note that the comparatively low performances preventing TOC to fully unlock capacity reserves are largely due to circumstances beyond their control. In the function determining theoretical capacity, the two main binding constraints are usually quay 
transfer capacity and yard capacity (cf. Figure 10). Quay capacity is primarily a function of berth productivity, for which crane productivity is an important input, but not necessarily the dominant one. Berth and port productivity ${ }^{40}$ measure the total number of movements during a ship's call, and crane productivity measures the number of movements per crane. Both the ship and the call characteristics have a significant influence on the level of performance (larger ships with larger call volumes can achieve higher productivity), and the nature of the liner services in West Africa changed so much over the last decade that comparisons over time would shed little light on the impact of the TOCs. For instance, it is common to find references to over 35 moves per crane hour as the standard benchmark for crane productivity, but this performance is usually achieved for large call volumes, which is still rarely the case in West Africa. Berth productivity depends on the number of cranes that can operate a ship, and it is obvious that a 2,500 TEU ship cannot accommodate the same number of cranes along its side as a 8,000+ TEU ship. Yard capacity is essentially a function of dwell time: the maximum number of containers that each available yard slot can handle each year equals the total number of days per year divided by the average dwell time. With dwell time routinely longer than half a month, when ideally it should be well below a week, improvements in port procedure have the potential to unfreeze yard capacity, but this depends largely from border management agencies, clearing and forwarding agents and shippers $^{41}$, and not from TOC.

\section{Efficiency gains from terminal concessions}

107. An analysis of $\mathbf{1 3}$ container terminals of the West Africa range between Dakar and Lagos, for a period of 10 years from 2004 to 2013, shows that improvements in efficiency are found where the TOC took over from public service ports in Tema and Lagos Apapa (see annex 2). By contrast, no improvement in efficiency is found with the transfer of responsibility from licensed stevedoring companies to TOCs. The change was therefore gradual for the tool ports, with an upgrade of the cargo handling equipment, but more abrupt, with new business models, for the two public service ports. The situation of Lomé is atypical, because licensed private stevedores before the concession already performed cargo handling, but efficiency shows a significant improvement with the start of the upgrade of the container terminal infrastructure.

108. Major modifications of the container terminal characteristics also affect the efficiency scores. In Dakar and Abidjan, reconfigurations of the container terminals seem to be the reason for changes in efficiency, once the effect of throughput is eliminated: an expansion of the Dakar container terminal completed in 2011 modified the inputs, but throughput continued to grow at

\footnotetext{
${ }^{40}$ Port productivity considers the total time in port, including waiting time before berthing, while berth productivity measures only performance at berth.

${ }^{41}$ See notably Raballand, Gaël, Salim Refas, Monica Beuran and Gözde Isik. 2012. Why Does Cargo Spend Weeks in Sub-Saharan African Ports? Lessons from Six Countries. Washington DC: The World Bank
} 
its steady pace, negating the improvement in efficiency that marked the first two years (2008/09) under the concession. In Abidjan, similar modifications of the inputs with the program of modernization of the handling equipment launched in $2008^{42}$, combined with erratic movements in the throughput, resulted in erratic efficiency scores.

109. However, all terminals under concession show better efficiency scores than could be expected from their volume of activity, hinting at a positive impact of TOC involvement through the upgrade of the container facilities. The nature of the input-output function used to measure efficiency is such that a high efficiency score translates into a better match between the volumes being handled and the infrastructure and superstructure of the container terminal. The fact that the main container terminal concessions improve their efficiency over time implies that the TOCs are better than public authorities at fine tuning the terminal characteristics to adjust to the growing demand, which would in turn imply that investments in new facilities and new handling equipment are more closely triggered by evolutions of the traffic.

110. The Malmquist Productivity Index (MPI), can determine whether terminal efficiency gains recorded in the West African ports are solely attributable to traffic growth and only marginally to TOC management of the terminal facilities. The MPI can be decomposed into three components: (i) the pure technical efficiency change effect (PEC), (ii) the scale efficiency change effect (SEC) and (iii) the technological change effect (TC). The results for the set of West Africa container terminals already analyzed through the DEA analysis are illustrated in Figure 13:

- Total factor productivity (TFP) change shows an upward trend in the past decade, with two regressions in 2005-2006 and 2009-2010. Those results are consistent with those of the DEA analysis;

- Scale efficiency change (SEC) follows a similar upward trend, and experiences the biggest jump from 2010 to 2013, reflecting new terminal capacity;

- Technological change (TC) has its biggest increase between 2006 and 2008, which is the period in which most terminals were transferred to TOCs; and

- Pure efficiency change (PEC) improved starting from 2007-08, which is also the time when most terminal concessions took place.

42 Delivery of the fourth STS crane in 2009, RTGs in 2011, followed by two new STS cranes in 2013 
FIGURE 13: MPI ANALYSIS OF TERMINAL EFFICIENCY

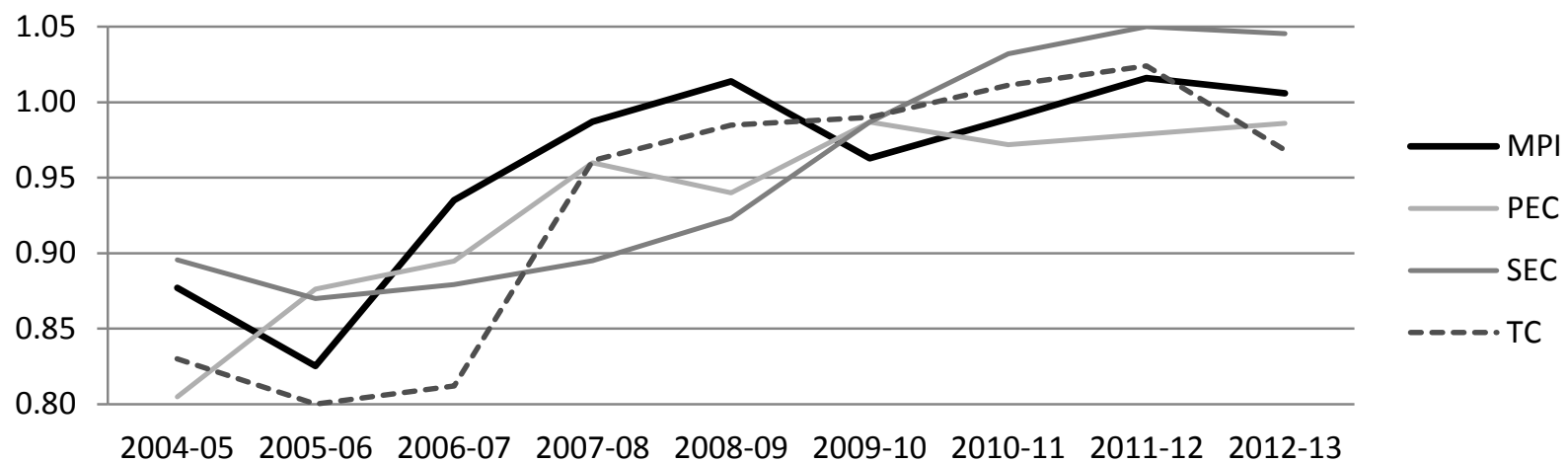

111. The MPI analysis confirms the findings of the DEA analysis, i.e. the main sources of efficiency gains are firstly volume, enabling economies of scale, and secondly technological progress, reflecting the upgrade of the terminal facilities. The important conclusion that can be drawn is that where productivity gains were made, the sources of those gains seem to derive from either scale efficiency (due to increases in supply capacity) and/or technological progress (due to upgrades or purchase of new equipment, streamline of working processes, reduction in procedural bottlenecks).

\section{Impact of Concessions on container terminal prices and costs}

112. Cargo handling tariffs in West Africa ports are normally approved and published by the port authorities, but they are not widely disseminated. Information on the West Africa ports is not always available or updated: several West Africa port authorities do not have a website, even those who do have one do not update its content regularly, and tariff information is almost never published beyond the immediate port community (the only notable exception is the port of Lomé). Data on tariffs, in some cases in time series, have been collected through a wide range of sources for the port of Dakar (through the association of port stevedoring companies), Abidjan (through the Cote d'Ivoire maritime federation), Tema (through shipping agents), Lomé (through the port website), and Cotonou (through the Abidjan Lagos Corridor Authority).

113. Cargo handling tariffs in West Africa ports are revised infrequently. Tariffs tend to remain unchanged for long periods of time: in Dakar, the tariff applicable in 2002 was only revised in 2015; in Abidjan, the tariff remained unchanged between 2002 and 2010; in Lomé, the tariff for container handling was adopted in 2008 and is still valid; and in Cotonou, the tariff adopted in 2010 was modified in 2015. There are however exceptions; for instance, Ghana has been updating port tariffs annually over the past few years. When tariffs are modified after a long period of stability, calculating the increase is not simple, because often the structure of the tariffs has changed. For example, a comparison between the tariffs in Dakar in 2002 and 2015 is not possible due to the change in the structure, from mixed tariffs mostly based on tonnage to rates per TEUs. When updates of the tariffs are more frequent, it becomes possible to calculate 
percentages of increases as the tariff structure remains unchanged. For instance, in Cotonou, the 2010 tariff was increased by a flat 26 percent in 2015 for all categories of rates (Table 10), although, in dollars, the increase was lower at $7 \%$ due to the change of parity between Euro and Dollar. In Ghana, during the same period, the stevedoring charges were increased by $32 \%$, after a long period of quasi-stability.

FIGURE 14: EVOLUTION OF STEVEDORING (SHIP HANDLING ONLY) RATES IN TEMA

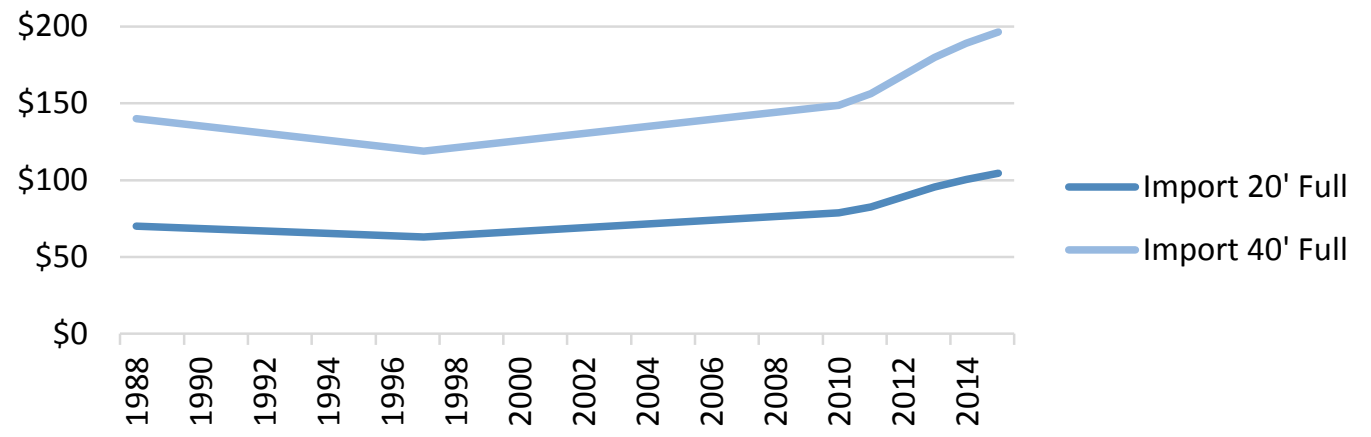

TABLE 10: COMPARISON 2010 - 2015 OF THE CONTAINER HANDLING TARIFFS IN COTONOU

\begin{tabular}{|lcccc|}
\hline & \multicolumn{2}{c}{ September 2010} & \multicolumn{2}{c}{ May 2015} \\
\hline Container handling in FCFA & $20^{\prime}$ & $40^{\prime}$ & $20^{\prime}$ & \multicolumn{1}{c|}{$40^{\prime}$} \\
\hline Import container delivered full on truck & 82,500 & 136,400 & 103,950 & 171,864 \\
\hline Import container positioned for stripping & 93,750 & 155,000 & 118,125 & 195,300 \\
\hline Export container & 41,684 & 73,560 & 52,522 & 92,686 \\
\hline
\end{tabular}

114. Tariff revisions are sometimes opposed by the shippers, with varying degrees of success. The latest increase in Ghana, around 4 percent for stevedoring but up to 20 percent for other container movements, was supposed to be effective in July 2015, but protests by shippers postponed its effectiveness to October 2015, although the level ultimately remained unchanged. In Abidjan, operators complained about the high prices for port stevedoring, and the Government included provisions for the reduction of tariffs in the amendment to the concession agreement signed in 2012, leading in 2013 to a reversal of the 18 percent increase in 2010.

115. Tariff revisions do not always coincide with the timing of the container terminal concession, and the terminal operator inherits the tariff structure and level. In the case of Dakar, tariffs were revised eight years after the concession was signed (concession in 2007 and tariff revision in 2015) and six years later in the case of Abidjan (concession in 2004 and revision in 2010). In Lomé, the tariff applied by SE2M and GETMA ${ }^{43}$ in 2008 is still applicable, after the concessions of LCT and Togo Terminal respectively at the end of 2008 (but the terminal only

\footnotetext{
${ }^{43}$ In Togo, container handling was opened to private stevedoring companies in 2002, with the licensing of SE2M, followed by the licensing of a second operator, GETMA, in 2008
} 
opened at the end of 2014) and 2010. In Cotonou, the concession was signed in 2009, before the update of the tariff, but the terminal opened only early 2013, while the next revision of the port tariffs took only place in 2015. In almost no case were operational efficiency improvements reflected in a decrease in tariffs to shippers.

116. The disconnect between costs and prices in container handling enables most TOCs to maintain special tariffs for special types of traffic put in place by the public authorities. Tariff differentiation serves several purposes: a strategic purpose (for instance, export containers are charged less than import containers to promote exports, which is also the case for free zone containers in Lomé), a social purpose (certain commodities, such as rice or pharmaceuticals, benefit from lower rates), and a marketing purpose (transit traffic with the landlocked countries is given discounted rates). In the four ports ${ }^{44}$ illustrated in Figure 15, Abidjan and Lomé have the widest range of special rates, with respectively 5 and 6 different rates, while Cotonou only discriminates between import and export containers (the CFA rates have been converted into UD dollars at the prevailing rate of 590 F CFA per US\$). The level of concession rates varies from one port to another, as illustrated in Figure 16. Abidjan has the most nuanced pricing, with concession rates for transit and special commodities, followed by Lomé. Cotonou and Dakar, on the other hand, focus their tariff concession rates respectively on export and special commodities. Although the data in Dakar seems to indicate that transit does not benefit from special rates, in practice it does because cotton benefits from the special export rate (even coming from Mali) and this is the main, if not only, transit export commodity.

Figure 15: CONTAINER HANDLING IN SELECTED WeSt AfRicA PORTS, IN US\$

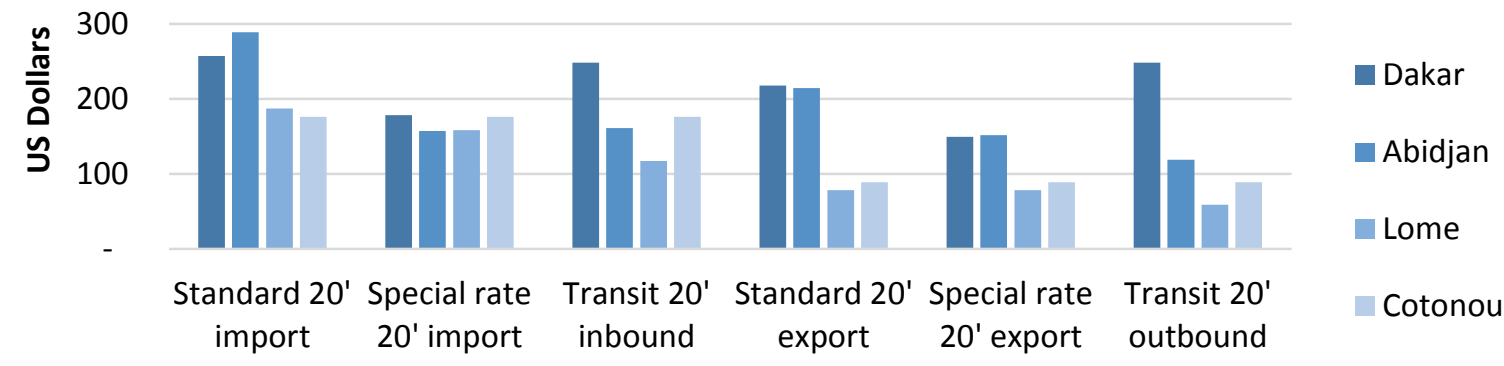

\footnotetext{
${ }^{44}$ When different rates apply for stripped or closed containers, the rate for closed container has been selected
} 
FigURE 16: RATIO FOR CONTAINER HANDLING CONCESSIONAL RATES IN SELECTED WEST AFRICA PORTS

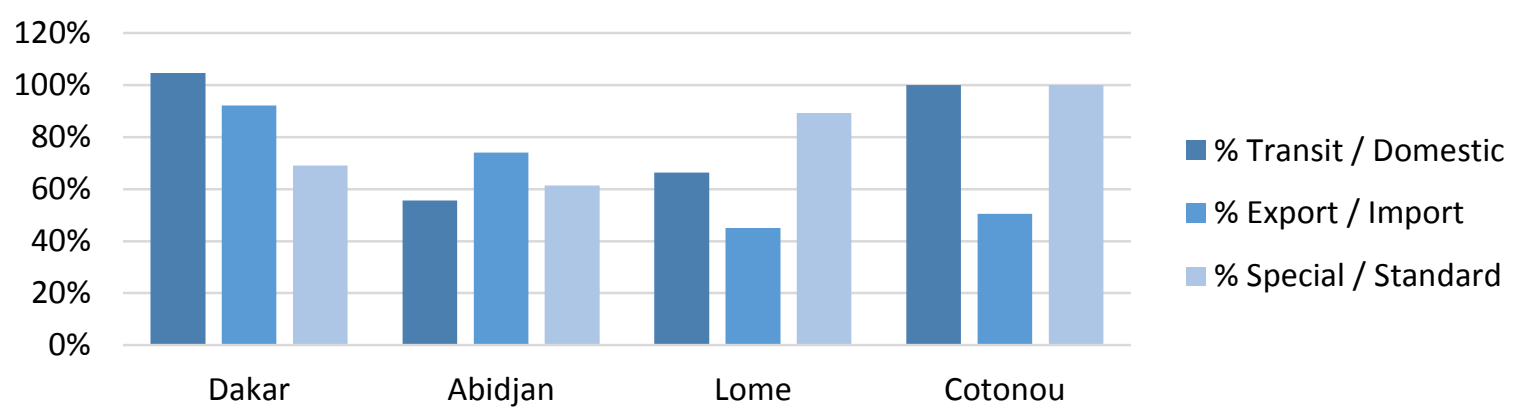

117. Tariffs levels and throughput volumes determine cash flows available to finance investments in the terminal. TOCs earn revenues from shipping lines and shippers by providing varied services: for cargo handling and storage paid by the shipping lines (movements required to access the containers, the portion of cargo handling borne by the shipping line for loaded container, the handling of empty containers, and empty container storage), and for cargo handling paid by the shippers (between ship and yard, between yard and vehicle or stripping area, and storage beyond grace period for loaded containers). A fuller picture, which includes expenditure items for capital investment and operations of TOCs is illustrated in the table below.

TABLE 11: EXPENDITURE AND REVENUE ITEMS FOR TOCS

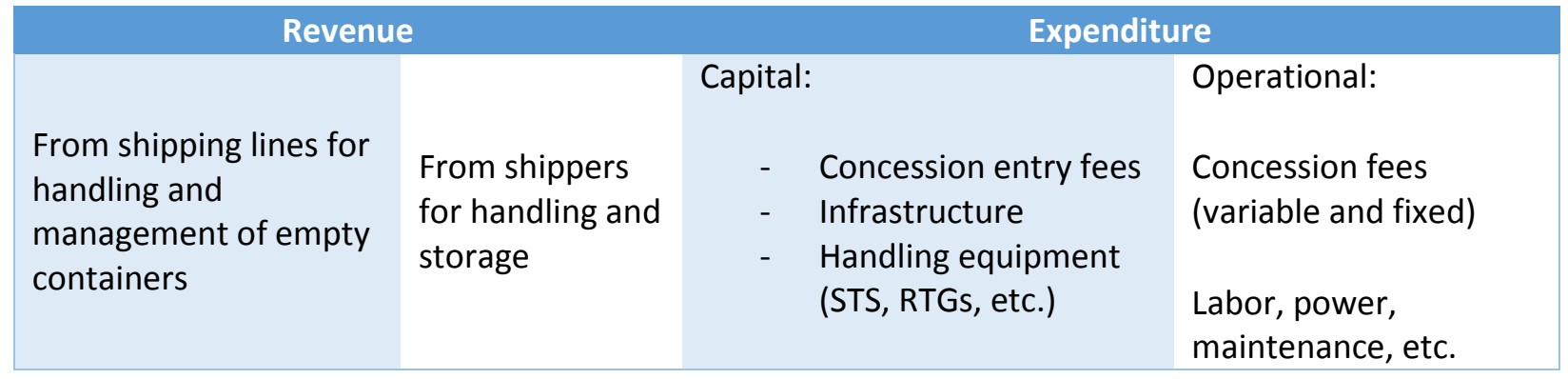

118. A very basic estimate of the total revenue of a typical TOC can be obtained by multiplying throughput by tariffs. For the Abidjan container terminal ${ }^{45}$ attempts to reconstruct the revenue derived from the container throughput, assuming no income from storage beyond the grace period. The reference year for the throughput and the tariffs is 2013, after the decrease of $20 \%$ accepted by the TOC on cargo handling tariffs. Tariffs in FCFA and Euros have been converted into dollars at the rate applicable then, i.e. $\$ 1=$ FCFA 500 and $€ 1=\$ 1.15$. Handling tariffs differ according to nature of the cargo, weight of the container, and destination (transit or domestic); here the standard rate for a 20 foot container has been applied (simulations using actual tariffs when consignment level data was available show that using the standard rate actually provides a lower bracket estimate of the revenue).

\footnotetext{
${ }^{45}$ Abidjan is the only port for which published tariffs detail some of the items borne by the shipping lines: the ship handling for loaded and empty containers.
} 
TABLE 12: TENTATIVE ESTIMATE OF THE REVENUE FOR ABIDJAN TERMINAL FOR THE YEAR 2013 (USD)

\begin{tabular}{|c|c|c|c|c|c|c|}
\hline & TEUs 2013 & $\begin{array}{c}\text { Paid by Ship } \\
\text { per TEU }\end{array}$ & $\begin{array}{c}\text { Paid by } \\
\text { shipper per } \\
\text { TEU }\end{array}$ & $\begin{array}{c}\text { Total paid by } \\
\text { Ship }\end{array}$ & $\begin{array}{l}\text { Total paid by } \\
\text { Shipper }\end{array}$ & Total revenue \\
\hline \multicolumn{7}{|l|}{ Inbound } \\
\hline Empty & 100,600 & $\$ 30$ & $\$ 0$ & $\$ 3,018,000$ & $\$ 0$ & $\$ 3,018,000$ \\
\hline Full & 169,800 & $\$ 60$ & $\$ 341$ & $\$ 10,190,000$ & $\$ 57,877,000$ & $\$ 68,067,000$ \\
\hline Transshipment & 57,700 & $\$ 42$ & $\$ 183$ & $\$ 2,423,000$ & $\$ 10,533,000$ & $\$ 12,956,000$ \\
\hline \multicolumn{7}{|l|}{ Out } \\
\hline Empty & 80,700 & $\$ 30$ & $\$ 0$ & $\$ 2,421,000$ & $\$ 0$ & $\$ 2,421,000$ \\
\hline Full & 181,400 & $\$ 60$ & $\$ 253$ & $\$ 10,886,000$ & $\$ 45,904,000$ & $\$ 56,791,000$ \\
\hline Transshipment & 59,600 & $\$ 42$ & $\$ 135$ & $\$ 2,503,000$ & $\$ 8,050,000$ & $\$ 10,553,000$ \\
\hline \multicolumn{7}{|l|}{ Total } \\
\hline All & 649,800 & & & $\$ 31,441,000$ & $\$ 122,364,000$ & $\$ 153,806,000$ \\
\hline
\end{tabular}

Source: Port Authority of Abidjan for throughput 2013, FEDERMAR tariffs, authors' calculations

119. The expenditure part is far more difficult to assess. To set an order of magnitude for the capital investments, a standard STS costs around \$7 million, and a typical RTG around \$2 million. In terms of operational expenditure, information on the concession fees (fixed and variable) for Abidjan is also public: $€ 12$ per loaded TEU and $€ 4$ per transshipment TEU. In addition to the variable concession fee, a fixed annual lease of $€ 22$ per sq. $m$ is applicable, i.e. $\$ 860,000$ for a $34 \mathrm{ha}$ yard. The calculations are in the table below. The figures for the other operational expenses are unknown.

TABLE 13: EstimATED CONCESSION FEe (VARIABLE) FOR ABIDJAN TERMINAL

\begin{tabular}{|c|c|c|c|}
\hline & TEUs 2013 & Fee per TEU & Total Fee \\
\hline \multicolumn{4}{|l|}{ Inbound } \\
\hline Empty & 100,600 & $\$ 0.00$ & $\$ 0$ \\
\hline Full & 169,800 & (\$13.80) & $(\$ 2,344,000)$ \\
\hline Transshipment & 57,700 & $(\$ 4.60)$ & $(\$ 265,000)$ \\
\hline \multicolumn{4}{|l|}{ Out } \\
\hline Empty & 80,700 & $\$ 0.00$ & $\$ 0$ \\
\hline Full & 181,400 & (\$13.80) & $(\$ 2,504,000)$ \\
\hline Transshipment & 59,600 & $\$ 0.00$ & $\$ 0$ \\
\hline \multicolumn{4}{|l|}{ Total } \\
\hline All & 649,800 & & $(\$ 5,113,000)$ \\
\hline
\end{tabular}

Source: Port Authority of Abidjan for throughput 2013, authors' calculations

120. Growing throughput, combined with traditionally high legacy handling tariffs, seem to generate very high returns on investment on any upgrade of brownfield terminals. The estimate for Abidjan is consistent with the high level of EBITDA reported for some global TOC (both APM Terminals and DP World for instance publish their global consolidated financial results). It is important to note however that for greenfield development, the magnitude of the investment in the infrastructure is higher as are the uncertainties on the development of the throughput. Further, large sums are tied up in the development of the facility before it can generate sufficient revenue to recoup the initial investment. It will be critical in the next phase of greenfield investments for governments to ensure not only competitive processes when auctioning the development rights for these projects but to actively seek to bring in new players into the market. In short, it is very likely that brownfield concessions operate fully with positive 
cash-flow, with investments in terminal upgrade made mostly from the revenue of the concession, while on the contrary, greenfield concessions (BOT) require upfront financing of the terminal to develop. 


\section{How to keep up with container traffic growth?}

\section{A. Future demand for container trade}

121. The future throughput of West African ports will be composed of containerized trade generated by coastal and landlocked countries, and additional port movements generated by transshipment in regional hub(s). FIGURE 17 illustrates the method used to project each component of future demand. Trade-related demand is forecast based on the historical elasticity of container trade with respect to GDP in the region and a projection for GDP growth. The allocation of container traffic across countries assumes that domestic ports are handling domestic traffic for coastal countries, a situation that is simplified by the fact that most countries have only one major container port. For landlocked countries, the allocation is based on current corridor efficiency. Overall, this method is rather crude, for instance it does not differentiate between loaded and empty containers, but is straightforward to implement, and gives sufficient indication on the magnitude of expected traffic growth for purposes of this study.

FIGURE 17: FUTURE CONTAINER DEMAND FORECASTING METHODOLOGY

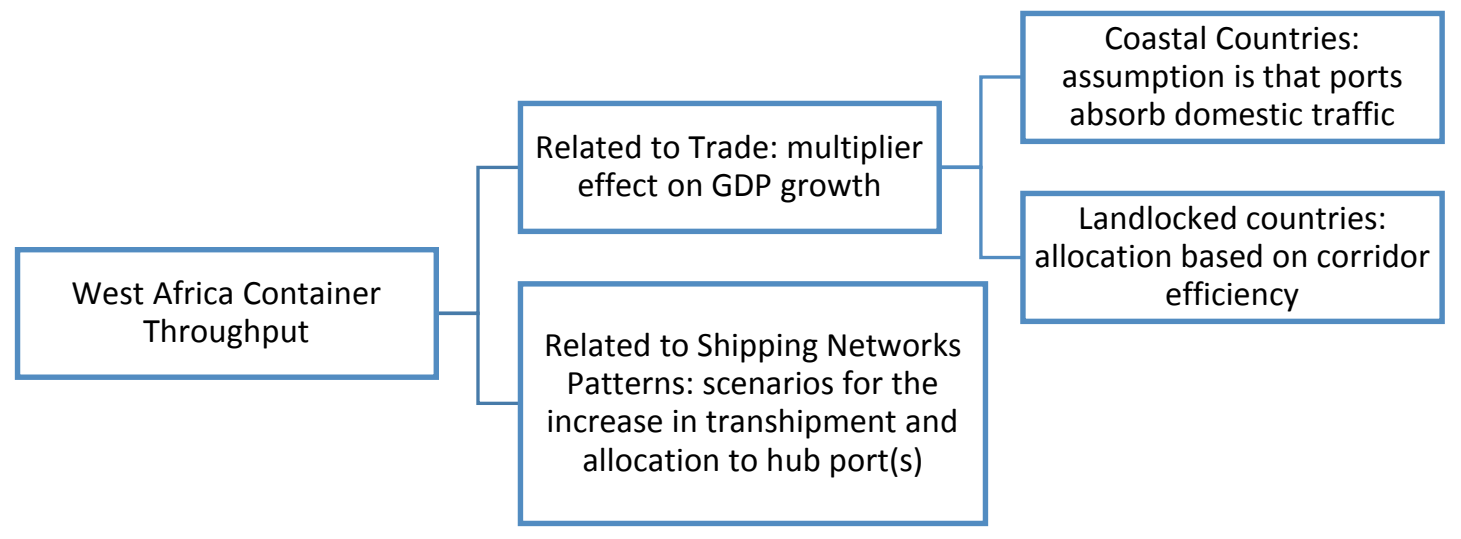

122. The rapid growth in container traffic in West Africa has been fueled by strong economic growth, with an average GDP growth of 7.0 percent for the period 1996 to 2011 . This trend, however, is not expected to continue, as recent forecast revised downwards the prospects of growth to about $6 \%$. This growth rate was associated with an average annual increase in container traffic in West Africa ports of 10.4 percent for the period 1996 to 2011 (FIGURE 18). Forecasts for GDP growth for West Africa (Table 20 in Annex 6) by international institutions (IMF World Economic Outlook database) expect this trend to slow down at $6.3 \%$ in the foreseeable future (IMF Regional Outlook October 2016, total growth for the period 2017-2020). Nigeria, subSaharan Africa's largest economy and oil exporter, has been hit hard by the oil price shock leading the authorities to cut capital spending and adjust monetary and exchange rate policies to relieve pressures on public finances. The forecast for the GDP of Nigeria were extremely volatile with 
the unfolding of the commodity crisis: Figure 25 shows the rapidly deteriorating prospects for the Nigeria economy with each revision of the IMF WEO database, between October 2014 and the latest dataset available, October 2016. As the GDP growth projections are based on an evolving economic situation in some countries, an update of the traffic projections would be warranted as the steady state growth rates become available. In this section, the latest available dataset, October 2016, was retained as basis for the traffic forecast.

FigURE 18: EVOLUTION OF GDP AND CONTAINER TRAFFIC IN WEST AFRICA

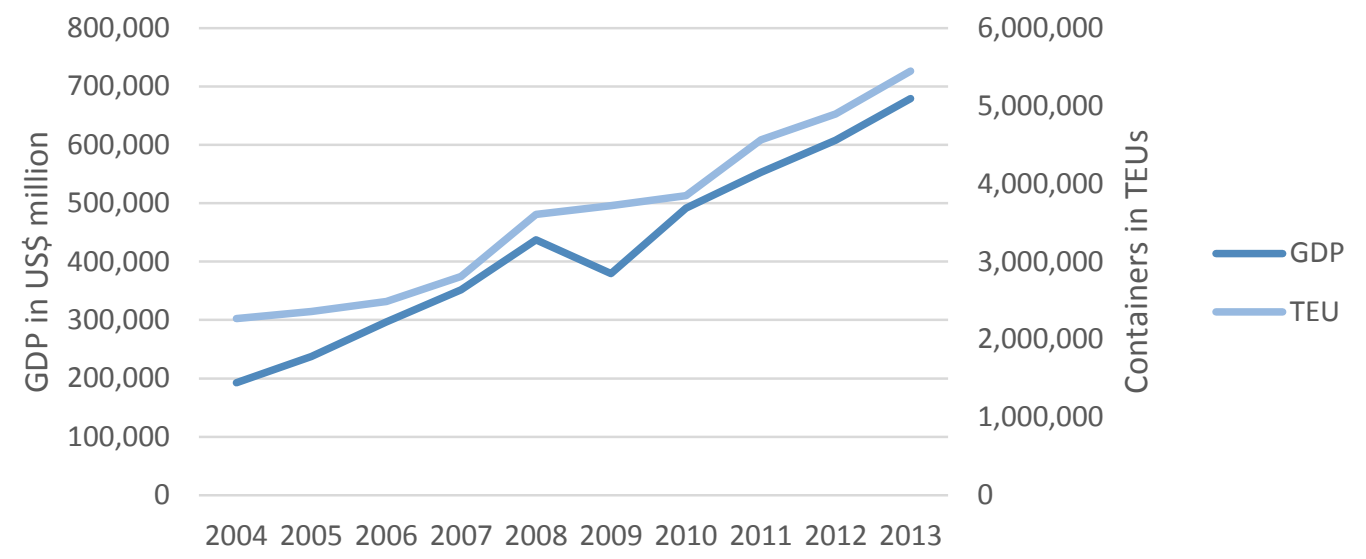

FIGURE 19: EVOLUTION OF THE IMF WEO FORECAST FOR NIGERIA GDP

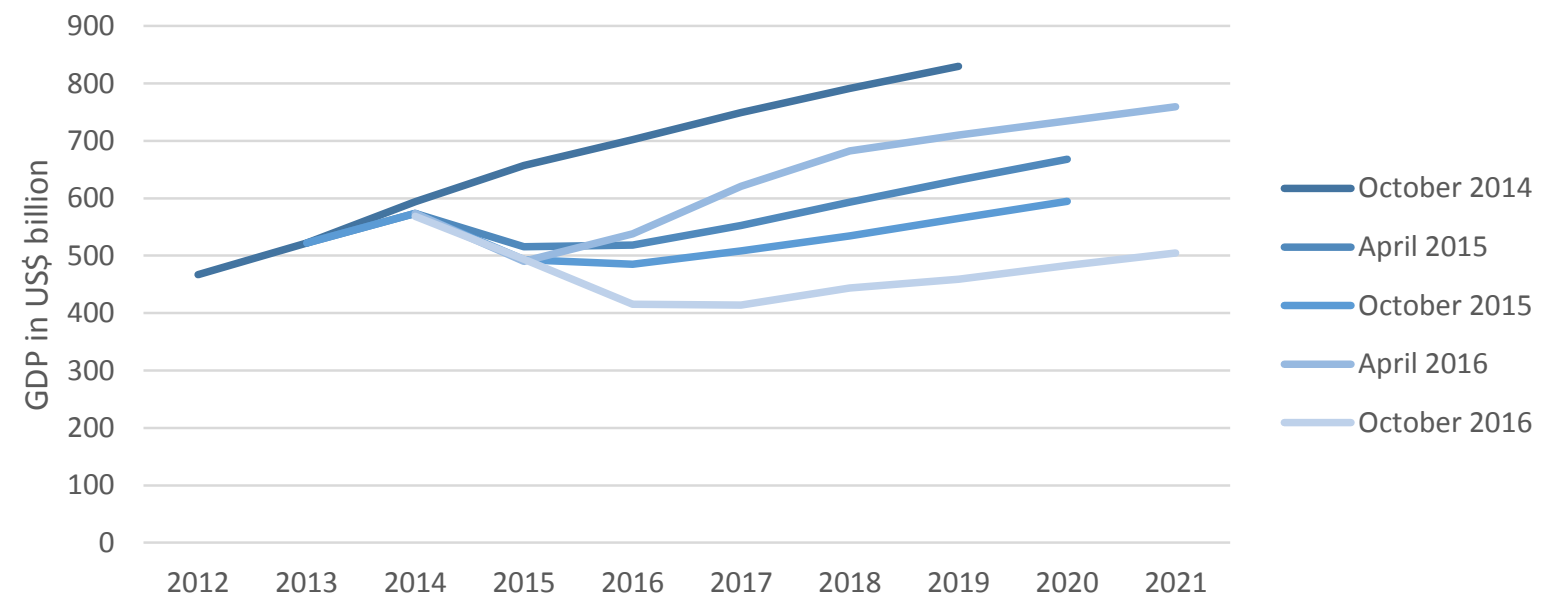

123. Different assumptions for the elasticity between GDP growth and TEU growth can lead to widely divergent forecast for future container traffic, and the data for West Africa shows large variations across countries and years which do not allow for a simple choice. For the period 1996-2011, the container growth elasticity with respect to GDP growth for the entire coastline is 1.65 (Table 21 in Annex), with two different periods, before 2006 at 2.55, in a period of modest GDP growth but sustained container growth, and after 2006 at 0.72 , in a period when the strong GDP growth was mostly driven by the commodities boom (and despite the international crisis) and more importantly by the massive adjustment in the GDP of Nigeria in 
$2013^{46}$, and the recalculation for the preceding period, while container growth maintained its steady rate. As the decomposition of container throughput into transit and transshipment was not available for 1996 data, this elasticity includes transit and transshipment containers for this year (transit was modest, and transhipment negligible) but excludes both for the 2006 and 2011 data. For the West Africa region, the GDP growth was calculated on all 15 ECOWAS countries, and port throughput including transit but excluding transhipment. There is a large heterogeneity among the values of that traffic to GDP elasticity across the different West Africa ports, and even across the years, at regional level, as illustrated in Figure 20.

FIGURE 20: TEU GROWTH VERSUS GDP GROWTH FOR 2004 - 2014

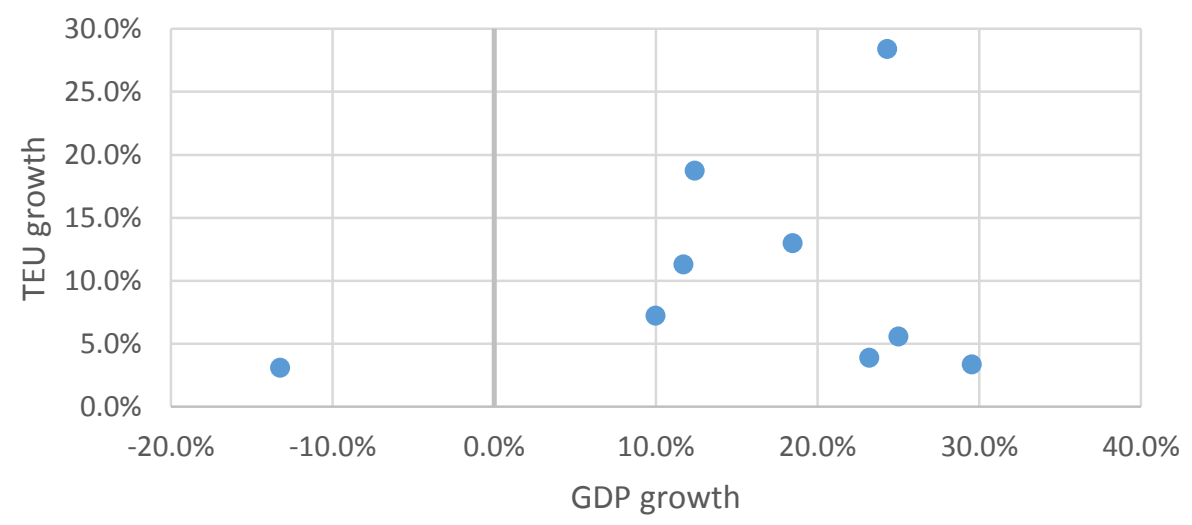

124. In comparison with other regions of the world, the calculated elasticity values are low. For the two periods 1990 to 2000 and then 2000 to 2010, the elasticity of container trade with respect to GDP for Europe remained at 3.2, increased from 1.9 to 2.4 for North America, and fell from 2.3 to 1.6 in Asia. In principle, container trade is growing faster than GDP, but there is no consistent trend, and the average multiplier has been declining over time ${ }^{47}$. Unlike Europe, North America and Asia, the West African economies are just starting to open up to the world markets. A rising share of trade in GDP would imply using a high elasticity for the traffic forecast for the period 2011 to 2025, but three points advocate for more conservative values. First, in the very recent years, the trade intensity of growth worldwide seemed to have decreased, and this phenomenon will also affect West Africa. The second is that for the West Africa countries, a large part of the GDP growth is driven by commodities, which are largely independent from container trade. The third is that, over the last decade, GDP and container trade paths are closely aligned, as illustrated in Figure 21. A conservative elasticity of 1 has therefore been retained for the forecast of the container traffic growth, but optimistic forecast with the long term regional elasticity of 1.65 have also been included for comparison.

\footnotetext{
${ }^{46}$ See for instance 'The Economist' April 12 ${ }^{\text {th }} 2014$ http://www.economist.com/news/finance-andeconomics/21600734-revised-figures-show-nigeria-africas-largest-economy-step-change

${ }^{47}$ Alphaliner Volume 2013, Issue 17. www.alphaliner.com
} 
Figure 21: Relation between GDP AND Container tRAfFic in WeSt AfricA

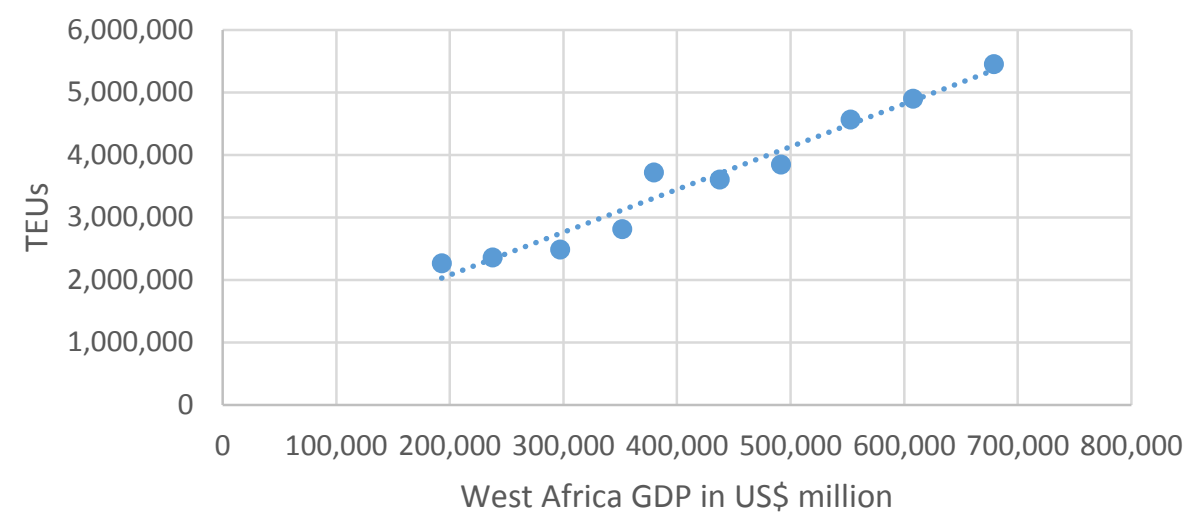

125. Based on a value of $\mathbf{1}$ for the TEU to GDP elasticity, container traffic for the coastal countries (excluding transit to landlocked countries) is projected to increase from 3.8 million TEUs in 2011 to $\mathbf{5 . 5}$ million TEUs in $\mathbf{2 0 2 0}$ and $\mathbf{8 . 0}$ million TEUs in 2025 (Figure 22). This traffic forecast is highly sensitive to the assumption for the elasticity. For instance, applying the long term regional elasticity of 1.65 (calculated for the period 1996 to 2011) to the forecast period would result in total container traffic of 13.3 million TEUs in 2025. The result with the long-term elasticity of 1.65 is more in line with the observed growth rate for container throughput over the period 1996 to 2011, which is averaging 9.9\% per year. Using the long term elasticity is resulting in a high volume scenario for the West Africa ports, but it is important to note that the current forecast is being made in a depressed scenario in which all GDP growth forecast have been revised downwards due to the drop in commodity prices.

FIGURE 22: ACTUAL AND FORECAST TRADE RELATED CONTAINER TRAFFIC FOR COASTAL COUNTRIES (EXCLUDING TRANSIT) (MILLION TEUS), ACCORDING TO ELASTICITY SELECTED

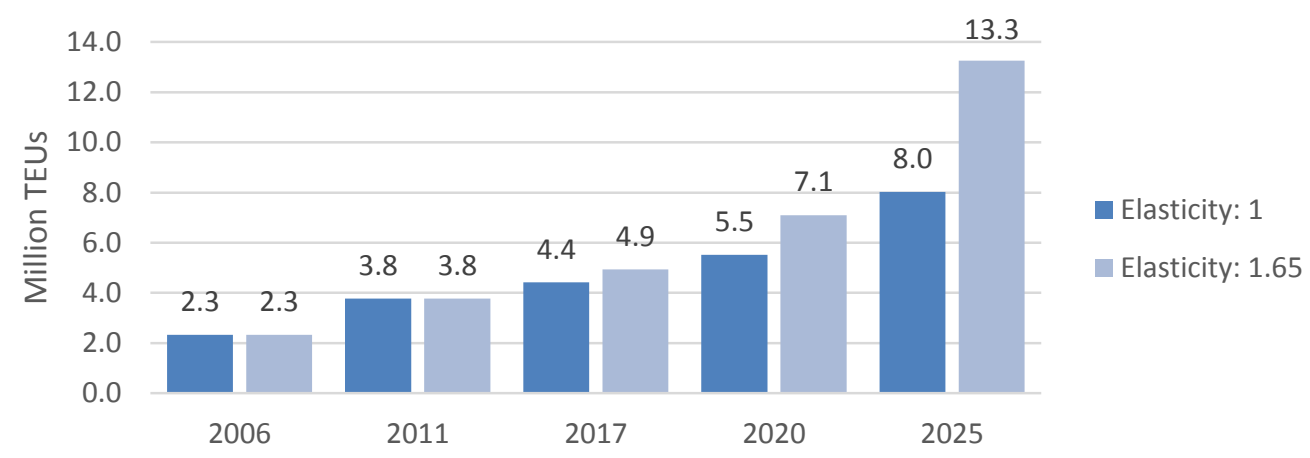

126. The transit traffic for landlocked countries is estimated in two steps. First, the total container volume is estimated for the landlocked countries using the TEU to GDP growth elasticity, and then that total volume is allocated among the coastal gateway ports. A minor difficulty for the first step is that transit traffic with the West Africa landlocked countries is only available in tonnage, and very rarely in TEUs (most containers are stripped at the ports). A 
conversion factor, tons to TEU, will therefore be applied first to enable forecast of the total container traffic linked to GDP growth. The allocation of transit traffic to each port depends more on the respective competitiveness of the entire corridor than just the individual port in which it originates or end. In a study for the World Bank ${ }^{48}$, Nathan (2013) analyzed the competitiveness of the main West Africa corridors in terms of price to the shipper and delays. The parameters of that analysis were factored into a model for the selection of the corridor, and hence the coastal gateway. The model used the following variables: (i) distance as a proxy for transport costs, (ii) the number of border crossings as a proxy for hidden costs and transit time, (iii) the UNCTAD Liner Shipping Connectivity Index (LSCI) as a proxy for maritime costs and quality of service, and (iv) the natural log of the container throughput as a proxy for Mohring (or agglomeration) effects. However, based on the transit traffic reported by ports, the calibration of the model on the four variables showed that the only significant variable was distance.

127. The difficulty in relying on this model is that political considerations, and the condition of the inland transport network, are often more important than efficiency considerations when selecting a given corridor. For example, the share of Abidjan, Tema and Lomé for transit goods to Burkina Faso fluctuated greatly during the 1998 to 2013 period (Figure 23) in response to developments in the Ivoirian crisis, as well as the enforcement of axle load limits in Ghana, road damage in Togo, major changes in customs procedures in Benin, and the global recession which reduced traffic volumes across corridors. By contrast, a model based on distance, and including the other variables initially tested, would have resulted in a more stable allocation. However, none of these events can easily be used to estimate the determinants of the choice of port for transit traffic, and even if they could, the future value of such variables could not reliably be forecast.

FIGURE 23: EVOLUTION OF THE ROUTING OF THE BURKINA FASO MARITIME TRANSIT TRADE

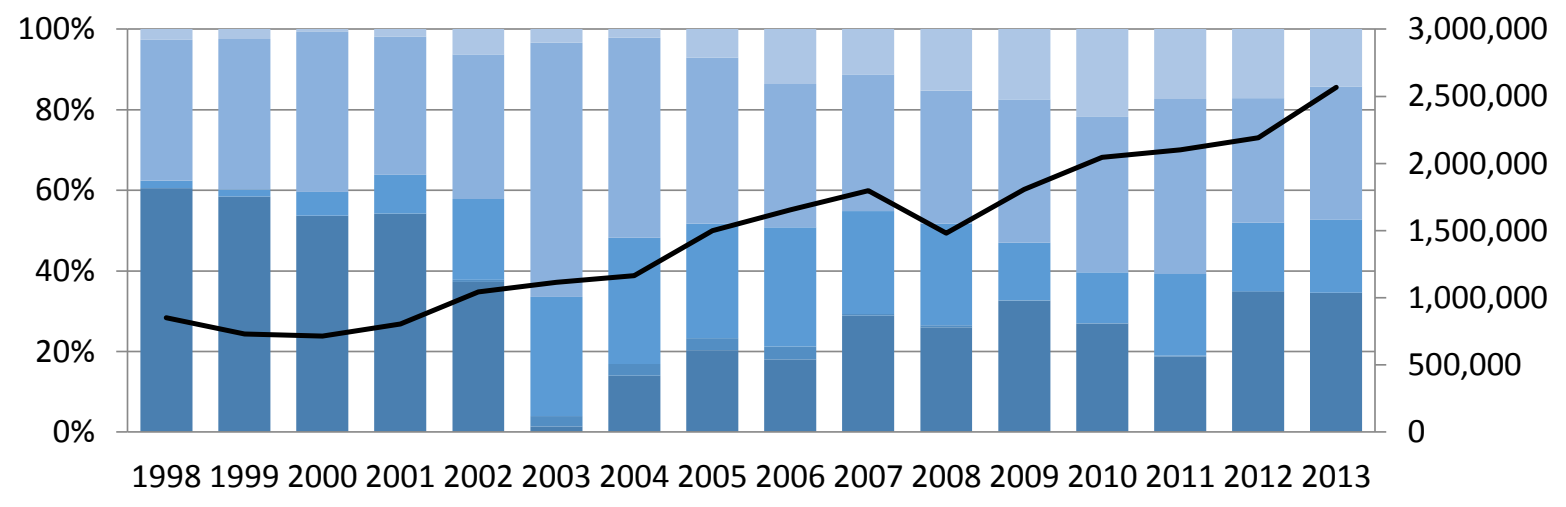

Abidjan Takoradi Tema Lome Cotonou Total

${ }^{48}$ Logistics costs in Central and West Africa, SSATP 2013. 
128. Maritime transit traffic is forecast to rise strongly over the next $\mathbf{1 0}$ years, flowing through the established regional gateways. Using the same assumptions on the container elasticity with respect to GDP and the GDP growth forecast applied to the past container traffic for the landlocked countries, maritime transit is expected to grow from 0.4 million TEUs in 2011 to 0.8 million TEUs in 2020, and 1.6 million TEUs in 2025 under the long term elasticity (Figure 24). This compares to 1.0 million TEUs in 2025 using an elasticity of 1 . Considering the limitations of the corridor choice model for the allocation of the traffic to the respective maritime gateways, the maritime transit of the landlocked countries is allocated according to the recent market shares, corresponding to a more stable period (post Ivorian crisis): Mali predominantly relies on Dakar (60\%), and to a lesser extent Abidjan (40\%); Burkina Faso predominantly relies on Lomé (50\%), followed by Tema (30\%) and then Abidjan (20\%); and Niger predominantly relies on Cotonou (80\%), and to a much lesser extent Lomé (20\%).

FIGURE 24: TRAFFIC FORECAST FOR LANDLOCKED COUNTRIES

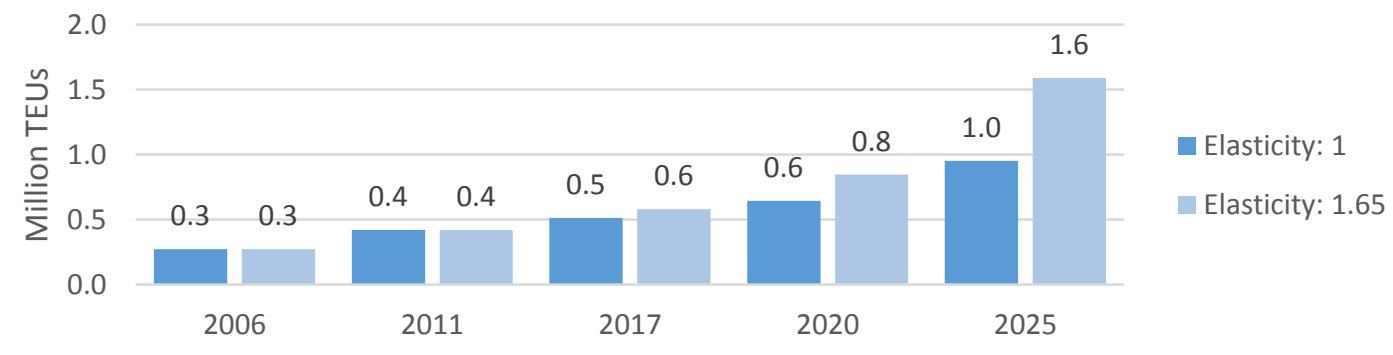

129. Combining the trade-related container growth for coastal and landlocked countries (worst case scenario), the traffic for West Africa is projected to reach almost 6.2 million TEUs in 2020 and 9.0 million TEUs in 2025, or a little more than two times its level in 2011 (Figure 25). This total still excludes transshipment, which needs to be estimated through a different method. As pointed out, the uncertainty on the elasticity results in widely different scenarios, but all confirm a growth in traffic that largely exceeds current container capacity.

Figure 25: Projected CoAstal AND LANDlocked Container trafFic

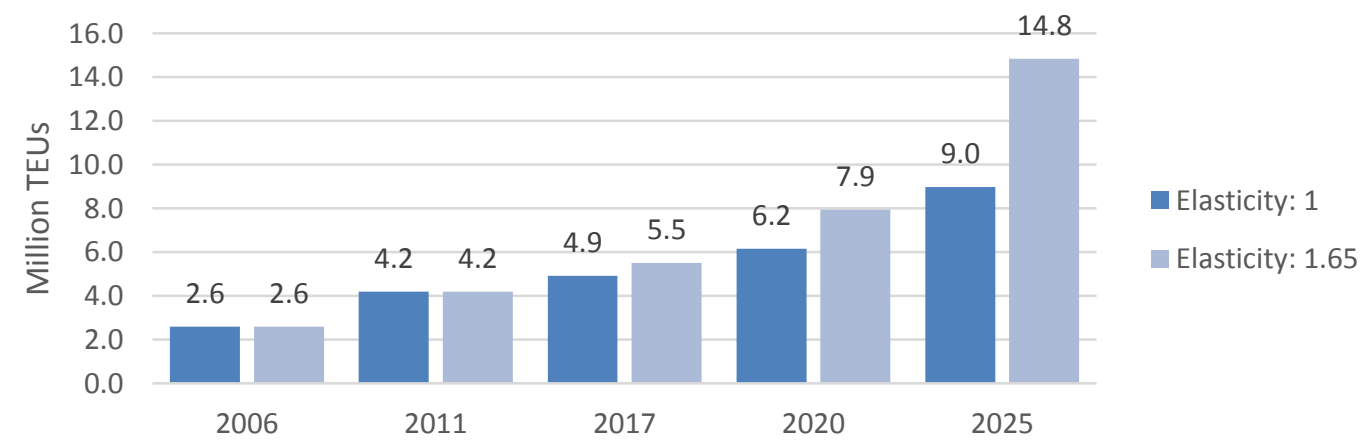


130. Forecasting transshipment volumes is even more dependent on the scenarios. Shipping lines' strategies drives transshipment. Under the pressure of costs, shipping lines have transformed the manner in which trade lanes are served, with ever-larger vessels and networking of services between trunk lines and feeder services (a hub and spokes network). Along the main East-West trade lanes, a number of hubs emerged where containers were transshipped on regional services, taking advantage of the economies of scale brought by much larger vessels on the deep-sea haul. However, the shift towards a hub and spokes network has never been integral, and most trade lanes are still served by a combination of end-to-end service, limited to connecting two ranges of ports, and transshipment services. Moreover, the situation has never been static, and volume growth on the various trade lanes dictates the balance between end-toend and transshipment services. To maintain their profitability, liner operators are in a constant process of adapting to changes in market conditions. In West Africa, what was not economically sensible before the transformation of the container terminals when port access limitations were limiting the economies of scales of transshipment (see Palsson 1998) is now becoming a reality, notably with the emergence of Lomé as the transshipment hub for MSC on the Asia West Africa trade.

131. Transshipment volumes are likely to rise, but by how much? Increasing transshipment by West African ports would have a significant impact on measured maritime trade volumes: when the transshipment hub is outside of West Africa, each container trip generates only one full movement in one of the West Africa ports. When transshipment takes place in West Africa, the final trip still generates one full movement in one port, but also two full movements in one hub, or three movements in total for each trade-related container movement. In the past, transshipment volumes in West Africa were limited, 83,000 TEUs in 2006 and 372,000 TEUs in 2011, respectively 3.3 percent and 9.2 percent of the trade-related traffic in the region (coastal and transit containers included). With the changes in the liner shipping patterns discussed above, this share will increase. Regions located along the main East-West shipping lanes display a high ratio of transshipment to total traffic: in 2013, this ratio reached $45 \%$ for Mediterranean ports, $52 \%$ in Central America and the Caribbean, 46\% for Arab Gulf ports, and 50\% for South East Asia. In more isolated areas, however, this ratio is low: $10 \%$ in the Scandinavia / Baltic Sea area, and $10 \%$ in South America. West Africa lacks the advantage of proximity to the main shipping lanes, so the ratio of transhipment to total traffic is likely to remain lower than in the more transhipment-intensive regions. A conservative estimate is that the transhipment level could rise to $25 \%$ by the year 2025 (a level of $20 \%$ was used for 2017 and $22 \%$ for 2020 ). This represents a jump compared to past levels, but in the year 2015, transshipment in the port of Lomé reached 650,000 TEUs and 124,000 TEUs in San Pedro (the two ports where most of the transhipment is taking place in West Africa), compared to the 372,000 TEUs for all ports for the full year 2011. Considering that shipping lines tend to follow innovations from first movers, and that planned greenfield terminal development rely heavily on transhipment, the level of $25 \%$ seems realistic. However, different scenarios could be tested. 
FigURE 26: CONTAINER TRAFFIC FORECASTS (COASTAL, LANDLOCKED, AND TRANSSHIPMENT)

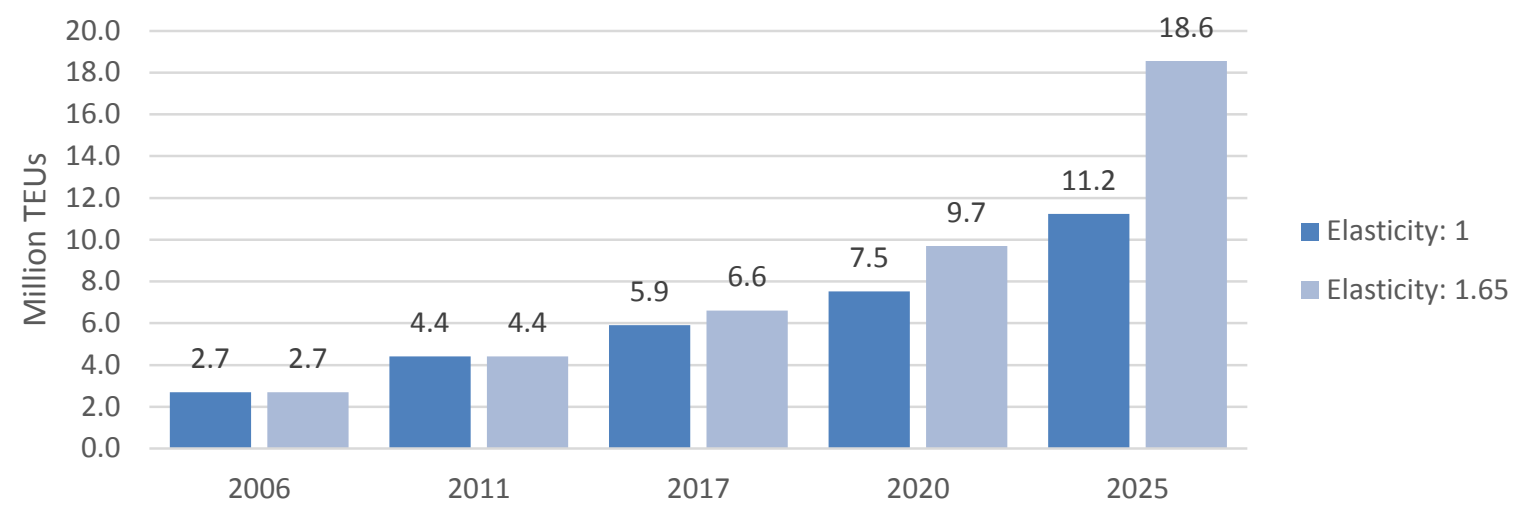

132. In summary, projected growth of the container throughput in West Africa shows that compared to 2011 levels, activity will likely be multiplied by almost three by 2025 - in the worst case scenario --, providing the justification for new investment in port terminals (Figure 26). Such growth will put a strain on existing capacities, and even though productivity is low by international standards, capacity reserves that could be unlocked by improved performances would not be sufficient to accommodate a growth of that magnitude. This will require expanding terminal capacity in existing ports, and also develop new ports, justifying the pipeline of port projects already announced by port authorities and terminal operating companies, just to keep up with traffic growth.

\section{B. Capacity development plans by TOCs}

133. In the longer term, capacity development is essential to meet expected traffic growth. Terminal operators and Government already have laid out ambitious plans to develop new container facilities, in both existing and new ports (cf. also Map 1). The main difference with the investments during the first phase of terminal concessions is that the ambition is to develop new terminals, and not simply modify and upgrade existing terminals. The magnitude of the investments and the capacity created are therefore of a different order, several hundreds of million US dollars in investments and increases in capacity to levels measured in millions of TEUs per year, as illustrated in Table 14. These projects are at very different development stages: some are already operational, such as LCT in Lomé; others have already signed MoUs clarifying the time frame and the scope of the projects; and others are still at the planning stage.

TABle 14: SeleCted EXAMPLES OF LARGE CAPACITY DEVELOPMENT PROJECTS

\begin{tabular}{ll} 
Port and terminal & Announced investment \\
\hline Lomé - LCT & $€ 352$ million (terminal operator only) \\
\hline Abidjan - TC2 & 466 bn FCFA (Port authority) and $€ 400$ million by \\
& Terminal operator \\
Badagry (Nigeria) & US\$2 billion to US\$3 billion
\end{tabular}

Future capacity

2.2 million TEUs

1.5 million TEUs

Badagry (Nigeria) US\$2 billion to US\$3 billion

1.8 million TEUs 
134. Not all existing ports are suitable for the development of new terminals, and in future, new port sites will need to be identified to accommodate capacity growth. To allow for the development of new terminals within the existing port limits, a port must meet several criteria: (i) adequate nautical access to accommodate ships with deep draft and sufficiently large turning basin to enable safe movement of long vessels, (ii) land reserves that offer sufficient space for the development of new quays and yard areas, and (iii) good connectivity and access conditions on the land side, i.e. not be hemmed in by urban congestion. Part of the reason why TOC are promoting the creation of new ports in the east and west of Lagos rather than expanding the existing facilities is indeed to avoid urban congestion, and similar constraints exist for Conakry. On the other hand, Abidjan, Dakar, and Lomé, for instance, have the breathing space required for developing new terminals within their current limits.

135. The major capacity development projects will require complementary investment in the nautical infrastructure, which is traditionally the responsibility of the public sector. Even for ports which have sufficient land and marine reserves to accommodate new terminals, such as Abidjan or Lomé, the development of new terminals will require extension of the protection infrastructure facing the sea, deepening of the access channel, and extension of the turning basin. For the ports developed in greenfield sites, such as Lekki and Badagry, a completely new nautical infrastructure needs to be created. Although West Africa, following the trend everywhere else in the world, has given TOCs a greater role in the management and financing of the container terminals, the provision of nautical infrastructure remains the responsibility of national or regional public entities ${ }^{49}$. Consequently, in addition to terminal operator investments, a significant amount of public investment, either funded by the port authority or the national or local governments, will be required for the concomitant upgrade or creation of the nautical infrastructure.

136. To the difference of the first wave of container terminal concessions, in which TOC were providing the financing for the upgrade of the terminals, the new wave will require financing from the public institutions, which may be problematic in some countries. In addition to the port facilities themselves, investment in road transport infrastructure is likely to be needed to connect the new port to the existing transport grid, and this is also the responsibility of the public sector. For instance, in Abidjan, it has been envisaged that the TOC would finance a significant part of the infrastructure, but ultimately, that responsibility was transferred to the Port Authority of Abidjan, which will finance dredging, Vridi canal expansion, land reclamation and the quay wall, at an estimated cost of US\$800 million. The TOC plans to spend around US\$400 million on the infrastructure and superstructure of the terminal (which includes the handling equipment). In the case of Ghana, the solution to the shortage of resources has been to tilt the balance

\footnotetext{
${ }^{49}$ Ministries, provincial or regional governments, port authorities
} 
between the respective responsibilities of the terminal operator and the public entities. In the presentation of the extension, it is specified that the terminal operator will develop the four deep-water berths, the new breakwater and the deepening of the access channel, which should at least in part be the responsibility of the port authority and Government of Ghana. The fact that an additional portion of the public burden, the upgrade of the Tema Accra highway to a six lanes highway, has been shifted to the terminal operator, is another indication of the limits on the availability of public resources to finance the extension of the port.

137. So far, access to finance for TOC has not been a binding constraint, largely because container terminals are very profitable businesses. Financial accounts of individual terminals are not public, but global TOCs usually publish their financial results: APM Terminals' website reported global 2014 revenue of US\$4.45 billion and after-tax profit of US\$900 million, invested capital of US\$5.93 billion (a return on invested capital of 14.7\%), and a 38.3 million Equity TEU throughput. DP World reported a 2014 revenue of US\$3.41 billion, an EBITDA of US\$1.588 billion (i.e. 46.6\% EBITDA margin), and profit of US\$757 million for a throughput of 28.3 million Equity TEUs. Bolloré Africa Logistics publishes financial results, but these also reflect railway operations, C\&F agencies, inland terminals, etc. and do not isolate container terminal concessions. The portfolio of global TOCs such as APMT and DPW combines brownfield projects, with established revenue streams and minimal requirements for investments, and greenfield terminals, with more uncertain revenue streams and comparatively larger investment requirements. Overall, the global revenue per equity TEU for APM Terminal and DP World are very similar, \$116 per equity TEU for APMT and \$120 for DPW. The level of profitability reported on worldwide operations is likely to be much lower than in West Africa, where so far most of the portfolio of the TOCs concerns brownfield concessions. The estimate of the revenue of the Abidjan container terminal in Table 12 shows a revenue of $\$ 236$ per TEU, which seems to corroborate the hypothesis that profit margins in West Africa are higher than worldwide averages.

138. However, with the balance between brownfield and greenfield terminal concessions shifting towards greenfield developments, the financing model of the TOC will need to change. It has been suggested earlier that investment commitments under the first wave of concessions were largely met through the revenue generated by the concession itself, but this will no longer be the case for greenfield developments. Combined with the magnitude of the investments required for the development of the new container capacity, TOC will need to mobilize external resources. For instance, in 2013, the IFC provided a loan valued at US\$116.2 million and led the consortium of financiers, including AfDB (African Development Bank), Germany's DEG, Netherland's FMO, the OPEC Fund for International Development, and France's PROPARCO, that structured the debt package for an amount of $€ 225$ million for the Lomé Container Terminal (LCT). It is important to note that even in the case of brownfield concessions, the TOC may has had to mobilize external resources, as illustrated in the US\$293.66 million investment by DP World for the Dakar Container Terminal which was part direct equity from DPW (US\$99 million 
DPW Dakar, US\$65.36 million DPW) and part debt, US\$42.5 from commercial banks, and US\$86.80 from IFIs ${ }^{50}$.

139. Overall, both the public entities (port authorities, local and national governments) and the terminal operators will need support to mobilize the resources required for these investments. There is a possible role for IFIs in implementing a "cascade" approach to look at funding options from the private sector and if/as needed with complementary public input. In the case of DP World investment in Dakar and LCT in Lomé, and more recently for the extension of the Tema, IFIs provided significant portions of the debt component. The structure is equally complex for the public entities' component of these projects. For instance, for the Lekki port (the only example of a pure greenfield operation for which sufficient details have been made public), the Lekki Port LFTZ Enterprise (LPLE) responsible for the development of the infrastructure is a special purpose vehicle led by the Tolaram Group, which will also include the Nigerian Port Authority (NPA), the Lagos State Government and an Investment Holding Company incorporated to hold the non-Nigerian governmental interests in LPLE. The Tolaram Group is expected to hold a beneficial interest of up to $45 \%$ in the project, while the NPA and Lagos State Government are expected to hold approximately $20 \%$ each, with the remainder corresponding to the investment holding company ${ }^{51}$. LPLE entered into a sub-concession agreement with International Terminal Container Services ${ }^{52}$ for the container terminal component of the port project. The equity and debt structure is not yet known, but considering the magnitude of the investments, around US\$1 billion for LPLE and around US\$300 million for the terminal operators, the debt component is likely to be significant for both, and primarily sourced from IFIs. In Abidjan, the second container terminal will be developed in the land reserve of the port authority, which minimizes the need for marine infrastructure investment, but still requires deepening and widening the access channel. The port authority, financed by a 395 billion CFA franc loan from EXIMBANK and 70 billion CFA franc loan from the Government of Cote d'Ivoire, will undertake this project investment of 466 billion CFA francs ${ }^{53}$.

\section{Long term adequacy between planned capacity and forecast demand}

140. Planned investments would expand regional container terminal capacity in West Africa to above 20 million TEUs by 2025, which is close to the regional traffic forecast in the best-case scenario above. Table 15 provides an overview of capacity developments for the West Africa

\footnotetext{
50 Private Infrastructure Development Group profile on the Dakar concession, http://www.pidg.org/resourcelibrary/case-studies/pidg-case-study-dakar-container-terminal.pdf

${ }^{51}$ www.lekkiport.com

${ }^{52}$ CMA-CGM later acquired a $25 \%$ stake in the terminal

${ }^{53}$ http://www.jeuneafrique.com/4561/economie/largement-financ-par-eximbank-le-port-d-abidjan-chercheencore-quelques-milliards/
} 
ports, based on the information available ${ }^{54}$. Assessing future terminal capacity at a regional level on the basis of planned investments is a speculative exercise, as the phasing of capacity development can change over time ${ }^{55}$ and new projects can suddenly appear ${ }^{56}$. However, assuming adequate financing from both public and terminal operators is available, the total planned capacity is very close to the forecast demand. The evolution of container traffic in the few coming years will be critical in determining which scenario is emerging: in the low elasticity hypothesis, some planned developments are likely to be delayed, whereas if the strong growth scenario is confirmed, the currently planned development will not be sufficient.

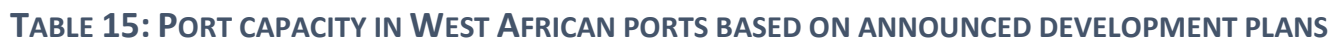

\begin{tabular}{|c|c|c|c|}
\hline Port / Terminal & Capacity 2013 & Capacity 2015 & Future capacity \\
\hline Dakar & 600,000 & 600,000 & $2,100,000$ \\
\hline \multicolumn{4}{|l|}{ Banjul } \\
\hline \multicolumn{4}{|l|}{ Bissau } \\
\hline Conakry & 230,000 & 250,000 & 600,000 \\
\hline Freetown & 75,000 & 150,000 & 750,000 \\
\hline Monrovia & 100,000 & 100,000 & 200,000 \\
\hline San Pedro & 500,000 & 500,000 & 500,000 \\
\hline Abidjan SETV & 850,000 & $1,100,000$ & $1,200,000$ \\
\hline Abidjan TC2 & & & $1,500,000$ \\
\hline Tema & 850,000 & $1,000,000$ & $3,500,000$ \\
\hline Lomé Togo Terminal & 580,000 & $1,200,000$ & $1,200,000$ \\
\hline Lomé LCT & & & $2,200,000$ \\
\hline Cotonou multipurpose berths & 480,000 & 480,000 & 480,000 \\
\hline Benin Terminal (Cotonou) & 220,000 & 600,000 & 600,000 \\
\hline Badagry & & & $1,800,000$ \\
\hline Lagos Apapa & 600,000 & $1,000,000$ & $1,000,000$ \\
\hline Lagos Tin Can Island & 600,000 & 880,000 & 880,000 \\
\hline Lekki & & & $2,500,000$ \\
\hline Total: & $5,685,000$ & $7,860,000$ & $21,010,000$ \\
\hline
\end{tabular}

141. While forecast capacity is sufficient to meet expected demand at a regional level, adequacy at a more local level is not ensured. The method used for forecasting future container traffic can allocate growth to individual ports for coastal and landlocked countries trade related traffic, but not for transshipment, which ultimately depends on the strategies of the shipping lines and the emergence of greenfield hubs. For instance, the traffic forecast for Nigeria ports, close to 3 million TEU in the best-case scenario, is still far less than the combined planned capacity in Lagos, Lekki and Badagry (5.7 million TEUs). It is therefore likely that the phasing of the development of existing projects will be adjusted to take into account both the evolution of the

\footnotetext{
${ }^{54}$ As of October 2015

${ }^{55}$ The first announcements for Badagry were putting the start of the construction work in 2012, but in practice, the project is still in discussion

${ }^{56}$ Notably the announcement of the development of a 750,000 TEUs terminal in Freetown, in September 2015.
} 
demand and competition from neighboring terminals. This adjustment may lead to postponing investments if demand softens, or to developing new projects if demand increases as expected. Another area where adjustments are likely is the center part of West Africa, where the planned capacity exceeds forecast demand, even if the demand from landlocked countries is routed through these ports (see Figure 33).

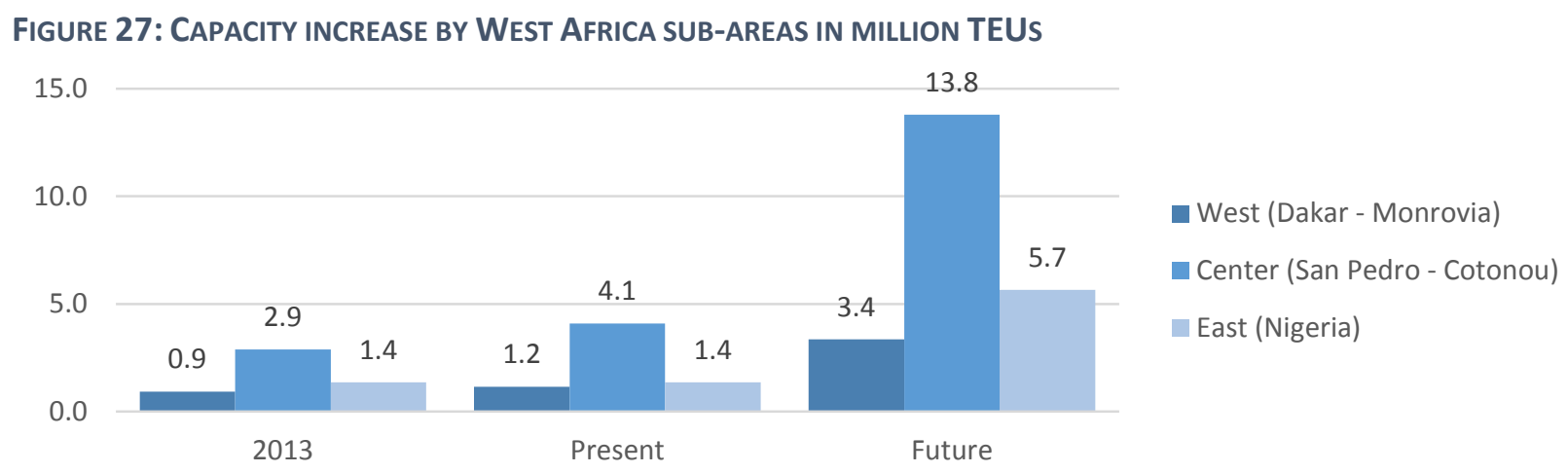

142. It has been mentioned earlier that as existing ports get closer to capacity, greenfield ports with higher development costs will be inevitable. In many cases, these ports could be located in less favorable sites requiring higher investments in both the port and connecting land transport infrastructure. The megaprojects for container terminal developments - Tema, Lekki and Badagry - also all include dedicated terminals in order to share the massive nautical infrastructure that will be required across a larger user base. Planned investments in Lekki and Badagry, for instance, include tanker terminal and tank storage, as well as a free zone to enhance the financial and economic viability of the project.

143. In the best case scenario, with a forecast traffic of $\mathbf{1 8 . 6}$ million TEUs at the $\mathbf{2 0 2 5}$ horizon, and growth rates estimated at a minimum of $5 \%$ per year, it would be necessary to add close to 1 million TEU to the existing capacity annually simply to keep up with the demand. Estimating the cost to create that capacity depends on numerous factors: can this done by lengthening existing quays from an existing terminal, can this be done by creating a new terminal in an existing port, or does this require an entirely new port, and if yes, what additional inland infrastructure will be required to connect it to the regional transport network? Depending on the answer to these questions, the cost of creating such capacity can vary between a couple of hundred million dollars and a couple of billion dollars over the next decade.

144. A strict quantification of the resources required is therefore challenging but an order of magnitude estimate would put the resource requirements at around half a billion dollars per year, with contributions necessary from both public and private sources. This assessment is based on comparisons with existing projects and the assumption that with time, more and more terminals will be created in pure Greenfield sites as existing ports fully utilize their land reserves. 
In Freetown, Bolloré (BAL) plans to develop a 750,000 TEU terminal for $\$ 120$ million. This is the lower end of the cost estimate, with the conversion and expansion of existing quays into a container terminal. Higher up in the scale, the Abidjan TC2, a new terminal harbored in an existing port, and therefore benefiting from existing marine infrastructure that does not require major work, the total investment will reach $\$ 1.2$ billion with the port authority contributing $\$ 750$ million, and the TOC around $\$ 450$ million. This will finance a design capacity of around 1.5 million TEUs (refer to Table 14). Even further up the scale, a pure greenfield facility, such as Badagry, may cost twice this amount, for an equivalent capacity. 


\section{Conclusions and Recommendations}

145. Reform in the management and operations of container terminals through concession agreements with the private sector has generated improvements in the performance of the sector though benefits have been limited and not evenly distributed. The private sector has delivered critical sector improvements by converting poorly equipped terminals or multi-purpose berths into modern container terminals of international standards. Modern handling equipment such as STS cranes and conversion of yard operations into RTGs has reduced congestion and released capacity allowing ports to meet the rapidly increasing demand seen in West Africa over the past decade or so. From a government perspective, the takeover of container terminals by Terminal Operating Companies has shifted the terminals from the realm of problems to sources of income.

146. Despite clear benefits, the transformation of the West African ports remains incomplete. The bulk of the benefits have been realized from relatively easy modifications implemented by operators while government has skirted the structural reforms necessary for deeper and longer lasting change. Operators have relied on scale efficiencies or technological progress (e.g. increase in capacity and upgrades or purchase of new equipment) for productivity improvements with few advances in organizational and operational efficiency at the terminal level. Importantly, TOCs have seen a reduction in unit costs linked to the combination of growth in traffic and a high proportion of fixed costs in their cost structures. These reductions have not, however, been passed on to the final customers, the shippers, of the container terminals and sparingly shared with the conceding authorities. While cargo-handling tariffs in a few West Africa ports remain amongst the highest in the world, e.g., Dakar and Abidjan, a wide disparity is observed in the region with some port tariffs at par with international comparators, e.g., Cotonou.

147. The arrested transformation of the ports sector can be traced to the West African institutional and governance framework as well as the economic characteristics of the CT industry. There is a double asymmetry between (i) the countries of West Africa which lack deep experience, tools and frameworks for managing and regulating private sector firms and the international TOCs, and (ii) atomistic shippers and TOCs in an industry which is naturally monopolistic. The poor governance frameworks and inadequate regulation exacerbate the concentration of market power and help explain the situation in West Africa.

148. Policies which harmonize regulatory oversight of monopolistic activities with fostering competition will do much to improve the economic outcome of private sector involvement in the port sector. In other parts of the world, the potential market power of TOCs is checked through a combination of inter and intra- port competition, together with effective regulation. Ex-post, inter-port competition in West Africa is currently hindered by barriers to inland transport 
and cross-country movement of traffic and goods which impact the availability of contestable hinterlands while ex-ante, intra-port competition is possible only in a few ports where traffic is high enough to support more than one operator.

149. These limitations may be overcome if there is, for example, sufficient competition for the market (by auctioning the right to operate a port or operate within a port) which allows transfer of any monopoly rents to the state through the tendering process. Equally, depending on the criteria for the award of the concession, the conceding authority could decide to limit tariffs rather than maximize revenue to the state again improving the outcome. Competition for the market occurs at discrete points in time while performance improvements can also be built into, and enforced via, good contract documents and appropriate management through the life of the concession. To obtain these results, the focus has to be on (i) improving the concession process, (ii) getting the competition framework right, and (iii) strengthening the concession contract documents. In addition, competitive outcomes can be achieved through an assessment of the relative and absolute performance of each concession, that is, (iv) yardstick competition.

150. With the growth of port traffic and the upcoming renewal of existing concessions, it is critical to revisit now the concession process to better manage the next wave of concessions. Adequate resources need to be set aside to access the necessary expertise to supplement public capacity to negotiate concession agreements, to consider barring incumbent operators from bidding for additional terminals in a given port, to conduct transparent bidding processes which allow fair competition for the market and offer equal opportunities to new entrants, and to recalibrate the criteria for contract award towards economic impact as opposed to pure financial returns. In certain circumstances a negotiated process could be warranted notably when TOCs and shipping lines join forces to promote a transhipment terminal.

151. There also has to be clarity in who is responsible for regulating the $\mathrm{CT}$ concessions. There are alternative options to dedicated competition authorities: at regional and national level several existing institutions have some form of mandate in transport and corridor performance (regional economic communities, corridor institutions, industry associations, facilitation committees etc.). Countries and RECs which established them should expand their mandate to include port terminal concession oversight and tariff regulation.

152. Strengthening the concession contract documents for future concession, while improving what can be improved in the current ones. When appropriate, irrespective of the process employed to contract a concessionaire, revision of current contracts documents - as part of the renegotiation clauses if and when they exist, may be considered by Governments to reduce port tariffs, improve competitiveness, and allow meaningful monitoring of performance. Such revisions should improve the distribution of benefits amongst stakeholders: reduction in tariffs could reduce government revenues but would benefit shippers and generate positive spill over effects into the local economy. Since there is an inherent asymmetry of power and negotiating 
capacity between the ultimate clients of the ports and the TOCs, systematically disclosing operational and cost information to the general public provides an opportunity to bring together the virtual constituency of regional port users.

153. Transparency and Regional Comparisons. Generalizing the publication of tariffs and key performance indicators is the first step to improve transparency and facilitate policymaking. Then one could think of ways to formalize customer feedback loops by including specific provisions to this effect in concession agreements, complemented by mandatory disclosure provisions. The data collected through these systematic feedback processes at the local port level could then form the basis for a region-wide database that would allow meaningful comparisons between facilities and also hopefully nurture some emulation between them.

154. Improved Concessions Performance Indicators Monitoring. Currently productivity measures included in contract documents are ad hoc, partial and ill-defined and can often be misleading in their ranking of ports (Estache et al). Explicit and standardized measures of efficiency such as productivity (output versus time) and cost effectiveness (output versus cost) have to be developed. Collecting and publicizing data on these indicators over a period of time will permit benchmarking the relative and absolute performance of each concessionaire and further competition through comparison.

155. Regional perspective. In order to avoid costly port overcapacity, their future development should be essentially driven by the market, which - most likely -- implies a few regional port hubs servicing the other smaller ports through short sea shipping services. Both ECOWAS and PMAWCA are interested to provide guidance to their country members with a view to optimize the port network along the West Africa Coast. Actually, two studies have just been commissioned by the ECOWAS for that purpose: (i) The socioeconomic of port concessions study (CPCS Consult of Canada to start in July/August 2017); and (ii) the Development of a maritime and port infrastructure master plan for West Africa (MTBS Consultants, started in May 2017).

156. This study has opened the doors for a fresh understanding of the container terminal business in West Africa and identified areas for further analysis. A deeper understanding of the channels of development impact of the port industry in all of Sub-Saharan Africa is warranted to identify opportunities for maximizing the positive outcomes for the region and the business communities. The next phase of this work should therefore: (i) analyze the welfare impacts of prices, quality and service levels seen in the concentrated container terminal markets of SSA and select international comparators; (ii) map the interlinkages between the port sector and the national local economies, and (iii) situate the findings and recommendations in a global context. 


\section{References}

AfDB. 2010. Reforms and the Regulatory Framework of African Ports. Chapter 3 in African Development Report 2010. African Development Bank.

AICD. 2009. Beyond the Bottlenecks: Ports in Africa. Africa Infrastructure Country Diagnostic, Background Paper 8. Washington DC: The World Bank.

Alix. Yann. 2015. Logistique : une nouvelle révolution est nécessaire. Jeune Afrique, 26 February. Available at: http://economie.jeuneafrique.com/tribune/426-tribunetransport/24207-logistique--une-nouvelle-revolution-est-necessaire-.html

Alix, Yann. 2011. Growing containerised trade between West Africa and European and Asian economies. UNCTAD Trade Logistics Branch, Division on Technology and Logistics Transport Newsletter, No. 51. Available at: http://unctad.org/en/Docs/webdtltlb20114 en.pdf

Brooks, Mary, Thanos Pallis and Stephen Perkins. 2014. Port Investment and Container Shipping Markets - Roundtable Summary and Conclusions. OECD / International Transport Forum Discussion Paper No. 2014-03. Available at: http://www.internationaltransportforum.org/itrc/DiscussionPapers/DP201403.pdf

Containerization International. 2014. One Hundred Ports 2014 - The World's Busiest Container Terminals.

Debrie, Jean. 2012. The West African port system: global insertion and regional particularities. EchoGéo 20/2012. Available at: http://echogeo.revues.org/13070

Ecorys. 2015. Consulting Services for a Diagnostic and Analysis of Recent Trends in the Operations and Management of West African Ports. Unpublished background report prepared for the World Bank.

Farrell, Sheila. 2014. Attracting Private Finance Into African Ports. In Port Infrastructure Finance, eds. Hilde Meersman, Eddy Van de Voorde and Thierry Vanelslander, pp.181-209. Routledge Informa Law.

Grosdidier de Matons, Jean. 2012. Les Concessions Portuaires. Fondation Sefacil. Available at: http://dev.sefacil.com/sites/sefacil.com/files/Texte\%20complet\%20Concessions\%20portu aires $0 . p d f$

Harding Alan, Gylfi Palsson, and Gaël Raballand. 2007. Ports et transport maritime en Afrique de l'Ouest et du Centre: Les Défis à Relever. SSATP Working Paper No. 84F. Washington, DC: The World Bank.

Hartmannn, Olivier. 2010. Comment les pays enclavés s'articulent-ils à la mondialisation ? Ports et commerce en Afrique de l'Ouest. Afrique Contemporaine, 2010/2 No. 234, 41-58. 
Hoffmann, Jan. 2000. The potential for hub ports on the Pacific coast of South America. CEPAL Review No. 71. Available at: http://www.cepal.org/publicaciones/xml/0/20180/lcg2060i hoffmann.pdf

Juhel, Marc. 2000. Globalisation and Partnerships in Ports: Trends for the $21^{\text {st }}$ Century. Available at:http://siteresources.worldbank.org/INTPRAL/Resources/338897$1117630063267 /$ singaprt.pdf

MacWilliam, David Cal. 2013. Reducing Dwell Time to Boost Efficiency at the Port of Cotonou. Africa Trade Policy Note No. 39. Washington, DC: The World Bank.

MLTC / CATRAM. 2013. Etude de marché sur les terminaux portuaires à conteneurs en Afrique de l'Ouest et du Centre. Report prepared for the French Development Agency (AFD). Available at:

http://www.afd.fr/webdav/shared/ELEMENTS COMMUNS/pdf/MLTC CATRAM etude te rminaux conteneurs Afrique Ouest et Centre.pdf

Nathan. 2013. Logistics Cost Study of Transport Corridors in Central and West Africa. Report prepared for the World Bank. Available at: http://www.ssatp.org/sites/ssatp/files/publications/SSATP_Logistics_Cost Study_Comple te\%20with\%20annexes\%20Final\%20September\%202013.pdf

OECD. 2011. Competition in ports and port services. Competition committee roundtable on Competition in Ports and Port Services. Available at: http://www.oecd.org/regreform/sectors/48837794.pdf

OECD. 2009. Port Competition and Hinterland Connections. OECD / International Transport Forum Round Table 143. Paris: Organisation for Economic Co-operation and Development.

Palsson, Gylfi. 1998. Multiple Ports of Call versus Hub-and-Spoke Containerized Maritime Trade between West Africa and Europe. SSATP Working Paper 31. Washington DC: The World Bank.

Raballand, Gaël, Salim Refas, Monica Beuran and Gözde Isik. 2012. Why Does Cargo Spend Weeks in Sub-Saharan African Ports? Lessons from Six Countries. Washington DC: The World Bank.

Ranganathan, Rupa and Vivien Foster. 2011. ECOWAS's Infrastructure - A Regional Perspective. Policy Research Working Paper No. 5899. Washington DC: The World Bank.

TIPS. 2014. Review of regulation in the Ports Sector. Report prepared for the Centre for Competition, Regulation and Economic Development (CCRED), University of Johannesburg. Available at: http://www.tips.org.za/files/ccred-eddrecbp regulation in the ports sector - farr levin chipanda 0.pdf 
UNCTAD. 2014. Review of Maritime Transport. Geneva: UNCTAD. Available at: http://unctad.org/rmt.

UNCTAD. 2003. African ports: reform and the role of the private sector. Report UNCTAD/SDTE/TLB/5. Available at: http://unctad.org/en/docs/sdtetlb5 en.pdf

UNCTAD. 1996. Potentialities for regional port cooperation. Report UNCTAD/SDD/PORT/5. Available at: http://unctad.org/en/Docs/posddportd5.en.pdf

USAID. 2005. Emerging Challenges in Africa's Port Sector - The Congestion Pandemic and Efficiency. Available at: http://pdf.usaid.gov/pdf docs/PNADH132.pdf

World Bank. 2007. Port Reform Toolkit, $2^{\text {nd }}$ Edition. Washington, DC: The World Bank. Available online at:

http://www.ppiaf.org/sites/ppiaf.org/files/documents/toolkits/Portoolkit/toolkit.html

World Bank. 2001. Port Reform Toolkit, $1^{\text {st }}$ Edition. Washington, DC: The World Bank. 


\section{Annexes}

\section{Annex 1: Main ports and container terminals in West Africa}

\section{Dakar (Senegal)}

The Port Autonome de Dakar is the largest port of Senegal and offers transit access to several landlocked countries in the region as well as to the Gambia.

The main container terminal has been operated since January 2008 by DP World, which was awarded in the preceding year a renewable 25-year concession. Since then an expansion program has been carried out to add 8 hectares of yard space and 230 meters of quay lengths, which brought annual capacity to 600,000T TEU and became operational in November 2011. DPW controls around 80 percent of the container market in Dakar, the rest being shared between Grimaldi, Getma and small local stevedoring companies operating out of multipurpose and general cargo facilities within the port. With the expected increase of container traffic, a second phase of the extension program is planned and would involve developing by 2020 an entirely new container terminal (Port du Futur) with a potential capacity of 1.5 million TEU.

In November 2013, BAL was awarded a 25-year concession for the RoRo terminal (roll-on/rolloff), which primarily handles vehicles. The concession agreement includes the deepening of the quay from 8.5 to 10.5 meters, an extension of the quay length by 165 meters, and 3 hectares additional parking space.

\section{Banjul (the Gambia)}

The port of Banjul is the Gambia's only seaport and handles around 85 percent of the country's foreign trade. ${ }^{57}$ The port is fully run and managed by the Gambia Port Authority (GPA) on a public service basis along with various small stevedoring and storage companies. Over the years, the port has been expanded in various stages from a small jetty of 102 metres in the 1970s to currently four berths with a total quay length of 750 meters. Container ships mostly use the new jetty's two outer berths with a length of 122 meters each and a draft of 8 meters. The port's very limited equipment and handling capacity would not enable the port to handle more than current volumes. GPA has received offers of concession from international terminal operating companies in the past but has not accepted them so far.

\footnotetext{
${ }^{57}$ Given the geographical position of the Gambia, which is wholly surrounded by Senegal, and large price differentials due to disparities in trade policies, the Gambia has historically served as an "entrepot" for largely informal re-exports from the port of Banjul to Senegal and other neighboring countries. In the recent period, declining differential in import taxation and efforts by the Senegalese authorities to curb informal trade have lowered these re-exports. The higher operational and procedural efficiency of the port of Banjul vis-à-vis Dakar had also encouraged this trade, but this advantage has waned in recent years as Dakar improved and Banjul deteriorated.
} 


\section{Bissau (Guinea Bissau)}

Bissau port is fully managed by Administraçaõ dos Portos de Guiné Bissau (APGB) under a service model. The port capacity is limited by short quay length, draught of only around 7 meters as sediment builds up, and very limited equipment, with all ship-to-shore handling relying on vessels' gear. There have been talks for several years about modernizing the port through a PPP, but this has not materialized to date.

\section{Conakry (Guinea)}

The Port Autonome de Conakry is the main port in Guinea. The container terminal Conakry Terminal has been run since mid-2011 by BAL, after the newly elected authorities cancelled the initial 25-year concession awarded under military rule in 2008 to GETMA International (subsidiary of NECOTRANS). This has sparked public accusations of corruption and lawsuits. A program of expansion aimed at operating two berths and doubling yard storage capacity started at end-2012 and was inaugurated in November 2014. This added 340 meters of quay with a 13 meter draught alongside, raising the overall container terminal quay length to around 600 meters.

\section{Freetown (Sierra Leone)}

The port of Freetown is the main gateway port for Sierra Leone. The Sierra Leone Port Authority (SLPA) has been operating the port on a public-service management model until March 2011, when the 25-year concession attributed to BAL in November 2010 took effect. The initial concession agreement concerned the port's container terminal at berths 3-6. The following year, the new terminal management company Freetown Terminal concluded an agreement to manage and maintain berths 1 and 2, thus assuming operation of all the container berths. At the time of the concession, terminal capacity was estimated at 75,000 TEUs per year. The extension work completed in 2015 increased this capacity to 150,000 TEUs.

\section{Monrovia (Liberia)}

The Freeport of Monrovia is the main gateway to Liberia. The port's facilities significantly deteriorated due to the lack of upgrade and maintenance, especially during Liberia's political crisis. In March 2010, the National Port Authority of Liberia awarded a 25-year concession to rehabilitate and operate the port's container terminal to APMT, which assumed operational control in October 2010. The concession agreement included the requirement to upgrade the port within a period of three years, with a committed investment of US\$120 million. The extension of the port was officially opened in May 2013, a few months ahead of schedule. Additional investments are being carried out to upgrade yard and gate facilities in and around the terminal. 


\section{San Pedro (Cote d'Ivoire)}

The Port Autonome de San Pedro is Cote d'Ivoire's second largest port, situated $350 \mathrm{~km}$ west of Abidjan. The port handles several cargo types, with cocoa exports representing a large share of total throughput. A 15-year concession for the container terminal was awarded to MSC in September 2008, after an open competition to develop a transshipment hub with a capacity of 0.5 million TEUs per year. This has led to a significant increase of transshipment operations in the port, which grew from virtually nothing in 2009 to over 3.1 million tons in 2014. Although MSC did organize its transshipment operations from San Pedro, the opening of the new Lomé Container Terminal (cf. below) marked a shift in the long term strategy of MSC for its West Africa hub which questions the position of San Pedro in the company's operations.

\section{Abidjan (Cote d'Ivoire)}

The Port Autonome d'Abidjan is the main port of Côte d'Ivoire. It has been a transit gateway for Mali and Burkina Faso, and enjoyed some success as a transshipment hub for West Africa. The port suffered badly on both fronts due to the country's recent political crises, but started to regain its position at the regional level since 2011. The port's container terminal, Abidjan Terminal, also known as Vridi terminal, was opened in 1978 and managed by the port authority (Port Autonome d'Abidjan - PAA). In October 2003, a concession agreement was signed with BAL through its local subsidiary SETV (Société d'Exploitation du Terminal de Vridi) for a duration of 15 years, extended later to 25 years. This concession was granted without competition on a singlesource basis, triggering opposition to the process at the time, including within the Ivoirian Government. The terminal was transferred to the operator in March 2004, and expansion and modernization work started on both infrastructure and handling equipment. In July 2005, APMT acquired 40 percent of SETV from BAL.

The growth of container traffic created the possibility of developing a second container terminal (TC2) to ensure sufficient capacity to accommodate future traffic and promote intra-port competition. Although the initial intent was to prevent the operator of the first terminal to compete for the concession of the TC2, a consortium of the two SETV partners plus Bouygues was selected as preferred bidder and awarded the TC2 concession in June 2013 for a 21-year duration. The consortium offered an entry ticket of 120 million euros, an annual concession fee of 22 million euros, and committed to invest 400 million euros. The TC2 is planned to extend the port's capacity by $600,000 \mathrm{TEU}$. The new deep-sea facility will include 1,100 meters of quay length and 35 hectares of container yard, and will be capable to accommodate containerships of up to 8,000 TEUs. TC2 is scheduled to start activities in 2018.

\section{Takoradi (Ghana)}

Takoradi is Ghana's second major port and is operated under a service model by the Ghana Ports and Harbours Authority (GPHA). The port's activities are focused on bulk cargo and oil. 
Containerized traffic is limited, reaching around 50,000 TEUs in recent years. Quay length for containers reach 190 meters and draught is limited at 9 meters.

\section{Tema (Ghana)}

Tema port, located around 30km East of the capital Accra, is the leading port in Ghana and one of the main ports in the region in terms of container throughput. In August 2004, the concession for the development and operation of a container terminal was awarded for a duration of 20 years to Meridian Port Services (MPS), a partnership between the companies APMT and BAL (35 percent each) and the Ghana Ports \& Harbours Authority (GPHA) (30 percent). The creation of a container terminal required extensive demolition followed by construction work, which started respectively in June 2005 and August 2006. The terminal became partly operational in April 2007, when MPS took over container handling operations, and the construction work was completed in February 2008. At that time, the container terminal had an annual capacity of 0.5 million TEUs, which was regularly expanded by MPS, first to 750,000 TEUs, and then in June 2013, to 1 million TEUs, by acquiring quay and yard handling equipment (a US\$50 million investment) to increase berth productivity and the storage capacity of the yard (converting from reach stacker to RTG operation). Around 20 percent of container traffic is handled in multipurpose berths run by GPHA and other local operators.

In November 2014, GPHA and MPS signed a MoU for a major extension at the port of Tema, comprising four deep water berths, dredging of the access channel and a six-lane highway between Tema and Accra, with total investment estimated at US\$1.5 billion. The construction work for the extension is expected to start mid-2015, with two berths completed by October 2016, and final completion by December 2018. The final capacity of the port of Tema would increase from the current 1 million TEUs to 3.5 million TEUs.

\section{Lomé (Togo)}

The Port Autonome de Lomé in Togo is the only port along the West African coast with a natural depth of 14 meters. Container handling at the port of Lomé has been historically operated in a two-berth pier located on either side of a narrow jetty. In 2010, BAL was awarded a 35-year concession to operate the container terminal Togo Terminal. In March 2011, the extension work for Togo Terminal was launched, for an additional quay of 450 meters and 16 hectares of yard space, which became operational in October 2014.

A second concession was signed in December 2008 for the development of a new greenfield container terminal with Lomé Container Terminal (LCT). LCT is owned by Thesar Maritime Limited, a Cyprus subsidiary of Global Terminal Limited. GTL is a sister company of Terminal Investment Limited (TIL), the terminal operating arm of MSC. GTL was absorbed in 2012 by TIL, while China Merchant Holding International (CMHI) acquired a share of 50 percent in Thesar Maritime Limited (TML) in August 2012. The final shareholders of LCT are therefore now TIL/MSC and $\mathrm{CMHI}$, holding 50 percent each. The duration of the concession is 35 years, with an option 
for 10 more years. The terminal is a multi-user facility, not reserved for MSC. The Terminal entered into service in October 2014. The second phase of the development of LCT will enable it to reach a capacity of 1.65 million TEUs by end of 2016, once the 22 RTGs are delivered. As of beginning of 2015, LCT operates with 12 RTGs from Konecranes.

\section{Cotonou (Benin)}

The Port Autonome de Cotonou is the gateway port of Benin. A major share of the port's throughput corresponds to transit traffic to neighboring countries. The rehabilitation and improvement of the port's infrastructure has been funded by the Millennium Challenge Corporation (MCC) through a \$170 million grant, part of a larger grant to the Republic of Benin. The grant agreement was signed in February 2006 and entered into force in October 2006. The grant enabled the construction of 550 meters of quay and 16.5 hectares of yard at the South Wharf.

Prior to the creation of the container terminal, three stevedoring companies were licensed to handle containers: SMTC (local subsidiary of BAL), COMAN (subsidiary of Maersk Lines / APMT) and SOBEMAP (Société Béninoise de Manutentions Portuaires, a Beninese parastatal which had the monopoly over all port operations until 1998). A 25-year lease agreement was signed in 2007 with the two private companies, each of which handles nearly half of the containers. The SOBEMAP, which has a marginal market share, has had a one year renewable lease since 1998.

The operations of the container terminal were awarded through a competitive process to Benin Terminal (75 percent BAL, and 25 percent SMTC) and the concession signed in September 2009. The construction work on the new terminal started in September 2009 and was completed in April 2013, when two ship-to-shore cranes were delivered. Two additional STS cranes were delivered in January 2015. Construction work included the extension of quay length from 220 meters prior to the concession to 540 meters today.

In order to reduce congestion in Cotonou, there have been plans for several years to develop a new deep-sea port in Sèmè-Podji, some $20 \mathrm{~km}$ east of the existing port, but the project is still at the drawing phase.

\section{Badagry (Nigeria)}

In November 2012, APM Terminals launched the Badagry port project, a greenfield development about $50 \mathrm{~km}$ west of Lagos, which is adjoining a Free Trade Zone and includes a container terminal with a final estimated capacity of 2 million TEU per year. The new port aims at reducing congestion in Lagos and serving the country's Western and Northern States. The project has been promoted by a consortium led by APMT and including TIL, the Macquarie Group (an Australian fund manager), and Nigerian oil and gas companies Orlean Invest and Oando. In July 2014, this consortium signed a concession agreement with the Nigerian authorities to build and operate the terminal. Construction started in early 2015 and the expected date of completion is 2019. 


\section{Lagos (Nigeria)}

The Port of Lagos is Nigeria's largest port with two main sections for containers, Apapa and Tin Can Island. Following the Nigerian port reform in 2005, Apapa and Tincan Island ports have been divided into five terminals and unbundled into 9 facilities concessioned in 2006. The main container facilities are:

- Berths 15-18 in Apapa were concessioned to APMT for 25 years, and started operations in 2006 but not formally commissioned until June 2008. An ongoing terminal expansion is due to be completed in 2016 and involves the redevelopment of 22 a hectares container yard in the north side of the terminal with a view to increasing the terminal capacity to over 1.2 million TEUs.

- Berths 3-5 in Tin Can Island were concessioned to Tincan Island Container Terminal (TICT), a consortium of BAL and Zim shipping line, for 15 years. Zim sold its 47.5 percent stake in TICT to China Merchant Holding International (CMHI) in 2010.

- Berths 6-8 at Tin Can Island have been concessioned to Ports and Cargo Handling Services (PCHS), a subsidiary of Sifax Group, for a period of 10 years.

These three terminals together account for about 90 percent of container volumes in Lagos, while some other multipurpose berths have been concessioned for a mix of general cargo, container and RoRo operations.

Since taking over the terminals in 2006, APMT has invested US\$220 million in Lagos Apapa and BAL US\$438 million.

\section{Lekki (Nigeria)}

Lekki port is a USUS\$1.5 billion greenfield project serving a Free Trade Zone about $60 \mathrm{~km}$ east of Lagos and including a container terminal with a projected annual capacity of 2.5 million TEUs. The shareholders' agreement was signed in December 2012 between the Federal Government of Nigeria (represented by the Nigeria Ports Authority), the Lagos State Government and the Singapore Tolaram Group. A sub-concession agreement was subsequently signed with ICTSI to develop and operate the container terminal for a period of 21 years. In January 2014, ICTSI sold a 25 percent share to CMA terminal, the specialized terminal subsidiary of CMA-CGM. Construction work is scheduled to start in July 2015, for a scheduled opening early 2019. 
Annex 2: How to measure efficiency gains from terminal concessions?

Assessing the impact of private sector participation on terminal efficiency or performance requires a definition of efficiency or performance, and a consistent data series over time. The performance of a terminal operator should be evaluated in terms of the service provided to shipping lines, and thus depends on how fast a ship can complete a call. In turn, the latter involves minimizing pre-berthing delays and maximizing handling productivity once the ship is berthed. Some parameters are within control from TOC through better management techniques, or as seen earlier, through upgrade of the handling equipment. An example of better management technique is the adoption of window berthing schemes ${ }^{58}$, which, in the context of generalization of fixed day weekly services, can significantly reduce or eliminate delays and saturation. However, exogenous factors impact performances, such as the transformation of the shipping line patterns, limiting the relevance of the indicators over a long period of time. A more practical issue is that the required data for a comprehensive analysis of the evolution of performances before and after concession would be difficult to obtain.

In order to avoid this difficulty, a different definition of terminal efficiency will be used, measuring how efficient are terminal operators in utilizing their resources (i.e. the container terminal physical characteristics) in handling traffic volumes. The input-output function used to measure efficiency is derived from the theoretical capacity formula developed by UNCTAD, in which the inputs are the terminal characteristics, and the output is the terminal throughput. The method selected for the analysis is a programming (non-parametric) technique, Data Envelopment Analysis (DEA), which relates outputs to inputs by estimating efficiency directly from the data. This method has been preferred to an econometric (parametric) technique such as the Stochastic Frontier Analysis (SFA) in which assumptions are made about the relationship between inputs and outputs to estimate the parameters of a cost or a production function. The structure of container port production comprises different handling configurations and modes of operation, which makes the estimation of a functional form under SFA very difficult to apply. Programming techniques are less restricted to sample size than econometric models, and can estimate technical efficiency for both individual inputs and the overall production process. Moreover, both the multi-output nature of port production and the lack of detailed data are likely to limit the practicality and reliability of econometric methods.

Measuring port efficiency with such input-output function is common practice, and has been applied to numerous ports. Port efficiency in Africa was recently analysed with this method in

\footnotetext{
${ }^{58}$ Window berthing scheme gives priority berthing to ships arriving at the port at the scheduled time, as opposed to a first-come first-served scheme
} 
two recent papers, one concerning 16 ports in Sub-Sahara Africa ${ }^{59}$, but only for the year 2012, and a second for 6 West Africa ports ${ }^{60}$, over the period 2006 to 2012 . However, the focus of the two papers was to assess the 'waste' in resources to produce a given output, which is sound from a financial perspective, whereas from an economic perspective, what is perceived as 'waste' is actually room for growth. Considering the inertia inherent to the adjustments in container capacity (a few months for handling equipment, but up to a few years for infrastructure development) and the growth of the container volumes, some level of overcapacity is desirable. The issue then is to measure how efficient terminal operators are in managing the balance between inputs and output over time.

The dataset used in our analysis covers the 13 container terminals of the West Africa range between Dakar and Lagos, for a period of 10 years from 2004 to 2013: Dakar Container Terminal, Banjul Container and General Cargo Terminal, Conakry Container Terminal, Freetown Container Terminal, Monrovia Container Terminal, Abidjan Vridi Container Terminal, San Pedro Container and General Cargo Terminal, Tema MPS Container Terminal, Lomé Container Terminal SE2M, Cotonou Container Terminal, Apapa APMT Container Terminal, and Tin Can Island's TICT and PCHS Container Terminals. The definition of the dataset variables takes into account possible variations in handling configurations and technology, for instance by using indices that account for the variations of technological performance for Ship-to-Shore (STS) and yard-stacking cranes. STS and yard crane indices take into account the differences in handling technology and operating configuration among terminals in the sample. Each generic port configuration usually incorporates a corresponding relationship between capital and labour inputs, thus no cost or labour data is required for benchmarking operational efficiency.

The seven input variables selected for this analysis are the main factors of the terminal capacity function defined by UNCTAD: quay length, maximum draft, terminal area, Ship-to-Shore cranes, yard stacking index, internal trucks and vehicles, and the number of gate lanes. The eighth variable, for output, is the terminal throughput measured in TEUs. The choice of variables is based on a high-level aggregation of container-terminal operations with a view to utilizing available and reliable data on operational performance and ensuring homogeneity between observations. The required data was collected from both primary and secondary data sources: primary data through websites, annual reports, telephone queries and interviews during port visits; and secondary data from subscribed databases and trade journals such as Containerisation International, Cargo World, Fair-play, and World Port Focus. The information was verified and crosschecked from all these sources. The final dataset consists of annual observations for the sampled container terminals over the period 2004 to 2013, in order to include a sufficient

\footnotetext{
${ }^{59}$ Carine, A.C.F. (2015) Analyzing the Operational Efficiency of Container Ports in Sub-Saharan Africa. Open Journal of Social Sciences, 3, 10-17. http://dx.doi.org/10.4236/jss.2015.310002

60 van Dyck, G.K. (2015) Assessment of Port Efficiency in West Africa Using Data Envelopment Analysis. American Journal of Industrial and Business Management, 5, 208-218. http://dx.doi.org/10.4236/ajibm.2015.54023
} 
number of years to assess how productivity changes after the terminals have been taken over by a TOC. In a dynamic context, panel data are superior to times-series and cross-sectional data, and therefore a data point is defined as a container terminal-year, for instance Apapa-2009 or Lomé2013. The combination of 13 terminals, 8 variables, and a 10 -year timeframe has resulted into a panel dataset of 130 data points and 1,040 individual values. The software DEA-Frontier (Zhu, 2003) was used to derive solutions to both the benchmarking and productivity change analyses ${ }^{61}$.

The evolution over time of terminal efficiency for the period 2004 to 2013, covering before and after the wave of concessions, is illustrated in the following charts, ordered from west to east from Dakar to Lagos. Figure 28 covers all ports from Dakar to Abidjan, and Figure 29 all ports from Tema to Lagos. The date for the signature of the concession agreement does not necessarily coincide with the operational takeover of container handling or management of the terminal, and Table 10 provides the two dates. Overall, there is no noticeable change in the efficiency trend before and after the takeover of the container facilities by TOCs. The global trend for terminal efficiency is upward, including for the period prior to the concession, and also for Banjul, which is still operated by the public port authority. Three ports, Dakar, Abidjan, and Tema, even show erratic moves in terminal efficiency after the concession.

TABLE 16: CONCESSION SIGNATURE AND TAKEOVER OF OPERATIONS FOR CONTAINER TERMINALS IN WeSt AfRICA

\begin{tabular}{|c|c|c|c|}
\hline Port & Signature & $\begin{array}{l}\text { Operational } \\
\text { take-over }\end{array}$ & Remarks \\
\hline Dakar & 2007 & January 2008 & \\
\hline Conakry & & September 2008 & $\begin{array}{l}\text { Initial GETMA concession, Bolloré take- } \\
\text { over in March } 2011\end{array}$ \\
\hline Freetown & November 2010 & March 2011 & $\begin{array}{l}\text { Rehabilitation of the port completed after } \\
\text { the analysis period }\end{array}$ \\
\hline Monrovia & March 2010 & October 2010 & $\begin{array}{l}\text { Rehabilitation of the port completed May } \\
2013\end{array}$ \\
\hline San Pedro & September 2008 & January 2009 & \\
\hline Abidjan & December 2003 & March 2004 & \\
\hline Tema & 2004 & April 2007 & $\begin{array}{l}\text { New container terminal partly operational, } \\
\text { then fully operational in February } 2008\end{array}$ \\
\hline Lomé & 2009 & & $\begin{array}{l}\text { Togo Terminal (BAL), as the second } \\
\text { terminal, LCT, was only operational end of } \\
2014 \text {, not covered by analysis period }\end{array}$ \\
\hline Cotonou & 2009 & September 2011 & $\begin{array}{l}\text { Opening new container terminal in April } \\
2013\end{array}$ \\
\hline Lagos Apapa & 2005 & April 2006 & \\
\hline $\begin{array}{l}\text { Lagos Tin Can } \\
\text { Island }\end{array}$ & 2005 & June 2006 & \\
\hline
\end{tabular}

\footnotetext{
${ }^{61}$ All DEA and MPI analysis have been conducted by ECORYS, as preparatory work for this publication.
} 
FigURE 28: EFFICIENCY FOR PORTS IN THE RANGE DAKAR - ABIDJAN

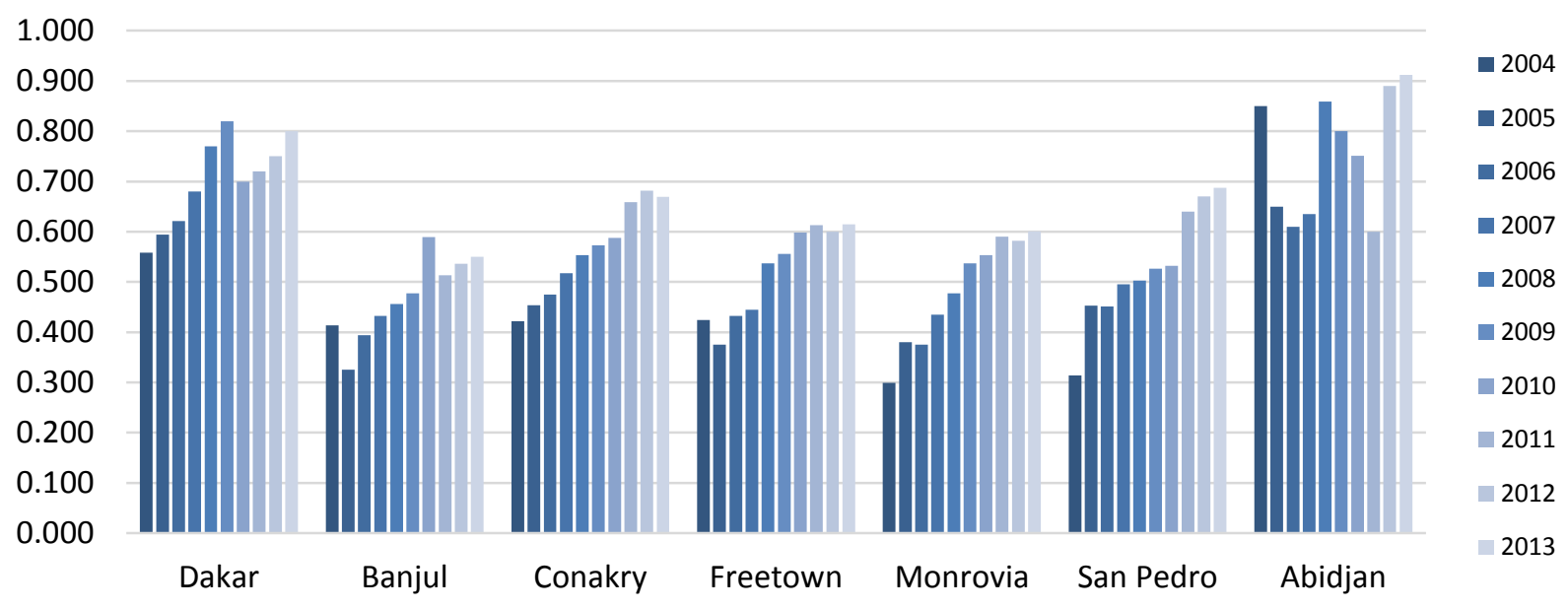

FigURE 29: EFFICIENCY FOR PORTS IN THE RANGE TEMA - LAgOS

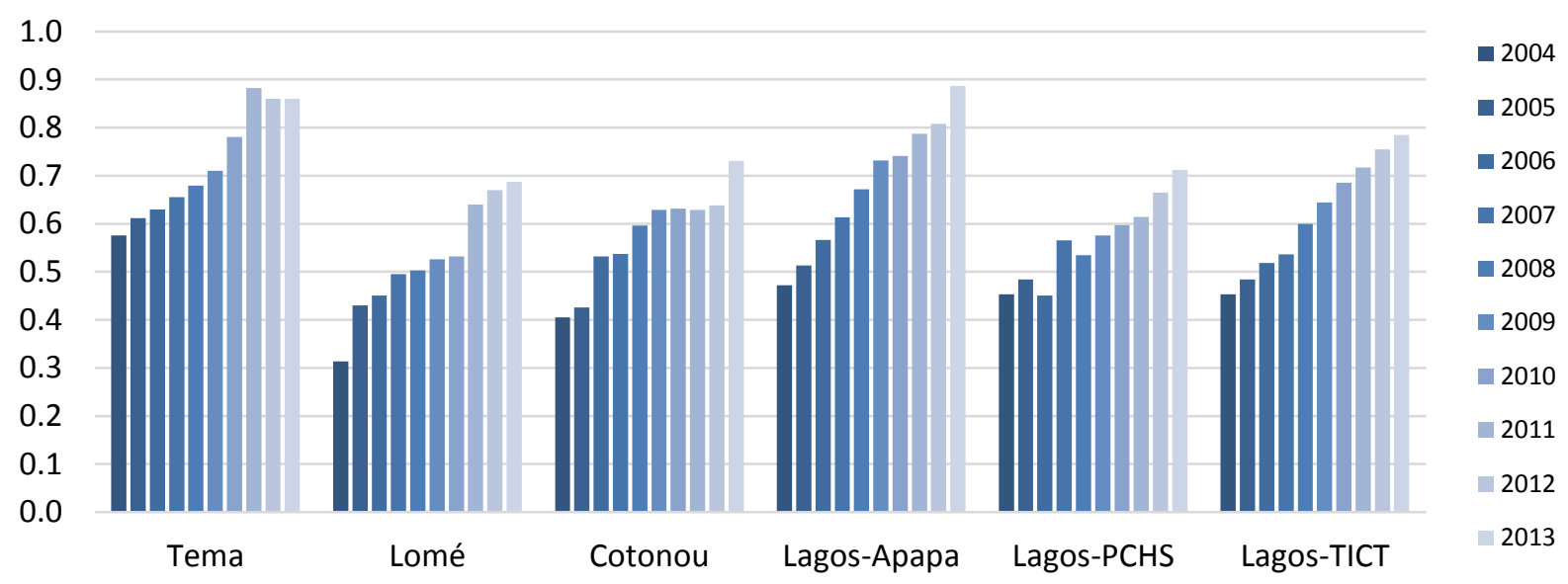

Terminal efficiency increases when throughput increases, irrespective of the mode of management. An increase in terminal throughput enables a better use of the inputs to achieve a higher level of activity. This result is largely expected. By construction, a throughput increase with constant terminal characteristics translates into a better utilization of the resources. Over the period selected for the analysis, most terminal adjustments were incremental, mostly additional handling equipment, in the form of additional ship-to-shore cranes or yard handling equipment, and very few major capacity increases in the form of new quays and yard area. Figure 30 illustrates the relationship between throughput and terminal efficiency over the period 20042013 for the main container terminals, in Dakar, Conakry, Abidjan, Tema, Lomé, Cotonou and Lagos (Apapa). Smaller ports have been omitted to avoid adding 'noise' at the lower end of this relationship. 
FIGURE 30: RELATIONSHIP BETWEEN THROUGHPUT AND TERMINAL EFFICIENCY

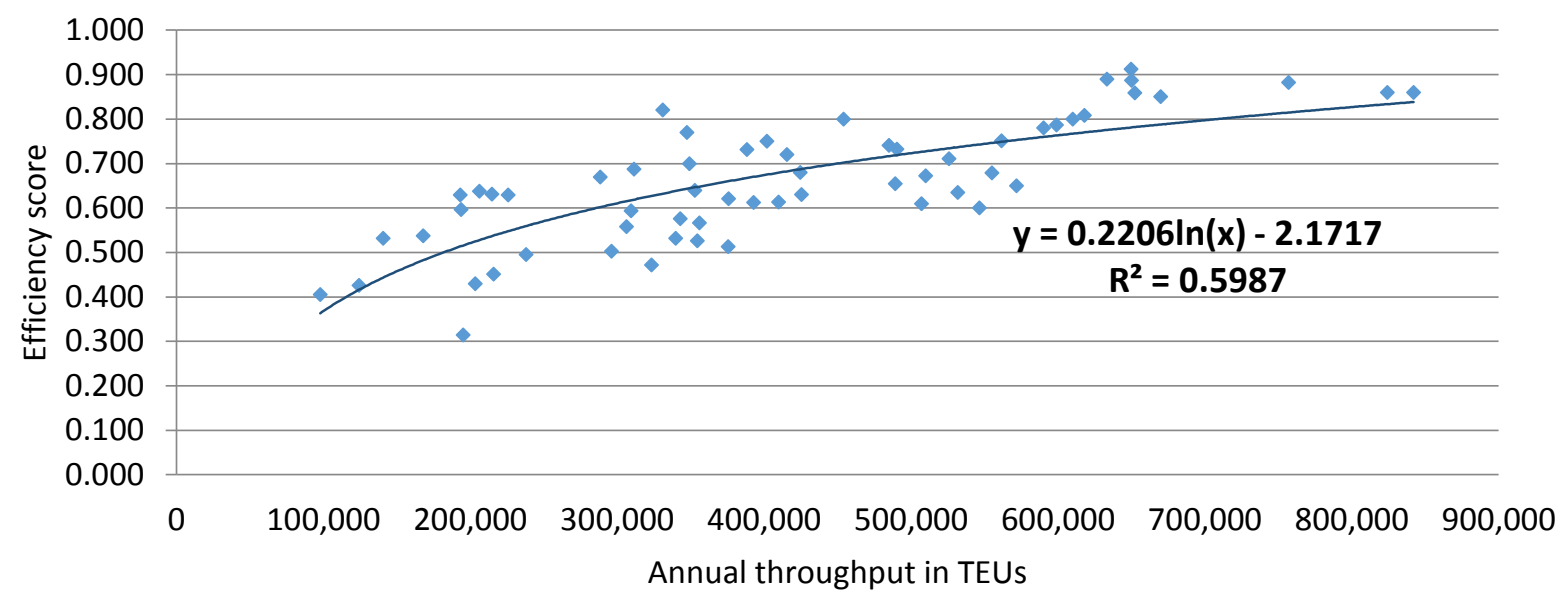

A finer analysis of efficiency gains over time, which eliminates the effect of volume, provides some evidence of improvements when TOCs took over the management of the container terminals. Using a simple model linking efficiency and throughput, illustrated in Figure 30, differences between the calculated efficiency score and the efficiency predicted by the model according to throughput have been calculated for three groups of terminals illustrated in the following graphs: Figure 31 for Abidjan and Dakar, Figure 32 for Tema, Lagos Apapa and Lomé, and Figure 33 for Conakry and Cotonou. A positive score means that efficiency is lower than it should be for the level of activity of the terminal. For all terminals, efficiency over time becomes higher than the model estimated based purely on throughput, but each one of the three group correspond to a different situation:

- In Figure 31, the evolution of the efficiency is erratic, and can be linked to substantial changes in the characteristics of the terminal, as terminal expansion in Dakar and new handling equipment in Abidjan significantly modified the ratio between input and output in the efficiency formula.

- In Figure 32, the improvement in efficiency coincides with the transfer of container terminal operations from a public sector provider to a private sector TOC in 2006 for Lagos Apapa and after 2008 when the new container terminal was fully operational for Tema. Efficiency also improved after the upgrade of the container terminal in Lomé.

- In Figure 33, there is no clear change in trend before and after the concession, and the efficiency is better than the volume would predict. In both ports, private stevedoring companies were licensed to handle containers before the concession, and the modern container facilities were completed respectively only in 2013 for Cotonou, and 2014 in Conakry. 


\section{FIGURE 31 : ABIDJAN AND DAKAR}

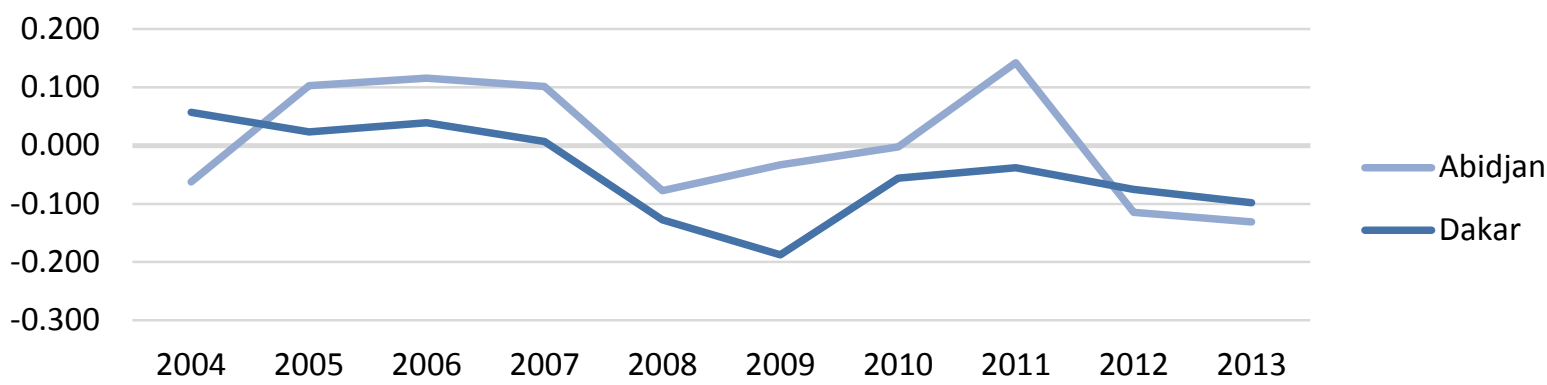

Figure 32: Tema, Lomé AND LAgos ApAPA

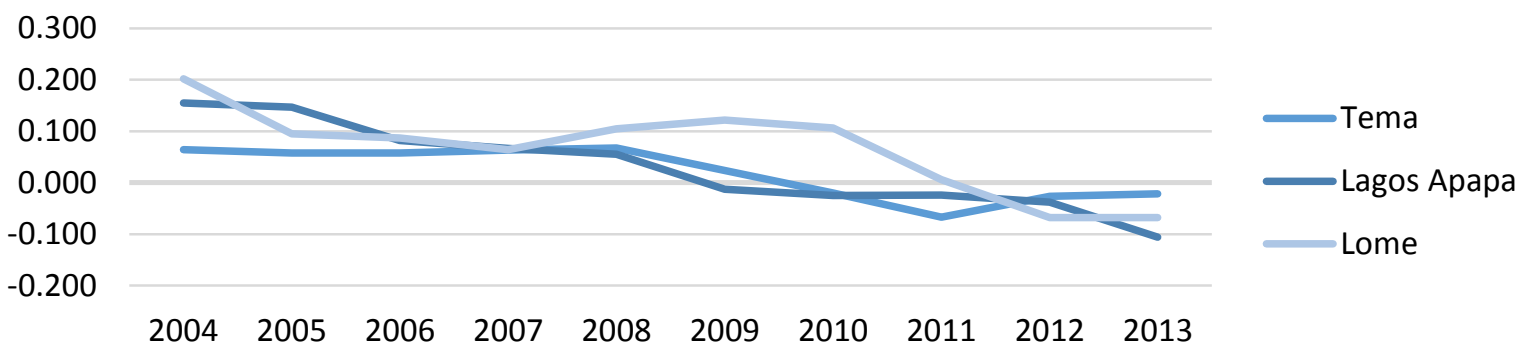

Figure 33: Conakry AND Cotonou

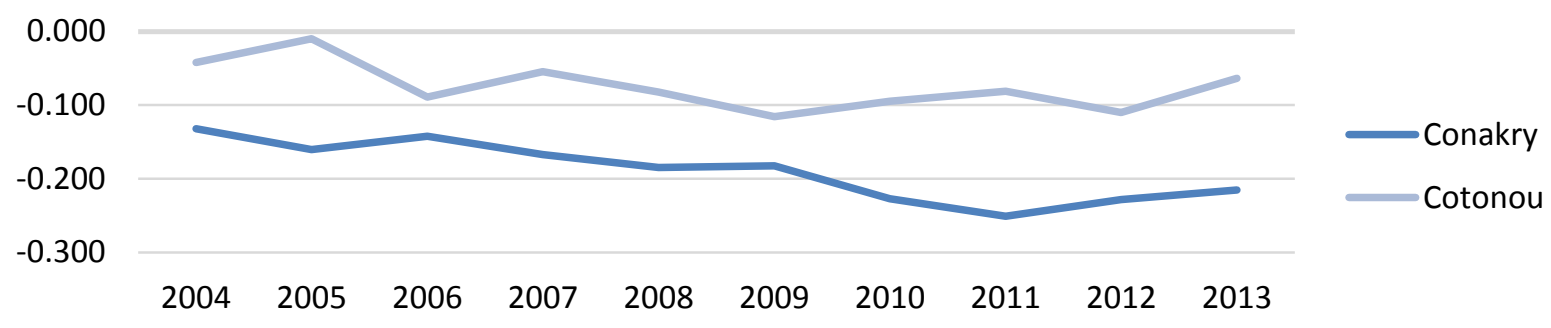


Europe has historically been West Africa's dominant trade partner, but the increasing importance of Asia from the second half of the 2000s triggered profound changes in shipping line patterns. At the beginning of the 2000s, Europe - West Africa trade was modest, less than half a million TEUs southbound and half of that northbound, split between more than a dozen ports of unequal importance. The typical service then was end-to-end, from a range of ports in Northern Europe / Mediterranean to the West Africa coastline, with ships typically calling at most ports. The double constraint of long loops (because of the number of calls) and low volumes in individual ports translated into low frequency, with a maximum of two to three calls a month when weekly calls were the norm in the shipping industry. Vessels were of modest size, due to the shallow drafts of several West Africa ports. The West Africa market was the domain of specialist carriers, dominated by Delmas shipping line (taken over by the CMA CGM group in 2005), Maersk Line (including its subsidiary Safmarine) and MCS, where multipurpose services (with ships able to carry not only containers but also breakbulk cargoes) competed with pure container ones. Trade volumes were even smaller on the Asia trade lanes, but geography gave the possibility to combine numerous trade routes. Consequently, the Asia trade lanes displayed a mix of direct services, usually a combined Asia - Southern Africa - West Africa service, and indirect services, with transshipment either in South Africa or in a Mediterranean hub port.

Shipping volumes have increased sharply over the past 10 years. The annualised capacity ${ }^{62}$ of ships serving the region rose from 2.7 million TEUs in 2005 to 9.2 million TEUs in 2014. While the number of services connecting to Europe rose from 26 (of the regional total of 37) in 2005 to 34 (of the regional total of 98) in 2014, services to Asia rose from 7 lines in 2005 to 64 in 2014. And by 2014 the largest ship deployed was 2,841 TEU on the European route but 5,336 TEU on the Asian route. The share of capacity of the big three shipping lines (Delmas then absorbed by CMA CGM, Maersk and MSC) rose from 70 percent in 2005 to 81 percent in 2014.

Despite the shift towards Asia, services on the European trade lanes continued to dominate in terms of capacity deployed for a few more years, before the liner shipping networks reorganized. Figure 34 shows the total nominal TEU annual capacity on ships deployed for service between West Africa and its main trading partners in Europe and Asia. Until 2011, it was common to relay containers between Asia and West Africa through a Mediterranean hub, thus feeding the European lines with cargo that did not originate in Europe. However, after this date, and particularly since the introduction of the WAFMAX vessels on the Asia - West Africa trade, the direct southern route became more effective, marking the decline of the European services.

\footnotetext{
62 The annualized capacity of a shipping service if defined as the average capacity of the ships deployed on the service by the number of sailing per year (for instance 52 for a weekly service)
} 


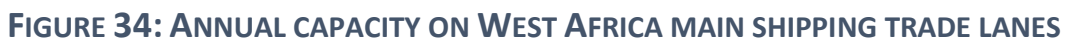

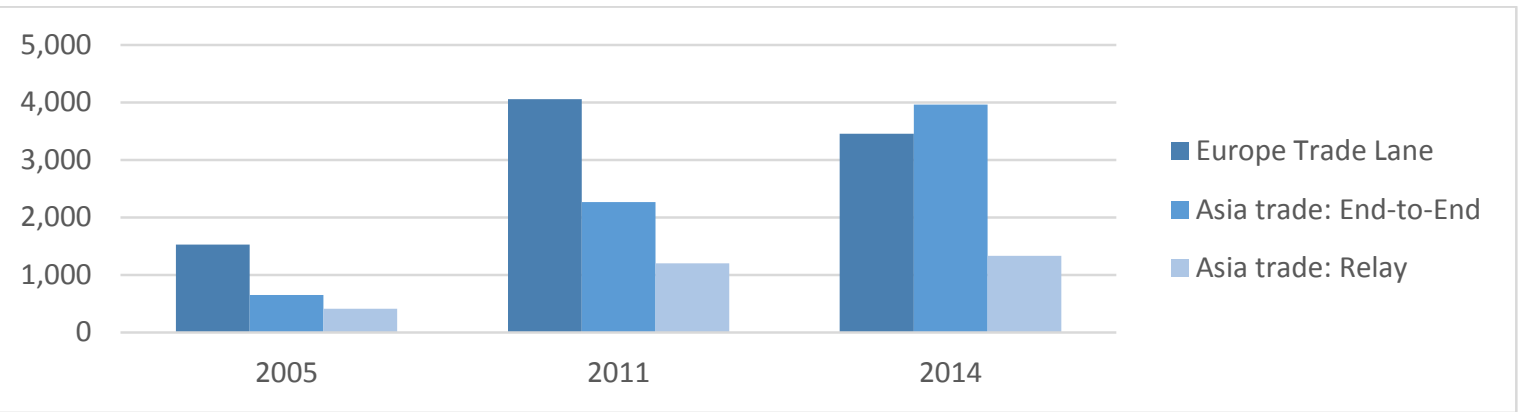

Source: ECORYS calculation based on Drewry data

The Asia - West Africa trade reached a critical mass that allowed for the deployment of larger vessels, increasing the competitiveness of the direct route over transhipment. In 2011, Maersk line received the first WAFMAX vessels in a series of 22, all delivered between March 2011 and February 2013. These vessels were purpose-built for the Asia - West Africa trade, taking into account the access limitation of the main West Africa ports. The ships are $249.1 \mathrm{~m}$, with a $37.4 \mathrm{~m}$ long beam, a $13.5 \mathrm{~m}$ draft and a nominal capacity of 4,500 TEUs. According to analysis by Alphaliner ${ }^{63}$, the largest vessel deployed on the trade increased in size by 87 percent between 2009 and 2014. The movement accelerated in the last years, largely triggered by the launch of MSC's West Africa Express service from Asia in April 2014 to replace its relay operation via Valencia, with 3,950 TEUs ships. Maersk Line and CMA-CGM followed with fleet upgrades. When MSC replaced its ships with 6,000+ TEUs in October, the rest of the shipping lines followed with size increases. Hapag Lloyd, China Shipping and NYK scrapped their joint service to switch partners, HL and NYK with Gold Star used 3,400 TEUs ships, and China Shipping with PIL used 4,000 TEUs vessels whereas the previous versions of the services were using 2,600 TEUs ships.

FigUre 35: EVolUtion of SHIPPING SERVICES ON AsIA - WeSt AfRICA tRADE
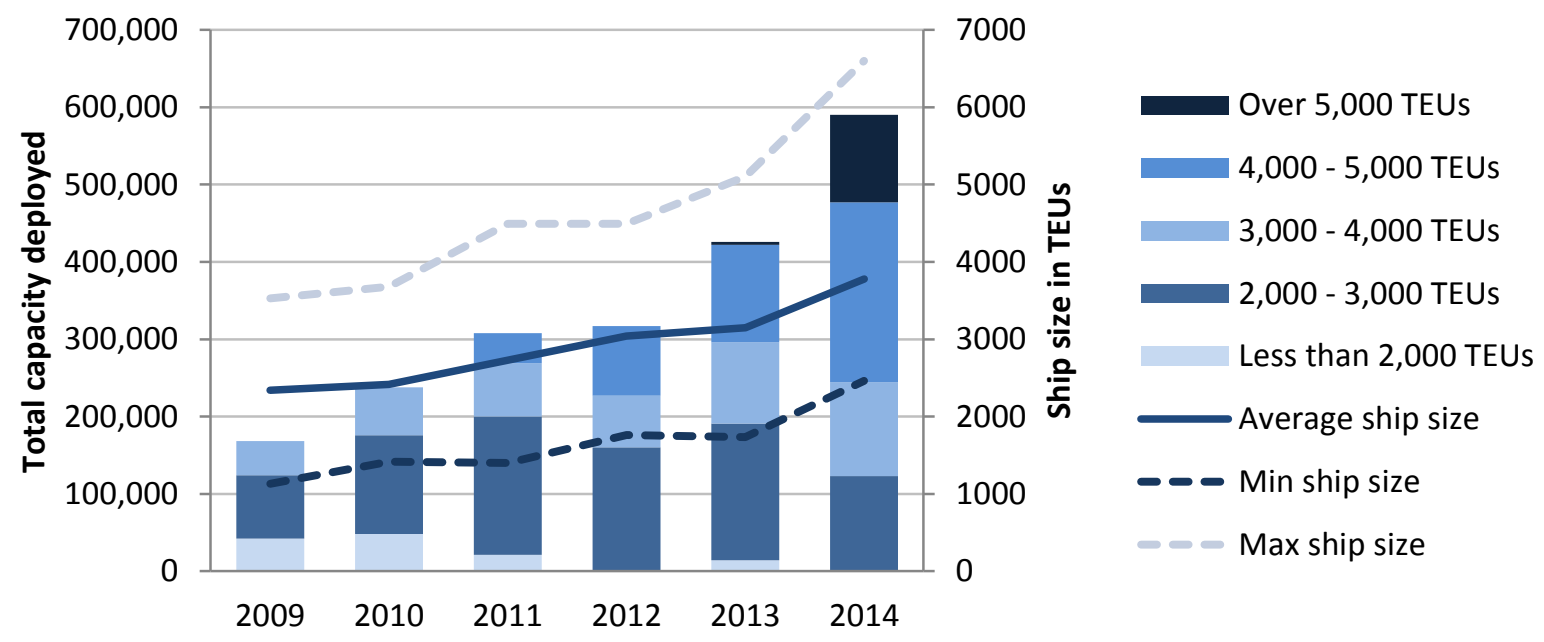

Source: Alphaliner

${ }^{63}$ Alphaliner Newsletter Volume 2014, issue 45. 
With large vessels and long loops on the Asia trade lane, the number of port calls in West Africa needed to be reduced, paving the way for the development of transshipment within the region. The distance between Asia and West Africa on the southern route means that maintaining a weekly service requires usually 11 to 12 ships, to accommodate intermediate ports of call, for instance in Southern Africa or in the Indian Ocean. In order to avoid expanding the required fleet to maintain a weekly service, ports are dropped, retaining only major ports on the main schedule and developing feeder services for the others. The case of the MSC express service is pushing this logic to its limit, with only one port of call in West Africa, Lomé, allowing MSC to maintain a weekly service with 10 ships only, but with an increased capacity ranging from 6,000 to 6,500 TEUs. A series of feeder services provides the connections to the rest of West Africa: a shuttle service to Lagos Apapa and Tin Can, one to Cotonou, one to Tema and Abidjan, one to Takoradi, one to Freetown and Monrovia, and two others to Central Africa.

Larger volumes on the West Africa trades and modern container terminals equipped with overpanamax STS and deeper draft contributed to the reducing the perception of the region as a niche market, reserved to operators with a deep knowledge of the region gained over a long past involvement. Although Maersk, CMA CGM and MSC continue to dominate the West Africa trades, many other lines joined the trade, and the competitive pressure on the freight rates increased as larger vessels with a lower unit cost per TEU were deployed. The Shanghai Shipping Exchange is publishing a freight index on the main Chinese trade lanes: on the West Africa trade lane, the reference port for that index is Lagos. In 2010, the index was close to $\$ 2,500$, decreasing to $\$ 1,800$ mid-2014, and below $\$ 1,300$ since the beginning of 2016. On the European trades, sample rates from a shipping line ${ }^{64}$ show an even more important decrease, from around \$1,200 for a 20' container from Antwerp to West Africa in 2012, to \$400 in 2016.

Figure 36: Evolution of Freight Rates (Shanghai Container Freight Index)

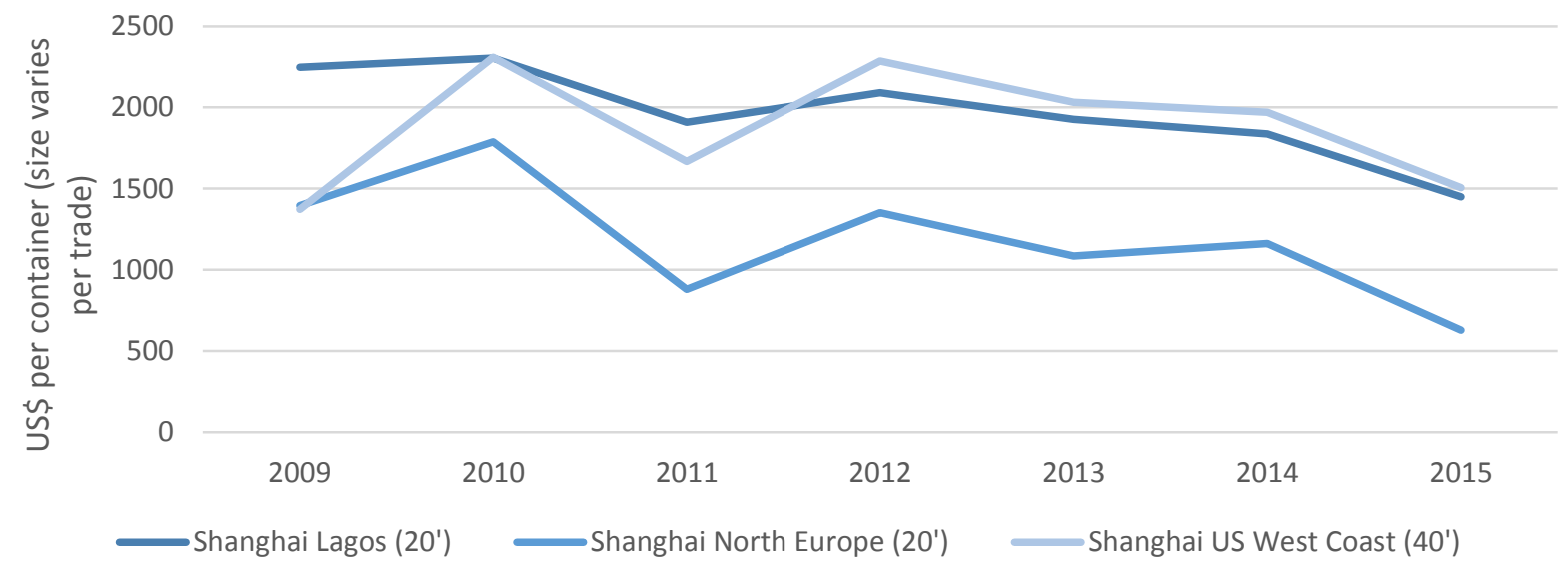

Source: UNCTAD Review of Maritime Transport 2016

${ }^{64}$ Anonymous data provided by BAL 
Annex 4: Nigeria Terminal Concessions

TABle 17: NIGERIA TeRMinal ConCESSIONS

\begin{tabular}{|c|c|c|c|c|c|c|}
\hline Transaction & Terminal operator & Participation & Port & $\begin{array}{l}\text { Concession } \\
\text { rounds }\end{array}$ & Duration & Amount (US\$̦M) \\
\hline $\begin{array}{l}\text { Apapa } \\
\text { Container } \\
\text { Terminal }\end{array}$ & $\begin{array}{l}\text { A.P. Moller Apapa } \\
\text { Terminal Ltd. }\end{array}$ & $\begin{array}{l}\text { APM Terminals as Lead with local } \\
\text { participation }\end{array}$ & $\begin{array}{l}\text { Lagos Port } \\
\text { Complex }\end{array}$ & Round 1 & 25 & $1,061.14$ \\
\hline $\begin{array}{l}\text { Apapa } \\
\text { Terminal 'A' }\end{array}$ & $\begin{array}{l}\text { Apapa Bulk } \\
\text { Terminal Ltd. }\end{array}$ & $\begin{array}{l}\text { Local lead with Atlantic Bulk Carriers } \\
\text { Mgt. from Greece as Technical Partners }\end{array}$ & $\begin{array}{l}\text { Lagos Port } \\
\text { Complex }\end{array}$ & Direct negotiation & 25 & 18.1 \\
\hline $\begin{array}{l}\text { Apapa } \\
\text { Terminal 'B' }\end{array}$ & $\begin{array}{l}\text { Apapa Bulk } \\
\text { Terminal Ltd. }\end{array}$ & $\begin{array}{l}\text { Local lead with Atlantic Bulk Carriers } \\
\text { Mgt. from Greece as Technical Partners }\end{array}$ & $\begin{array}{l}\text { Lagos Port } \\
\text { Complex }\end{array}$ & Direct negotiation & 25 & 12.07 \\
\hline $\begin{array}{l}\text { Apapa } \\
\text { Terminal 'C' }\end{array}$ & $\begin{array}{l}\text { ENL Consortium } \\
\text { Limited }\end{array}$ & $\begin{array}{l}\text { Local lead with Dublin Port Company } \\
\text { and ICIL from Ireland and Civil \& } \\
\text { Coastal from South Africa }\end{array}$ & $\begin{array}{l}\text { Lagos Port } \\
\text { Complex }\end{array}$ & Round 1 & 10 & 13.58 \\
\hline $\begin{array}{l}\text { Apapa } \\
\text { Terminal 'D' }\end{array}$ & $\begin{array}{l}\text { ENL Consortium } \\
\text { Limited }\end{array}$ & $\begin{array}{l}\text { Local lead with Dublin Port Company } \\
\text { and ICIL from Ireland and Civil \& } \\
\text { Coastal from South Africa }\end{array}$ & $\begin{array}{l}\text { Lagos Port } \\
\text { Complex }\end{array}$ & Round 1 & 10 & 12.25 \\
\hline $\begin{array}{l}\text { Apapa } \\
\text { Terminal 'E' }\end{array}$ & $\begin{array}{l}\text { Greenview Dev. } \\
\text { Nigeria Limited }\end{array}$ & Local Dangote Group & $\begin{array}{l}\text { Lagos Port } \\
\text { Complex }\end{array}$ & Direct negotiation & 25 & 25.07 \\
\hline $\begin{array}{l}\text { Port } \\
\text { Harcourt 'A' }\end{array}$ & $\begin{array}{l}\text { Ports \& Terminal } \\
\text { Operators Nig Ltd }\end{array}$ & Local Lead with P\&O Nedlloyd & $\begin{array}{l}\text { Port } \\
\text { Harcourt }\end{array}$ & Round 2 & 15 & 90.81 \\
\hline $\begin{array}{l}\text { Port } \\
\text { Harcourt 'B' }\end{array}$ & $\begin{array}{l}\text { BUA International } \\
\text { Limited }\end{array}$ & $\begin{array}{l}\text { Local Lead with Apec Antwerp Port } \\
\text { consultants }\end{array}$ & $\begin{array}{l}\text { Port } \\
\text { Harcourt }\end{array}$ & Round 2 & 20 & 12.36 \\
\hline $\begin{array}{l}\text { Tin Can } \\
\text { Island Port } \\
\text { 'A' }\end{array}$ & $\begin{array}{l}\text { Josepdam \& Sons } \\
\text { Ltd }\end{array}$ & $\begin{array}{l}\text { Local Lead with Techserve and South } \\
\text { African Sugar Company from South } \\
\text { Africa }\end{array}$ & $\begin{array}{l}\text { Tin Can } \\
\text { Island } \\
\text { Port }\end{array}$ & Round 3 & 10 & 14.05 \\
\hline $\begin{array}{l}\text { Tin Can } \\
\text { Island Port } \\
\text { 'B' }\end{array}$ & $\begin{array}{l}\text { Tin Can Island } \\
\text { Container } \\
\text { Terminal Ltd }\end{array}$ & $\begin{array}{l}\text { Bolloré Group as Lead with Zim } \\
\text { Integrated Shipping Services and Local } \\
\text { participation }\end{array}$ & $\begin{array}{l}\text { Tin Can } \\
\text { Island } \\
\text { Port }\end{array}$ & Round 3 & 15 & 83.31 \\
\hline $\begin{array}{l}\text { Tin Can } \\
\text { Island Port } \\
\text { 'C' }\end{array}$ & Sifax Nig Ltd & local firms as lead with Bremenports & $\begin{array}{l}\text { Tin Can } \\
\text { Island } \\
\text { Port }\end{array}$ & Round 3 & 10 & 104.42 \\
\hline
\end{tabular}




\begin{tabular}{|c|c|c|c|c|c|c|}
\hline $\begin{array}{l}\text { Tin Can } \\
\text { Island Port } \\
\text { RoRo }\end{array}$ & $\begin{array}{l}\text { Comet } \\
\text { Consortium }\end{array}$ & Local Lead with Eurogate Int. and MSC & $\begin{array}{l}\text { Tin Can } \\
\text { Island } \\
\text { Port }\end{array}$ & Round 3 & 15 & 86.63 \\
\hline Lilypond ICD & A.P Moller & $\begin{array}{l}\text { APM Terminals as Lead with local } \\
\text { participation }\end{array}$ & $\begin{array}{l}\text { Lagos Port } \\
\text { Complex }\end{array}$ & Round 3 & 10 & 9.65 \\
\hline Onne FLT A & $\begin{array}{l}\text { Brawals Nigeria } \\
\text { Limited }\end{array}$ & Local Group & Onne Port & Direct negotiation & 25 & 16.66 \\
\hline Onne FLT B & Intels Nig Ltd & Local Group with International partners & Onne Port & Direct negotiation & 25 & 29.06 \\
\hline Onne FOT A & Intels Nig Ltd & Local Group with International partners & Onne Port & Direct negotiation & 25 & 38.13 \\
\hline $\begin{array}{l}\text { Calabar Old } \\
\text { Port }\end{array}$ & Addax Limited & International Company with local base & $\begin{array}{l}\text { Calabar } \\
\text { Old Port }\end{array}$ & Direct negotiation & 25 & 2.01 \\
\hline $\begin{array}{l}\text { Calabar New } \\
\text { 'A' }\end{array}$ & Intels Nig Ltd & Local Group with International partners & $\begin{array}{l}\text { Calabar } \\
\text { New Port }\end{array}$ & Direct negotiation & 25 & 2.51 \\
\hline $\begin{array}{l}\text { Calabar New } \\
\text { 'B' }\end{array}$ & Ecomarine Ltd. & West African Group & $\begin{array}{l}\text { Calabar } \\
\text { New Port }\end{array}$ & Round 4 & 10 & 30.03 \\
\hline Warri Old 'A' & Intels Nig Ltd & Local Group with International partners & $\begin{array}{l}\text { Warri Old } \\
\text { Port }\end{array}$ & Direct negotiation & 25 & 2.55 \\
\hline Warri Old 'B' & $\begin{array}{l}\text { Associate } \\
\text { Maritime Services }\end{array}$ & Local Group with International partners & $\begin{array}{l}\text { Warri Old } \\
\text { Port }\end{array}$ & Round 4 & 10 & 1.9 \\
\hline Warri Old 'C' & $\begin{array}{l}\text { Julius Berger } \\
\text { Nigeria Limited }\end{array}$ & $\begin{array}{l}\text { Local Sub. of an Int. firm with } \\
\text { Bremenports }\end{array}$ & $\begin{array}{l}\text { Warri Old } \\
\text { Port }\end{array}$ & Direct negotiation & 25 & 5.5 \\
\hline $\begin{array}{l}\text { Warri New } \\
\text { 'A' }\end{array}$ & $\begin{array}{l}\text { Global } \\
\text { Infrastructure } \\
\text { Limited }\end{array}$ & An Indian Group based in UK & $\begin{array}{l}\text { Warri } \\
\text { New Port }\end{array}$ & Direct negotiation & 25 & 2 \\
\hline $\begin{array}{l}\text { Warri New } \\
\text { 'B' }\end{array}$ & Intels Nig Ltd & Local Group with International partners & $\begin{array}{l}\text { Warri } \\
\text { New Port }\end{array}$ & Direct negotiation & 25 & 6.6 \\
\hline Koko Port & $\begin{array}{l}\text { Gulftainer Bel } \\
\text { consortium }\end{array}$ & Local Group with International partners & Koko Port & Round 4 & 10 & 2.9 \\
\hline
\end{tabular}


Annex 5: Characteristics of the main West African container terminals

TABle 18: CHARACTERISTICS OF tHe MAIN WeSt African CONTAINER teRMINALS

\begin{tabular}{|c|c|c|c|c|c|c|c|c|c|c|}
\hline \multirow{2}{*}{ Terminal } & \multirow{2}{*}{$\begin{array}{c}\text { Quay } \\
\text { length } \\
\text { (meters) }\end{array}$} & \multirow{2}{*}{$\begin{array}{c}\text { Draft } \\
\text { (meters) }\end{array}$} & \multicolumn{4}{|c|}{ Handling equipment } & \multicolumn{2}{|c|}{ Yard } & \multicolumn{2}{|c|}{$\begin{array}{l}\text { Annual capacity } \\
\text { (kTEUs) }\end{array}$} \\
\hline & & & STS & RTG & $\begin{array}{l}\text { Mobile } \\
\text { crane }\end{array}$ & $\begin{array}{l}\text { Reach } \\
\text { stacker }\end{array}$ & Area (ha) & $\begin{array}{l}\text { Capacity } \\
\text { (kTEUs) }\end{array}$ & Current & Planned \\
\hline Dakar & 660 & 13.5 & 4 & 10 & 4 & 15 & $\begin{array}{l}24(+2 \\
\text { ICDs }\end{array}$ & & 600 & \\
\hline $\begin{array}{l}\text { Dakar - Port du } \\
\text { Futur (project) }\end{array}$ & 1,150 & 15 & & & & & & & & 1,500 \\
\hline Banjul & 600 & $10.5-13$ & None & None & 2 & 6 & 20 & 15 & & \\
\hline Bissau & & 7 & None & None & & & & & & \\
\hline Conakry & 600 & 13 & 5 (to come) & 5 & 2 & 12 & 23 & 15 & 150 & \\
\hline Freetown & 707 & 10 & 2 & None & 2 & 9 & & 4.8 & 150 & \\
\hline Monrovia & 600 & $7.5-11$ & None & None & None & & 13 & & 75 & \\
\hline San Pedro & & 15 & & & 2 & 11 & $\begin{array}{c}5(23 \\
\text { planned) }\end{array}$ & & 330 & 720 \\
\hline Abidjan - SETV & 1,000 & $11.5-12.5$ & 6 & 16 & 3 & 12 & 34 & 20 & 1,500 & \\
\hline $\begin{array}{l}\text { Abidjan - TC2 } \\
\text { (project) }\end{array}$ & 1,100 & 18 & 9 & 26 & & & 37.5 & & 2,100 & \\
\hline Takoradi & 190 & 9 & & & & & 28 & 20 & 200 & \\
\hline Tema & 575 & 11.5 & 5 & 13 & 2 & 23 & $\begin{array}{l}10(+3 \\
\text { ICDs) }\end{array}$ & 20 & 1,000 & 3,500 \\
\hline $\begin{array}{l}\text { Lomé - Togo } \\
\text { Terminal }\end{array}$ & 920 & 15 & $\begin{array}{c}2(5 \\
\text { planned) }\end{array}$ & 4 & 6 & 19 & 38 & 10 & 350 & 1,200 \\
\hline
\end{tabular}




\begin{tabular}{|c|c|c|c|c|c|c|c|c|c|c|}
\hline Lomé - LCT & 1,050 & 16.6 & $\begin{array}{c}6(12 \\
\text { planned) }\end{array}$ & $\begin{array}{c}12(22 \\
\text { planned } \\
)\end{array}$ & & & 54 & & & 2,200 \\
\hline $\begin{array}{l}\text { Cotonou - Bénin } \\
\text { Terminal }\end{array}$ & 540 & $13.5-15$ & 4 & 10 & 2 & 15 & $\begin{array}{c}20(+20 \\
\text { planned) }\end{array}$ & 15 & & \\
\hline $\begin{array}{l}\text { Badagry } \\
\text { (project) }\end{array}$ & $\begin{array}{c}775 \\
(2,600 \\
\text { final } \\
\text { phase })\end{array}$ & $14.5-17$ & & & & & $\begin{array}{c}46 \text { (149 } \\
\text { final } \\
\text { phase) }\end{array}$ & & & $\begin{array}{c}1,800 \text { to } \\
2,000\end{array}$ \\
\hline Lagos - Apapa & 1,005 & 12.5 & 7 & $\begin{array}{c}10(14 \\
\text { planned } \\
\text { ) }\end{array}$ & & & 55 & 32 & 1,000 & \\
\hline Lagos - TICT & 770 & 11.5 & 1 & 12 & 9 & 23 & 24 & 20 & 400 & \\
\hline Lekki (project) & 1,200 & $14-16.5$ & 14 & & & & 66 & & & 2,500 \\
\hline
\end{tabular}


Annex 6: Tables for container traffic forecast

TABle 19: EVolution Of TRAFFiC AT THE MAIN WESt AfRICAN PORTS (1996 - 2006 - 2011) IN 000S TEUS

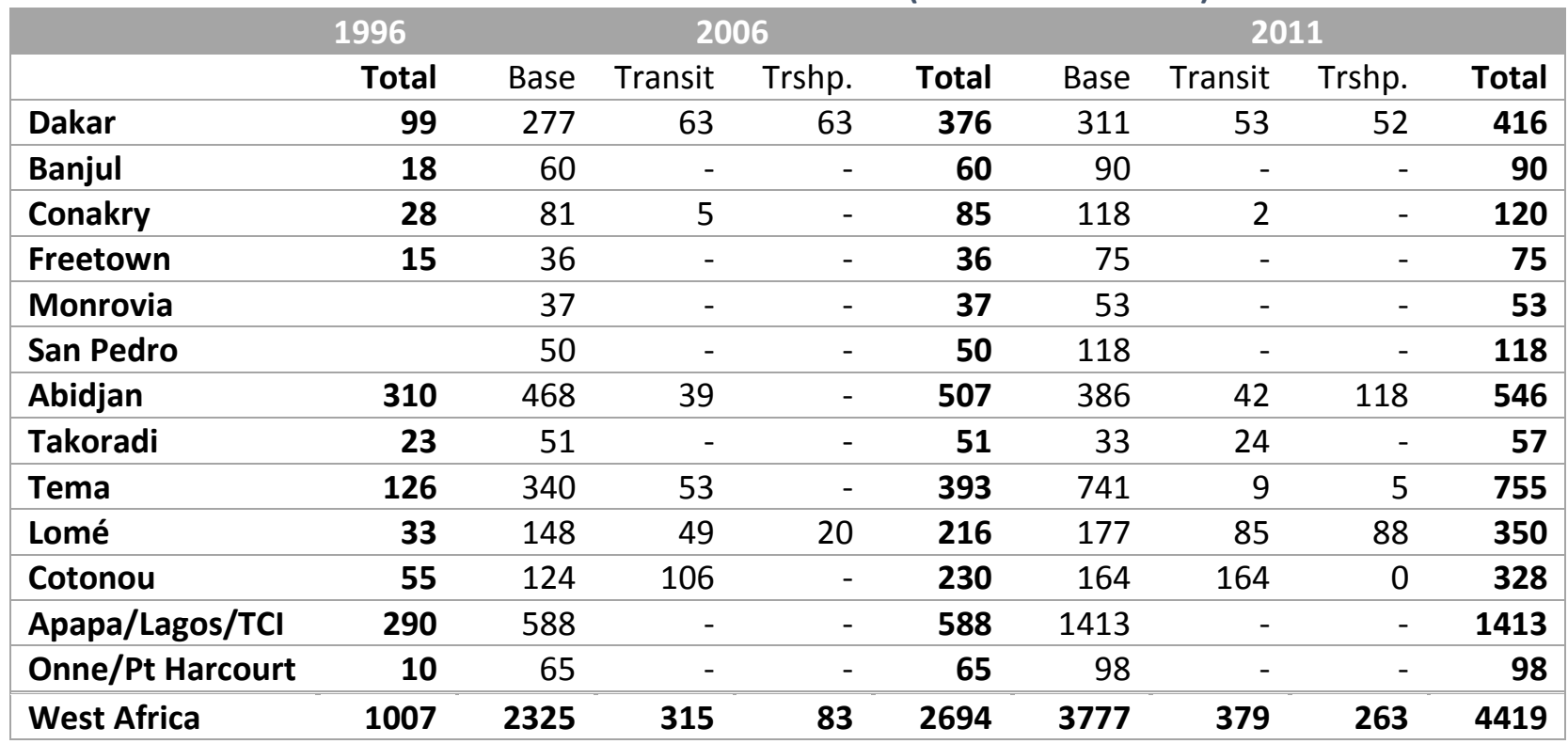

TABLE 20: GDP AND GDP GROWTH

\begin{tabular}{|lrrrrrrrrr|}
\hline Country & 1996 & 2006 & 2011 & 2017 & 2020 & $96 / 06$ & $06 / 11$ & $11 / 17$ & $17 / 20$ \\
\hline Benin & 2.4 & 5.1 & 7.8 & 9.6 & 12.1 & $8.1 \%$ & $8.7 \%$ & $3.5 \%$ & $7.9 \%$ \\
\hline Cabkina Faso & 2.6 & 5.8 & 10.7 & 13.1 & 16.8 & $8.4 \%$ & $13.0 \%$ & $3.4 \%$ & $8.7 \%$ \\
\hline Côte d'Ivoire & 12.1 & 17.8 & 25.7 & 38.4 & 51.5 & $3.9 \%$ & $7.6 \%$ & $6.9 \%$ & $10.3 \%$ \\
\hline Ghana & 11.3 & 20.4 & 39.6 & 46.6 & 60.2 & $6.1 \%$ & $14.2 \%$ & $2.8 \%$ & $8.9 \%$ \\
\hline Guinea & 3.9 & 2.9 & 4.5 & 6.9 & 8.3 & $-2.8 \%$ & $9.1 \%$ & $7.4 \%$ & $6.4 \%$ \\
\hline Guinea-Bissau & 0.4 & 0.6 & 1.1 & 1.2 & 1.6 & $3.1 \%$ & $13.3 \%$ & $1.9 \%$ & $7.9 \%$ \\
\hline Liberia (*) & 0.6 & 0.8 & 1.5 & 2.3 & 3.0 & $4.3 \%$ & $15.3 \%$ & $7.2 \%$ & $9.3 \%$ \\
\hline Mali & 3.4 & 6.9 & 13.0 & 15.2 & 18.1 & $7.3 \%$ & $13.5 \%$ & $2.6 \%$ & $6.1 \%$ \\
\hline Niger & 1.9 & 3.7 & 6.4 & 8.1 & 10.5 & $6.9 \%$ & $11.9 \%$ & $4.1 \%$ & $8.9 \%$ \\
\hline Nigeria & 172.7 & 222.8 & 414.1 & 413.7 & 482.7 & $2.6 \%$ & $13.2 \%$ & $0.0 \%$ & $5.3 \%$ \\
\hline Senegal & 5.1 & 9.4 & 14.4 & 16.2 & 21.2 & $6.3 \%$ & $9.0 \%$ & $1.7 \%$ & $9.2 \%$ \\
\hline Sierra Leone & 1.3 & 1.9 & 2.9 & 4.4 & 5.5 & $3.8 \%$ & $9.2 \%$ & $6.0 \%$ & $6.6 \%$ \\
\hline The Gambia & 0.6 & 0.7 & 0.9 & 0.8 & 1.0 & $1.4 \%$ & $6.5 \%$ & $-1.2 \%$ & $6.9 \%$ \\
\hline Togo & 1.6 & 2.2 & 3.8 & 4.9 & 6.1 & $3.5 \%$ & $11.1 \%$ & $4.0 \%$ & $7.9 \%$ \\
\hline Grand Total & $\mathbf{2 2 0 . 3}$ & $\mathbf{3 0 2 . 1}$ & $\mathbf{5 4 8 . 3}$ & $\mathbf{5 8 3 . 3}$ & $\mathbf{7 0 0 . 9}$ & $\mathbf{4 . 0 \%}$ & $\mathbf{1 3 . 2 \%}$ & $\mathbf{6 . 0 \%}$ & $\mathbf{6 . 4 \%}$ \\
\hline
\end{tabular}

Note $(*)$ : for Liberia, the first recorded value is 2000 . GDP growth calculated on the period 2000 to 2006

Source: IMF World Economic Outlook Database October 2016 (data code NGDPD) 
TABLE 21: CONTAINER GROWTH TO GDP GROWTH ELASTICITY

\begin{tabular}{|lrrr|}
\hline Port & Period 1996 to 2006 & Period 2006 to 2011 & Period 1996 to 2011 \\
\hline Banjul & 1.71 & 0.26 & 1.10 \\
\hline Conakry & 9.26 & 1.30 & 3.70 \\
\hline Freetown & -3.96 & 0.90 & 11.44 \\
\hline Monrovia & 2.40 & 1.71 & 2.02 \\
\hline San Pedro & & 0.49 & \\
\hline Abidjan & & 2.55 & 0.29 \\
\hline Takoradi & 1.07 & -0.51 & 0.28 \\
\hline Tema & 1.36 & -0.59 & 1.44 \\
\hline Lomé & 1.71 & 1.19 & 1.99 \\
\hline Cotonou & 4.68 & 0.33 & 0.91 \\
\hline Lagos Apapa / Tin Can Island & 1.05 & 0.66 & 1.62 \\
\hline Onne / Port Harcourt & 2.08 & 1.37 & 2.38 \\
\hline West Africa coast & 5.85 & 0.61 & $\mathbf{1 . 6 5}$ \\
\hline
\end{tabular}

Source: author's calculation based on the two previous tables

Note: Container growth excludes transit and transhipment for individual ports. GDP growth for the West Africa coast includes all 15 ECOWAS countries, and includes transit traffic for ports, but excludes transhipment. 